UNIVERSIDADE DE SÃO PAULO

INSTITUTO DE QUÍMICA

\title{
TOXICIDADE DE OXIGÊNIO EM PORTADORES \\ DE PORFIRIA AGUDA INTERMITENTE E EM INDIVÍDUOS EXPOSTOS A ALTOS NÍVEIS DE POLUIÇÃO
}

MARISA HELENA GENNARI DE MEDEIROS

DISSERTAÇÃO DE MESTRADO

Orientador: Prof. Dr. Etelvino José Henriques Bechara 
Aos meus pais,

Nilo Mourão de Medeiros e Wanda Genari de Medeiros, pelo amor, trabalho e sentido de liberdade. 
Ao Prof. Dr. Etelvino José Henriques Bechara, pela orientação segura e eficiente. 
Ao Paulo Victor, pelo afeto e compreensão 
Um agradecimento especial ao

Dr. Paulo E. Marchiori

pela colaboração e participação entusiástica na discussão e interpretação dos resultados. 
AGRADECIMENTOS

- ao Prof. G. Cilento pela colaboração durante a elaboração des te trabalho.

- ao Luiz Henrique (Lique) por ter dividido comigo com amizade e paciēncia todos os momentos e constante apoio e interesse com que acompanhou o desenvolvimento deste trabalho.

- ao Iguatemy, Adilson e Edson pelo auxílio na coleta das amostras de sangue.

- à Anã, Dinha, Lilian, Edy, Roberto, Sérgio, Alberto, Wilson, Shimizu e demais amigos, pela doação de sangue e o carinho de todos os dias.

- à Dona Jacyra e à Lydia, pela amizade.

- à Nazira, pelo carinho e pelo trabalho de datilografia.

- à Prefeitura do Município de Cubatão, pelo apoio na coleta das amostras de sangue na região de Vila Parisi.

- à Dra. Maria do Socorro Onofré, médica do Pronto Socorro de Vila Parisi, pela contribuição durante a coleta de sangue.

- aos alunos da Escola de Formação e Aperfeiçoamento de Soldados da Polícia Militar, dirigida pelo Comandante Cel. P.M. olandim Trielli Pereira, pela doação de amostras de sangue.

- à Fundação de Amparo à Peśquisa do Estado de são Paulo (FAPESP), ao Conselho Nacional de Desenvolvimento Científico e Tecnolōgico (CNPq) e à Financiadora de Estudos e Projetos (FINEP), pelo apoio material. 
1. INTRODUÇÃO

1.1. Ativação de oxigênio Molecular ............. 01

1.2. Regulação Biológica de Espécies Ativadas ..... 15

1.3. Aspectos Clínicos da Toxicidade por Oxigênio.. 24

1.4. A Poluição em Vila Parisi .............. 32

1.5. Porfiria Aguda Intermitente ............. 35

2. obJETIVOS .................................. 41

3. MATERIAIS E MÉTODOS

3.1. Abreviações ....................... 43

3.2. Enzimas e Reagentes ................... 44

3.3. Aparelhagem ....................... 44

3.4. Métodos ........................ 45

4. RESULTADOS

4.1. Grupo Controle .................... 58

4.2. Individuos Portadores de IAP ............. 58

4.3. Indivíduos Residentes em Vila Parisi ........ 65

5. DISCUSSÃO E CONCLUSÕES

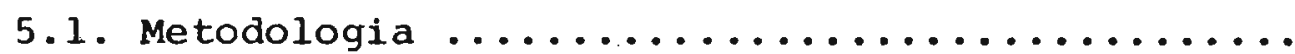

5.2. Níveis de SOD, Catalase e GSH-Px em Eritrócitos de Indivíduos Portadores de IAP .........

5.3. Atividades Eritrocitárias de SOD, Catalase e GSH-Px de Residentes em Vila Parisi ........

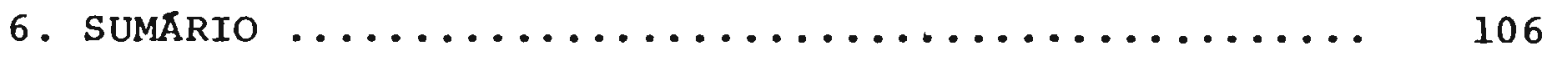

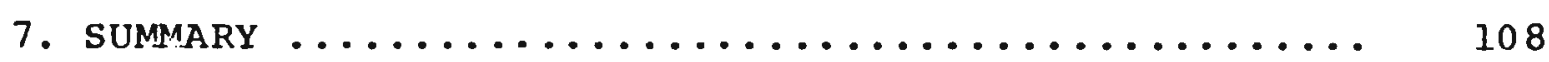




\subsection{Ativação de Oxigênio Molecular}

\subsubsection{Redução Biológica de oxigênio Molecular}

A vida dos organismos aeróbicos depende da manutenção de biomolēculas no estado reduzido, porém numa atmosfera oxidante, e da obtenção de energia via respiração, cuja etapa essencial consiste na redução de $\mathrm{O}_{2}$ a $\mathrm{H}_{2} \mathrm{O}$ :

$$
\mathrm{O}_{2}+4 \mathrm{H}^{+}+4 \mathrm{e}^{-} \underset{\text { oxidase }}{\stackrel{\text { citocromo }}{\text { oxidase }}} 2 \mathrm{H}_{2} \mathrm{O}
$$

o oxigênio molecular apresenta um estado fundamental triplete. Por outro lado, seus produtos de redução $\left(\mathrm{H}_{2} \mathrm{O}_{2}\right.$ e $\left.\mathrm{H}_{2} \mathrm{O}\right)$ apresentam um estado fundamental singlete. A redução direta de $\mathrm{O}_{2}$ por dois elétrons é, portanto, proibida pela conservação de spin. Existem alguns modos desta situação ser contornada, ou se ja, de o oxigênio molecular ser ativado (Nishinaga, 1977):

(i) excitação eletrônica a oxigênio singlete, ${ }^{1} 0_{2}$ (inver são de spin);

(ii) coordenação de $\mathrm{O}_{2}$ a complexos de metais de transição; e

(iii) redução de $\mathrm{O}_{2}$ em etapas de um elétron.

No último caso, os seguintes intermediários seriam produzidos: 
ESQUEMA I

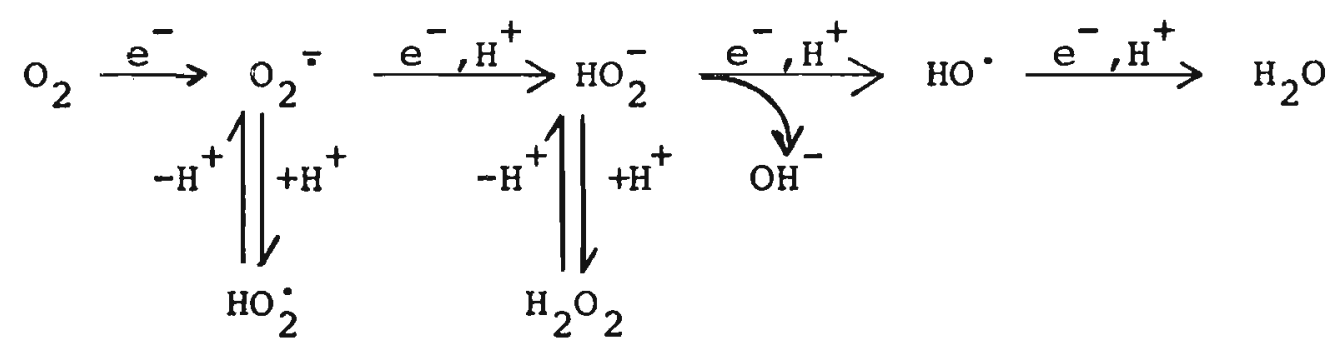

Apesar de $\mathrm{H}_{2} \mathrm{O}_{2}$ e $\mathrm{O}_{2}{ }^{-}$ocorrerem provavelmente em baixas concentrações, eles são metabolitos normais em cēlulas aeróbicas.

0 par $\mathrm{O}_{2}{ }^{-} / \mathrm{HO}_{2} \cdot$ (íon radical superóxido/radical perhidroxil) e $\mathrm{H}_{2} \mathrm{O}_{2}$ atuam frequentemente como oxidantes nucleofilicos (Michelson e colaboradores, 1977). As propriedades oxidantes e redutoras do par $\mathrm{O}_{2}{ }^{-} / \mathrm{HO}_{2}{ }^{-}$são fartamente demonstradas na literatura (Morooka e colaboradores, 1976). Alguns exemplos são citados abaixo:

(i) Miller e Rapp (1973)

$\bigcirc \int_{\mathrm{OH}}^{\mathrm{O}^{-}}+\mathrm{O}_{2}^{-}+\mathrm{H}^{+} \longrightarrow \mathrm{OH}_{\mathrm{OH}}^{\mathrm{O}^{\circ}}+\mathrm{HO}_{2}{ }^{\cdots}$

(ii) Bechara e Cilento (1971)<smiles>[R]N1C=CCC(C(N)=O)=CN1[R]O[PH3+]</smiles> 
(iii) Ballou e colaboradores (1969)

$$
\text { cit. } \mathrm{Fe}^{3+}+\mathrm{O}_{2}^{-} \longrightarrow \text { cit. } \mathrm{Fe}^{2+}+\mathrm{O}_{2}
$$

(iv) Sutton e colaboradores (1976)

met $\mathrm{Hb}\left(\mathrm{Fe}^{3+}\right)+\mathrm{O}_{2}^{-} \longrightarrow \mathrm{Hb}\left(\mathrm{Fe}^{2+}\right)+\mathrm{O}_{2}$

Em soluções aquosas, típicas de sistemas biológicos, as prô priedades químicas de $\mathrm{O}_{2}^{\overline{1}}$ são muito diferentes do que em solven tes orgânicos. Em pH fisiológico, a forma protonada $\mathrm{HO}_{2}$, que é agente oxidante mais forte que $\mathrm{O}_{2}^{\overline{1}}$. está presente em pequena concentração, pois seu $\mathrm{pK}_{\mathrm{a}}=4,8$. Assim, não faria sentido propor-se um papel biológico para o par $\mathrm{O}_{2}^{\bar{T}} / \mathrm{HO}_{2}^{*}$.

ESQUEMA II

$$
\begin{aligned}
& \mathrm{HO}_{2}^{\circ}+\mathrm{HO}_{2}^{-} \longrightarrow \mathrm{H}_{2} \mathrm{O}_{2}+\mathrm{O}_{2} \quad \mathrm{k}=8 \times 10^{5} \mathrm{M}^{-1} \mathrm{~s}^{-1} \\
& \mathrm{HO}_{2}^{-}+\mathrm{O}_{2}^{-} \longrightarrow \mathrm{HO}_{2}^{-}+\mathrm{O}_{2} \quad \mathrm{k}=9 \times 10^{7} \mathrm{M}^{-1} \mathrm{~s}^{-1} \\
& \mathrm{O}_{2}^{-}+\mathrm{O}_{2}^{-} \stackrel{\mathrm{H}^{+}}{\longrightarrow} \mathrm{HO}_{2}^{-}+\mathrm{O}_{2} \mathrm{k}<10^{2} \mathrm{M}^{-1} \mathrm{~s}^{-1}
\end{aligned}
$$

A hipótese do $\mathrm{O}_{2}^{\overline{1}}$ não ser reativo em sistemas biológicos po de ser contestada com a idéia de que, como grande parte do $0{ }_{2}^{\bar{*}}$ gerado nas células é originário de sistemas ligados a membrana, tais como cadeia de transporte de elétrons de cloroplasto, mito cöndria e retículo endoplasmātico e, sendo o interior de membranas hidrofóbico, as propriedades do íon superóxido nestes sistemas seriam semelhantes àquelas em solventes não aquosos (Halliwell, 
1978, referència citada em Halliwell, 1981). Tais efeitos têm sido atribuídos a espëcies reativas derivadas de $\mathrm{O}_{2}^{\bar{T}}$, principal mente radical hidroxil $\left(\mathrm{HO}^{\circ}\right)$ e oxigênio singlete $\left({ }^{1} 0_{2}\right)$. Existem algumas evidências de que esta última espécie é produzida atravês da reação de Haber-Weiss, catalisada por metais:

$$
\mathrm{O}_{2}^{-}+\mathrm{H}_{2} \mathrm{O}_{2} \stackrel{\mathrm{Me}^{2+}}{\longrightarrow}{ }^{1_{0}}+\mathrm{HO}^{\circ}+\mathrm{HO}^{-}
$$

Estes resultados ainda não foram satisfatoriamente interpretados, uma vez que compostos sequestradores de oxigênio singlete não são tão específicos como proposto originalmente. Sabe-se hoje que o próprio $\mathrm{o}_{2}^{-}$sequestra ${ }^{1} 0_{2}$ (Guiraud e Foote, 1976; Foote e colaboradores, 1980). Então antes que a ação de oxigênio singlete seja usada como explicação para os danos provocados por $\mathrm{O}_{2}^{\bar{*}}$, deve ficar estabelecido que ${ }^{1} \mathrm{O}_{2}$ é realmente produzido pelo sistema do ín $\mathrm{O}_{2}^{-}$.

Muitos dos efeitos deletérios do sistema $\mathrm{O}_{2}^{\bar{j}} / \mathrm{HO}_{2}$ são diminuídos por substāncias que sequestram HO', tais como manitol, formiato e tiouréia (Halliwell, 1981). As enzimas catalase e sụ peróxido dismutase (SOD) também atuam minimizando esses danos, sugerindo o possível envolvimento de espēcies $\mathrm{H}_{2} \mathrm{O}_{2}$, $\mathrm{HO}^{\circ}$ e $\mathrm{O}_{2}^{\bar{*}}$ ' das quais o radical $\mathrm{HO}^{\circ}$ é o mais deletério por causa da sua alta e indiscriminada reatividade.

Foi sugerido por Fridovich (1975) que $\mathrm{O}_{2}^{\overline{2}}$ e $\mathrm{H}_{2} \mathrm{O}_{2}$ podiam reagir entre si (reação de Haber-Weiss) gerando HO :

$$
\mathrm{O}_{2}^{-}+\mathrm{H}_{2} \mathrm{O}_{2} \longrightarrow \mathrm{HO}^{-}+\mathrm{HO}^{-}+\mathrm{O}_{2}
$$


Entretanto, como a constante de velocidade desta reação é muito pequena, $\left(\mathrm{k}<10^{-4} \mathrm{M}^{-1} \mathrm{~s}^{-1}\right.$, Rigo e colaboradores, 1977) sua importância seria reduzida pelas baixas concentrações de $\mathrm{O}_{2}^{\circ}$ e $\mathrm{H}_{2} \mathrm{O}_{2}$ presentes in vivo (Halliwell, 1978). Todavia, a rea ção de Haber-Weiss é termodinamicamente possível e, vārios tipos de íons de metais de transição presentes in vivo (princi palmente de ferrol poderiam agir como catalisadores. Neste caso pode ser proposta a seguinte sequência de reações (Halliwell, 1981):

ESQUEMA III

$$
\begin{aligned}
& \mathrm{Fe}^{2+}-\text { complexo }+\mathrm{O}_{2}^{-} \longrightarrow \mathrm{Fe}^{2+}-\text { complexo }+\mathrm{O}_{2} \\
& \mathrm{Fe}^{2+}-\text { complexo }+\mathrm{H}_{2} \mathrm{O}_{2} \longrightarrow \mathrm{Fe}^{3+}-\text { complexo }+\mathrm{HO}^{\circ}+\mathrm{HO}^{-} \\
& \text {(reação tipo Fenton) }
\end{aligned}
$$

ou, $\mathrm{O}_{2}^{-}+\mathrm{H}_{2} \mathrm{O}_{2} \stackrel{\mathrm{Fe}^{3+}}{\longrightarrow} \mathrm{O}_{2}+\mathrm{HO}^{\circ}+\mathrm{HO}^{-}$

Este pode não ser o mecanismo correto, mas fornece uma possível explicação de como SOD e catalase poderiam inibir a formação do radical $\mathrm{HO}^{\circ}$. A capacidade do sistema de $\mathrm{O}_{2}^{-}$gerar $\mathrm{HO}^{\circ}$ na presença de íons de ferro tem sido demonstrada pela habilidade de tais radicais degradarem triptofano (McCord e Day, 1978), hidroxilarem compostos aromáticos (Halliwel1, 1978a) e reagirem com "spin-traps" (Buettner e colaboradores, 1978).

Existe ainda muita controvérsia a respeito da importância biológica da reação de Haber-Weiss catalisada por metais. Para aceitá-la como explicação da toxicidade de sistemas que geram ions $\mathrm{O}_{2}^{-}$, deve-se procurar evidências de que a proteçäo contra a 
formação de $\mathrm{HO}^{*}$ pode ser feita tanto pela remoção de $\mathrm{O}_{2}^{\bar{T}}$ como de $\mathrm{H}_{2} \mathrm{O}_{2}$. Assim, por exemplo, é bastante significativa a ocorrência de organismos que não têm catalase e peroxidase, mas, apenas atividade de SOD (Fridovich, 1975; Halliwell, 1978b). Existe tam bém o caso do gnococcus, que é uma bactéria aeróbica que pode sobreviver e replicar-se no interior de fagocitos sob um grande fluxo de $\mathrm{O}_{2}^{\overline{-}}$ e $\mathrm{H}_{2} \mathrm{O}_{2}$ e não contém SOD, mas uma atividade extremamente alta de catalase (Norrod e Morse, 1979). Deve-se ressaltar aqui o caso do procarioto mycoplasma pneumoniae que, apesar de consumir oxigênio e gerar $\mathrm{O}_{2}^{-}$, não tem atividade detectāvel de SOD ou catalase, faltando, no entanto, determinar se existem outros caminhos de inativação de espécies ativadas de oxigênio como sua redução por glutationa ou decomposição de $\mathrm{H}_{2} \mathrm{O}_{2}$ catalisada por NADH peroxidase (Lynch e Cole, 1980). No entanto, a maioria dos organismos aeróbicos tem os dois sistemas de proteção: SOD e enzimas responsāveis pela remoção de $\mathrm{H}_{2} \mathrm{O}_{2}$.

1.1.2. Fontes Biológicas de Espécies Ativadas de Oxigênio Molecular

Em fígado de rato, espécies ativadas de oxigênio podem ser produzidas em duas categorias de reações (Oshino e Chance, 1977): (i) redução divalente de $\mathrm{O}_{2}$ por oxidase e (ii) redução univalente de $\mathrm{O}_{2}$ a $\mathrm{O}_{2}^{\bar{j}}$ em certas reações enzimáticas (Sies, 1974). Discutiremos brevemente a contribuição de cada fração subcelular isolada na produção de espécies ativadas de oxigênio. 


\subsubsection{Mitocôndrias}

As membranas mitocondriais foram reconhecidas como possíveis fontes fisiológicas de $\mathrm{H}_{2} \mathrm{O}_{2}$ quando se demonstrou que partículas submitocondriais obtidas por sonicação ou por tratamento al calino produzem $\mathrm{H}_{2} \mathrm{O}_{2}$ (Hinkle e colaboradores, 1967; Jensen, 1966).

Partículas submitocondriais de coração de rato são fontes efetivas de $\mathrm{H}_{2} \mathrm{O}_{2}$ (Boveris e Cadenas, 1975) e uma vez que são destituidas de dehidrogenases auxiliares, tais como flavoproteí nas para oxidação de ácidos graxos, a formação de $\mathrm{H}_{2} \mathrm{O}_{2}$ pode ser diretamente relacionada com os componentes da cadeia respiratória. Como uma das etapas de oxiredução da cadeia respiratória se processa no segmento succinato dehidrogenase-citocromo $b$, foi investigado a formação de $\mathrm{O}_{2}^{\overline{0}}$ como produto de redução primária de oxigênio neste sítio. Neste caso, as partículas submitocondriais geraram de 4 a $7 \mathrm{nmol} \mathrm{O}_{2}^{-} / \mathrm{min}$ por miligrama de proteína numa relação $\mathrm{O}_{2}^{\bar{j}} / \mathrm{H}_{2} \mathrm{O}_{2}=1,5$ a 2,1 (Boveris e Cadenas, 1975; Boveris e colaboradores, 1973; Dionisi e colaboradores, 1975), mos trando que $\mathrm{O}_{2}^{\bar{j}} \bar{e}$, na verdade, quase um precursor estequiométrico de $\mathrm{H}_{2} \mathrm{O}_{2}$ mitocondrial. Considerando os níveis de $\mathrm{H}_{2} \mathrm{O}_{2}$, as mem branas mitocondriais podem produzir cerca de $24 \mathrm{nmol} \mathrm{O}_{2}^{\bar{T}} / \mathrm{min}$. por grama de tecido no fígado (Boveris e colaboradores, 1972) e são aparentemente uma das principais fontes fisiológicas de $0_{2}^{-}$.

\subsubsection{Peroxisomas}

Esta organela de fígado e de outros órgãos contēm um gran- 
de nümero de enzimas que geram $\mathrm{H}_{2} \mathrm{O}_{2}$, incluindo algumas flavopro teínas tais como a D-aminoācido oxidase, a L- -hidroxiācido oxi dase e a urato oxidase. No caso da reação catalisada pela lactá to oxidase, a produção de $\mathrm{H}_{2} \mathrm{O}_{2}$ está ilustrada pelo esquema abai xo (Flashner e Massey, 1974):

ESQUEMA IV

$\mathrm{EFMN}+\mathrm{R}-\mathrm{CHOH}-\mathrm{COOH} \leftrightharpoons \mathrm{EFMN}-\mathrm{R}-\mathrm{CHOH}-\mathrm{COOH} \leftrightharpoons \mathrm{EFMNH}_{2}-\mathrm{R}-\mathrm{CO}-\mathrm{COOH}$
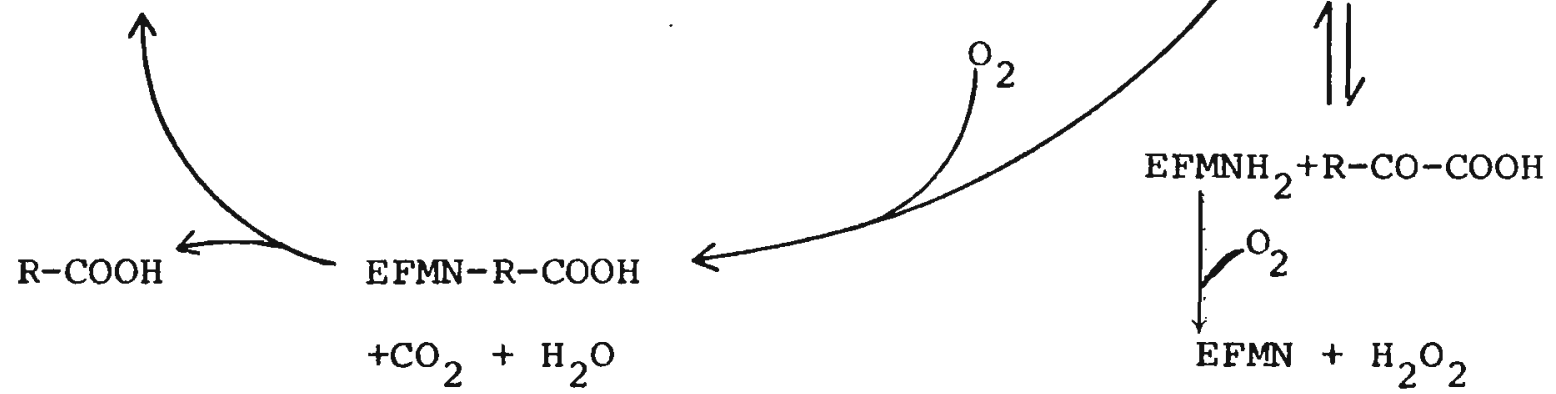

Lazarow e De Duve (1976) observaram a formação de $\mathrm{H}_{2} \mathrm{O}_{2}$ dependente de uma palmitoil-CoA desidrogenase em frações peroxiso mais isoladas de fígado de rato o que coloca, também, os ācidos graxos na lista de substratos potenciais de produção de $\mathrm{H}_{2} \mathrm{O}_{2}$ nos peroxisomas.

\subsubsection{Retículo Endoplasmātico}

A autoxidação do citocromo $\mathrm{P}_{450}$ fornece $\mathrm{O}_{2}^{\bar{T}}$, e diversos tra balhos (Bartoli e colaboradores, 1977; Estabrook e werringloer, 1977; Mishin e colaboradores, 1976) indicam uma produção de quan- 
tidades consideräveis de $\mathrm{O}_{2}^{\bar{T}}$ por microsomas isolados. O sistema flavoproteína-NADPH-citocromo c redutase e citocromo $P_{450}$ são as fontes mais prováveis de $\mathrm{H}_{2} \mathrm{O}_{2}$ e $\mathrm{O}_{2}^{\bar{a}}$ nessas membranas (Hildebrant e Roots, 1975)

\subsubsection{Enzimas do Citosol}

Enzimas como xantina-oxidase e aldeído oxidase contribuem para a produção de $\mathrm{H}_{2} \mathrm{O}_{2}$. Entretanto, a quantificação desta contribuição no sobrenadante, após fracionamento celular, indicou um valor de apenas cerca de $5 \%$ da produção celular de $\mathrm{H}_{2} \mathrm{O}_{2}$ (Boveris e colaboradores, 1972). Contudo, é muito difícil avaliar esta produção em condições fisiológicas.

1.1.2.5. Produção química e in vitro de espēcies ativadas.

A produção química e bioquímica de $\mathrm{O}_{2}^{-}$e $\mathrm{HO}^{\cdot}$ é também dis cutida detalhadamente em trabalhos de Michelson e colaboradores e de Fridovich (1977). São mencionados vārios mētodos, entre eles:

(i) irradiação de meio aquoso aerado com raios $x$, raios $\gamma$, raios cósmicos e elétrons acelerados:

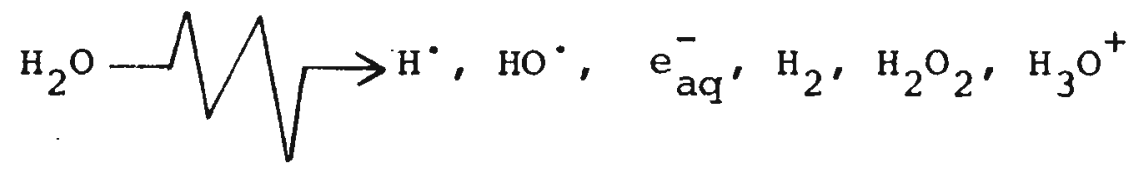


Na presença de $\mathrm{O}_{2}$ :

$$
\begin{aligned}
& \mathrm{H}^{\circ}+\mathrm{O}_{2} \longrightarrow \mathrm{HO}_{2}^{\circ} \rightleftharpoons \mathrm{H}^{+}+\mathrm{O}_{2}^{-} \\
& \mathrm{e}_{\mathrm{aq}}^{-}+\mathrm{O}_{2} \longrightarrow \mathrm{O}_{2}^{-}
\end{aligned}
$$

$\mathrm{HO}_{2}^{*}$ e $\mathrm{O}_{2}^{\overline{0}}$ reagem com cutras moléculas e também outras es pécies reativas formando, por exemplo:

$$
\mathrm{O}_{2}^{-}+\mathrm{H}_{2} \mathrm{O}_{2} \longrightarrow \mathrm{HO}^{-}+\mathrm{OH}^{*}+\mathrm{O}_{2} \text { (Reação de Haber-Weiss) }
$$

Niwa e colaboradores (1977) discutiram a proteção promovida por SOD em radioterapia denominada "efeito $\mathrm{O}_{2}$ " Oxigênio molecular aumenta a radiosensibilidade de organismos vivos (micrō bios, plantas e animais), ocasionando alterações no crescimento, mutação e morte. Os seres humanos são radioresistentes devido a altos níveis de SOD (Hartz e colaboradores, 1973).

(ii) oxidação de oxihemoglobina, sob certas condições, a met hemoglobina (Misra e Fridovich, 1972):

$\mathrm{oxi} \mathrm{Hb}\left(\mathrm{Fe}^{2+} \mathrm{O}_{2}\right) \longrightarrow \operatorname{met} \mathrm{Hb}\left(\mathrm{Fe}^{3+}\right)+\mathrm{O}_{2}^{-}$

(iii) produção de $\mathrm{O}_{2}^{\overline{2}}$ na oxidação de $\mathrm{NADPH}$ por $\mathrm{O}_{2}$ ' catalisada por uma enzima ligada a membrana de neutrófilos poli morfonucleares, denominada superóxido sintetase (Goldstein e co laboradores, 1975). Esta enzima atua durante a fogositose de bactērias e outros materiais estranhos. 
Uma vez que espécies ativadas de oxigênio são interconvertíveis através de reações do tipo:

ESQUEMA V

$$
\begin{aligned}
2 \mathrm{O}_{2}^{-} & \stackrel{2 \mathrm{H}^{+}}{\longrightarrow} \mathrm{O}_{2}+\mathrm{H}_{2} \mathrm{O}_{2} \\
\mathrm{O}_{2}^{-}+\mathrm{H}_{2} \mathrm{O}_{2} & \longrightarrow \mathrm{HO}^{-}+\mathrm{HO}^{-}+\mathrm{O}_{2} \\
\mathrm{HO}^{-}+\mathrm{H}_{2} \mathrm{O}_{2} & \longrightarrow \mathrm{H}_{2} \mathrm{O}+\mathrm{HO}_{2}^{-}
\end{aligned}
$$

todas as células aeróbicas, procarióticas e eucariōticas, con-têm um certo nível dessas espécies, limitado pela velocidade de produção comparada com a velocidade de destruição por despropor cionamento espontâneo catalisado por enzimas e por outros processos.

1.1.3. Toxicidade de espécies ativadas de oxigênio

Apesar do oxigênio ser essencial para a sobrevivência de organismos aeróbicos ele é tóxico quando presente em concentrações superiores a do ar atmosférico.Animais expostos a pressões de oxigênio de cerca de 2 ou 3 atm apresentam sintomas que se in ciam com convulsões generalizadas (Van Den Brenk e Jamieson, 1964) seguidos de sérios danos pulmonares (Wood e Perkins,1970)。 A maioria dos tecidos humanos (se não, todos) é sensível a danos por oxigênio. 
Como comentamos anteriormente, a ação töxica de $\mathrm{H}_{2} \mathrm{O}_{2}$ e $\mathrm{O}_{2}^{\overline{5}}$ ë devida, aparentemente, a capacidade de tais espécies de oxidar substâncias como adrenalina, ou reduzir citocromo $\mathrm{c}$ e outras hemeproteínas e tambēm de iniciar reações radicalares em cadeia lovando à peroxidação de lipídeos (Chance e colaboradores, 1979).

Como consequências da peroxidação de lipídeos, temos (i) a perturbação da microestrutura de membranas devido a introdução de funções hidrofĩlicas, (ii) inibição de atividades enzimāticas dependentes de grupos $\mathrm{SH}$ por hidroperóxidos: e (iii) reações subsequentes dos produtos de quebra, tais como os aldeídos, e (iv) "fotobioquímica no escuro" (Cilento, 1980).

Foi observado também, que a toxicidade radioativa envolve essencialmente os mesmos intermediários de $\mathrm{O}_{2}$ que são responsáveis por toxicidade por oxigênio. Observa-se uma proteção signi ficante de superóxido dismutase em bactērias submetidas à radia ção ultiavioleta (365 nm).

o İon superóxido é, portanto, responsável por danos efetivos em diversas estruturas biológicas tais como ácidos nucleicos, proteínas e lipídeos e, consequentemente, provoca alterações letais quando sua concentração è tão grande que não possa ser controlada pelas enzimas intracelulares.

Tem sido proposto também, por diversos autores, o envolvimento de espécies ativadas de oxigênio em processos de envelhecimento (Harman, 1971). Isto foi baseado no fato de que crescimento celular sob baixa tensão de oxigênio (Packer e Fuehr, 1970) ou na presença de vitamina E (Packer e Smith, 1974) aumentam o tempo de vida em que células humanas diplóides podem se replicar. 
Uma vez que espécies ativadas de oxigênio podem ser tóxicas para diferentes componentes e estruturas celulares como moléculas pequenas, macromolēculas, material genético e membranas em geral, deve ser ressaltado aqui a ameaça que estas espécies representariam para a célula, caso sua produção in vivo não fosse controlada.

1.1.4. Outros meios de Ativação de Oxigênio Molecular

Relembramos aqui que a redução de $\mathrm{O}_{2}$ em etapas de um elétron dando $\mathrm{O}_{2}^{-}, \mathrm{HO}^{\circ}$ e $\mathrm{H}_{2} \mathrm{O}_{2}$ não é o ünico meio de ativação de oxigênio molecular. Isto também pode se processar, por exemplo, através da excitação eletrônica a oxigênio singlete, que è devida a uma perturbação nos orbitais $\pi^{*}$, sem envolver um processo de transferência de elétrons.

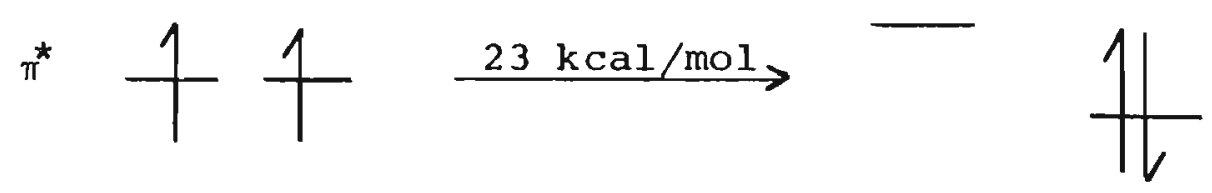

O oxigênio singlete é produzido em vários processos envolvendo reações de fotosensitização, irradiação com microondas e em reações químicas que utilizam $\mathrm{H}_{2} \mathrm{O}_{2}$ e ozone (Kearns, 1971).

A seguir, exemplificamos algumas reações típicas de ${ }^{1} 0_{2}$ (Foote, 1976):

i) Adição-1,4 em dienos e heterociclos, formando um endope róxido: 


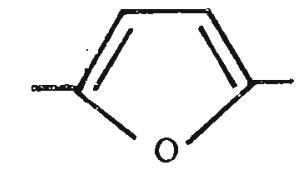

2,4-dimetil furano

$$
\frac{\mathrm{h} v / \text { sens. }}{\mathrm{O}_{2},-80^{\circ}}
$$

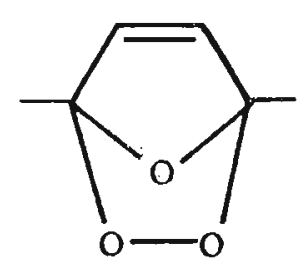

endoperóxido

ii) Adição-1,3 a olefinas, com produção de hidroperóxido alílico:

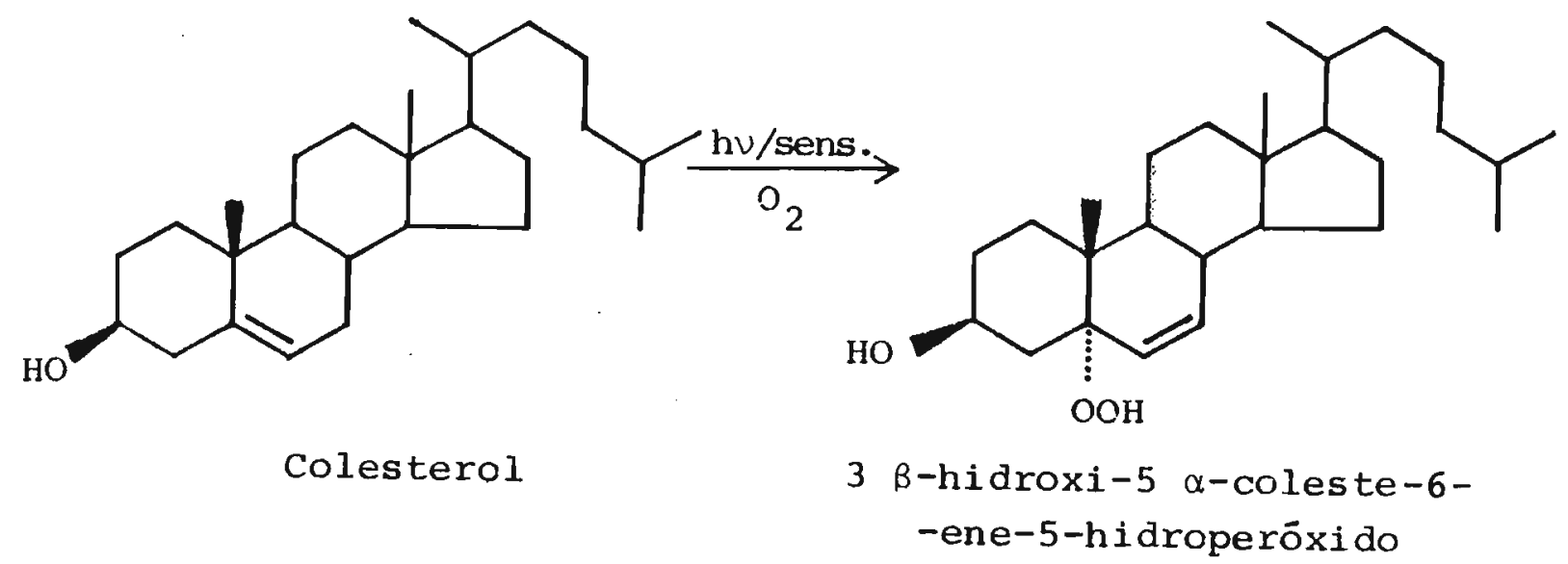

iii) Adição-1,2 a certas olefinas de alta densidade eletrôni ca, como enaminas e éteres vinílicos:

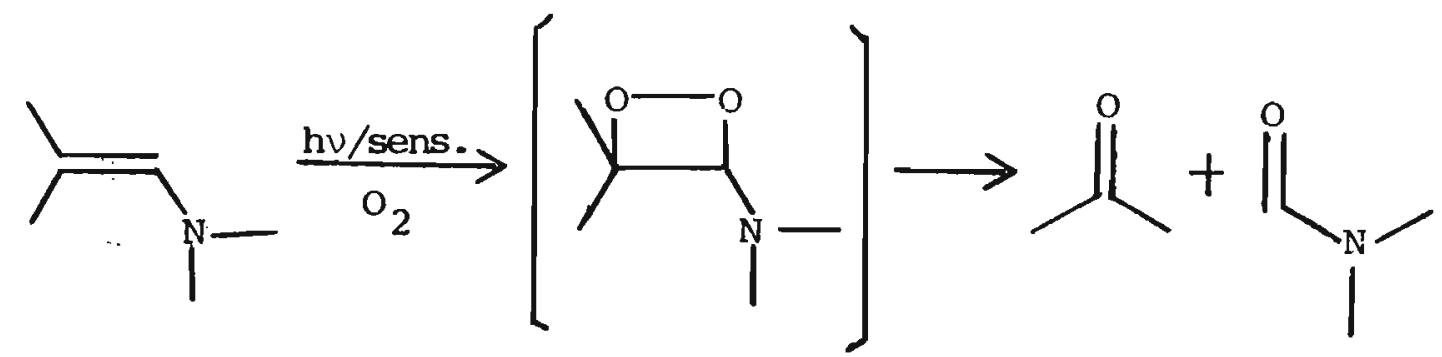

iv) Oxidação de sulfetos à sulfóxidos:

$\left(\mathrm{C}_{2} \mathrm{H}_{5}\right)_{2} \mathrm{~s} \stackrel{\mathrm{h} \nu / \text { sens }}{\mathrm{O}_{2}}\left[\left(\mathrm{C}_{2} \mathrm{H}_{5}\right)_{2} \stackrel{\mathrm{s}-\mathrm{O}-}{\longrightarrow} \mathrm{O}\right] \underset{\left(\mathrm{C}_{2} \mathrm{H}_{5}\right)_{2} \mathrm{~S}}{\longrightarrow} 2\left(\mathrm{C}_{2} \mathrm{H}_{5}\right)_{2} \stackrel{+}{\mathrm{S}}-\mathrm{O}^{-}$ 
v) Fotooxidação de fenóis:

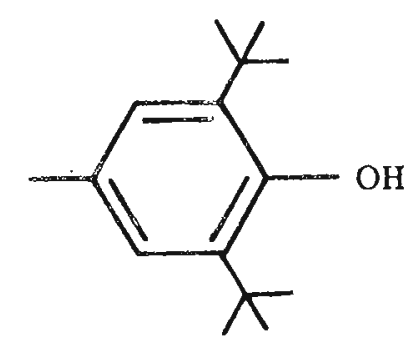

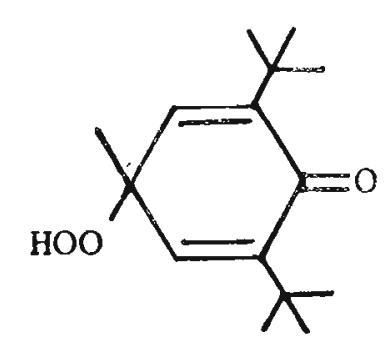

O oxigênio molecular também pode ser ativado através da co ordenação com complexos de metais de transição (Nishinaga, 1977). A estrutura e estado eletrônico que resultam desta complexação depende da natureza do metal ligante. A reatividade do $\mathrm{O}_{2}$ coordenado está diretamente relacionado com a natureza desta coorde nação.

\subsection{Regulação Biológica de Espécies Ativadas}

1.2.1. Catalase, Superóxido Dismutase (SOD) e Glutationa Peroxidase (GSH-PX).

Embora presentes em baixas concentrações, os produtos de redução do oxigênio são metabólitos normais em células aeróbicas. A defesa contra essas espécies tóxicas è devida, principal mente, à baixa tensão de oxigênio nos tecidos, a qual é mantida, em primeiro plano, pelo sistema microvascular. As arteríolas são sensiveis a altas pressões de oxigênio, o que leva à diminuição da circulação de sangue no órgão em questão.

A proteção biológica contra efeitos tóxicos associados com níveis excessivos de $\mathrm{O}_{2}^{\overline{1}}, \mathrm{H}_{2} \mathrm{O}_{2}$ e $\mathrm{OH}^{\bullet}$ tem sido atribuída a três 
enzimas principais, presentes em eritrócitos e outras células: superóxido dismutase, catalase e glutationa peroxidase.

A catalasse è amplamente distribuída em animais plantas e bactërias (Nicholls e Schombaum, 1963). Está localizada, predominantemente, em organelas subcelulares tais como peroxisomas de fígado e rim e em agregados menores tais como microperoxisomas em uma variedade de outras células. Todas as catalases isoladas até agora têm 4 átomos de ferro por molécula. O ferro está presente na forma de 4 grupos prostēticos $\mathrm{Fe}^{3+}$-protoporfirina IX, exceto nas catalases de fígado onde um ou mais grupos prostēticos estão degradados como pigmentos de bile.

A catalase exibe āois tipos de atividade (catalásica e peroxidásical com características cinéticas completamente diferen tes (Schombaum e Chance, 1976). As três equações abaixo descrevem a cinética da catalase na sua função catalásica (Eq. I e 2) e peroxidásica (Eq̣. 1 e 3):

ESQUEMA VI

(1) catalase $-\mathrm{Fe}^{3+}+\mathrm{H}_{2} \mathrm{O}_{2} \stackrel{\mathrm{k}}{\mathrm{I}} \rightarrow$ composto $\mathrm{I}$

(2) composto $\mathrm{I}+\mathrm{H}_{2} \mathrm{O}_{2} \stackrel{\mathrm{k}_{4}^{\prime}}{\longrightarrow}$ catalase $-\mathrm{Fe}^{3+}+2 \mathrm{H}_{2} \mathrm{O}+\mathrm{O}_{2}$

(3) composto $\mathrm{I}+\mathrm{AH}_{2} \stackrel{\mathrm{k}_{4}}{\longrightarrow}$ catalase $-\mathrm{Fe}^{3+}+2 \mathrm{H}_{2} \mathrm{O}+\mathrm{A}$

$$
\begin{aligned}
& \mathrm{k}_{1}=1,7 \times 10^{7} \mathrm{M}^{-1} \cdot \mathrm{s}^{-1} \\
& \mathrm{k}_{4}^{\prime}=2,6 \times 10^{7} \mathrm{M}^{-1} \cdot \mathrm{s}^{-1} \\
& \mathrm{k}_{4}=0,2-1 \times 10^{3} \mathrm{M}^{-1} \cdot \mathrm{s}^{-1}
\end{aligned}
$$


A catalase è bastante específica para peróxidos, uma vez que apresenta atividade apreciável somente para hidrogênio-, me til- e etilhidroperóxidos. No caso dos doadores de hidrogênio $\left(\mathrm{AH}_{2}\right)$, incluem-se uma sequência similar de álcoois alifáticos, com alta atividade para metil- e etil derivados e baixa ativida de para butil- e homólogos maiores.

A glutationa peroxidase $(\mathrm{GSH}-\mathrm{Px})$, catalisa a reação de hidroperóxidos com glutationa reduzida (GSH) para formar glutatio na oxidada (GSSG) e o produto de redução de hidroperóxido, segundo a reação abaixo:

$\mathrm{ROOH}+2 \mathrm{GSH} \longrightarrow \mathrm{ROH}+\mathrm{GSSG}+\mathrm{H}_{2} \mathrm{O}$

Esta enzima apresenta alta atividade no fígado e em eritró citos e uma baixa atividade nos músculos (Chow e Tappel, 1972). A glutationa peroxidase é específica para o doador de hidrogênio (GSH) mas não tem especificidade para o hidroperóxido. Com isso, a variação de possíveis substratos se estende desde $\mathrm{H}_{2} \mathrm{O}_{2}$ até hidroperóxidos orgânicos entre os quais hidroperóxidos lipí dicos de vārias estruturas.

A glutationa peroxidase contém um átomo de selênio por sub unidade (4 subunidades), e, ao contrário de diversas peroxidases de origem animal (lactoperoxidase, mieloperoxidase, percxidase de tiróide), não tem grupo prostético derivado de hemina.

Sua distribuição celular em fígado de rato é complementar a da catalase: dois terços da enzima no citosol e um terço na mitocondria e não existe glutationa peroxidase nos peroxisomas. 
portanto, o fato da glutationa peroxidase compartilhar o metabo lismo da $\mathrm{H}_{2} \mathrm{O}_{2}$ com a catalase está baseado na forma de compartimentalização das duas enzimas nas células.

A glutationa peroxidase constitui a primeira linha de defe sia contra oxidações danosas ao organismo causadas por $\mathrm{H}_{2} \mathrm{O}_{2}$ ou peröxidos lipídicos produzidos em várias células do corpo (Cohen e Hochstein, 1963). A identificação dos produtos através da redução de peróxidos lipídicos pela glutationa peroxidase sugere que esta enzima bloqueia a reação autocatalítica em cadeia da peroxidação de lipídeos impedindo danos à membrana causados por processos oxidativos (Christophersen, 1969). Altos níveis de hi droperóxidos derivados de aldeídos, ácidos, ēsteres e tioesteres poderiam levar à formação de produtos de clivagem C - CO, dando um produto eletronicamente excitado que levariam a proces sos com a potencialidade de "fotoquímica no escuro" (Cilento, 1980).

A superóxido dismutase, descrita por McCord e Fridovich em 1968, catalisa o desproporcionamento de $\mathrm{O}_{2}^{-}$:

$$
2 \mathrm{O}_{2}^{-}+2 \mathrm{H}^{+} \stackrel{\mathrm{SOD}}{\longrightarrow} \mathrm{O}_{2}+\mathrm{H}_{2} \mathrm{O}_{2}
$$

Sabe-se hoje que os superóxidos dismutases são metaloproteínas presentes em todas as células aeróbicas (Fridovich, 1972, 1974, 1975). São conhecidas três classes desta enzima,todas com a mesmä atividade catalítica, mas diferindo na natureza do metal presente no sítio ativo. A eritrocupreina contém $2 \mathrm{Cu}^{2+}$ e $2 \mathrm{Zn}^{2+}$ em duas subunidades idênticas e está presente no cito- 
plasma de células eucarióticas e tambẻm em cloróplastos.

O mecanismo de ação enzimätica da eritrocupreina foi proposto por Fridovich (1979) como:

ESQUEMA VII

$$
\begin{aligned}
& \mathrm{Cu}^{2+}+\mathrm{O}_{2}^{-} \longrightarrow\left[\mathrm{Cu}-\mathrm{O}_{2}\right]^{+} \\
& {\left[\mathrm{Cu}-\mathrm{O}_{2}\right]^{+}+\mathrm{O}_{2}^{-}+2 \mathrm{H}^{+} \longrightarrow \mathrm{Cu}^{2+}+\mathrm{H}_{2} \mathrm{O}_{2}+\mathrm{O}_{2}}
\end{aligned}
$$

Na mitocôndria encontra-se maior atividade de uma superóxí do dismutase contendo $\mathrm{Mn}^{2+}\left(2 \mathrm{Mn}^{2+}\right.$ e 4 subunidades). Algumas bac tērias e algas contêm um tipo de superóxido dismutase contendo ferro como componente metálico. Uma diferença importante entre estas enzimas é que cianeto inibe a eritrocupreina e não tem ne nhum efeito nas superóxidos dismutases contendo ferro e man ganês.

Michelson (1977) discutiu recentemente os efeitos de siste mas produtores de $\mathrm{O}_{2}^{\overline{2}}$ e de espēcies ativas associadas sobre vārias macromoléculas, bactérias e células eucariōticas e a protẹ ção promovida pela superóxido dismutase, catalase e glutationa peroxidase. Níveis muito altos de $\mathrm{O}_{2}^{\top}$ devido a baixa concentração de superóxido dismutase poderiam resultar na oxidação de vạ rios neuromediadores (vide ítem 1.2.15) em danos a membranas e estruturas subcelulares (mitocōndria de fígado, por exemplo, causando problemas hepáticos), em lesões a material genético, etc. Se por outro lado, a superóxido dismutase está presente em con- 
centrações acima do normal, várias reações enzimāticas, onde $\mathrm{O}_{2}^{\overline{1}}$ è intermediārio, seriam bloqueadas, como biossíntese de neurotransmissores e a destruição oxidativa de halucinógenos (por ex. a triptamina) podendo levar a debilidade mental e outras aberrações. Assim, por exemplo, a biossintese de norepinefrina a partir de tirosina, onde o passo final envolve a hidroxilação de dopamina por uma oxigenase, acoplada com a oxidação de ascorbato (Vannes te e Zuberkühler, 1974), é mediado por íons superóxido:<smiles>NCCc1ccc(O)c(O)c1</smiles>

dopamina

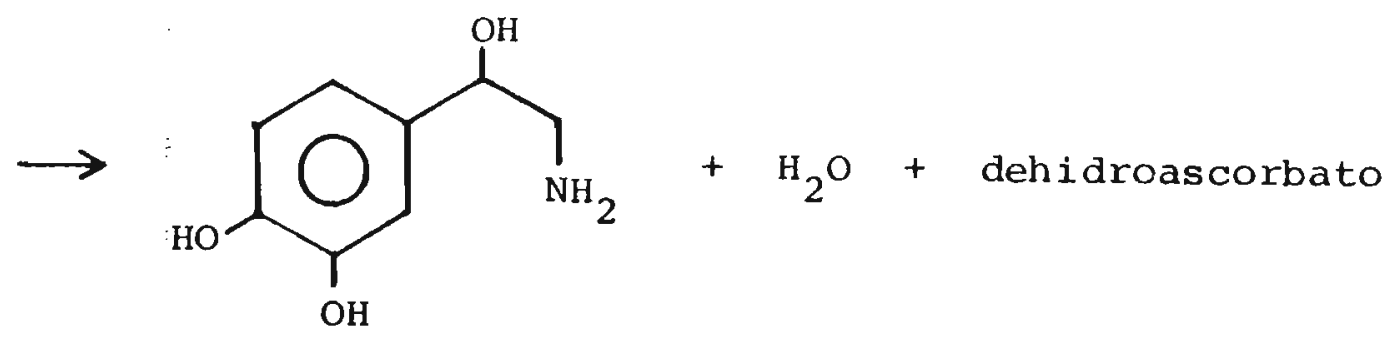

norepinefrina

Níveis anormais de $\mathrm{H}_{2} \mathrm{O}_{2}$ e peróxidos orgânicos podem, como já foi visto, exercer ação tóxica iniciando peroxidação de lipí deos, inibindo reações enzimāticas, etc. A principal defesa ce lular contra níveis anormais destas espécies é exercida pela glutationa peroxidase e catalase.

1.2.2. Outros Tipos de Regulação

Alëm do controle exercido pela superōxido dismutase, catalase e glutationa peroxidase, são conhecidas oútras enzimas que 
metabolizam produtos de redução do oxigênio como mostraremos a seguir.

\subsubsection{Heme peroxidases}

As heme peroxidases estão entre as enzimas mais estudadas por causa da sua ampla distribuição e estabilidade química. Yamazaki (1974) e Dunford e Stillman (1976) elaboraram uma revisão detalhada sobre a função e estrutura de peroxidases. Comentaremos brevemente algumas peroxidases de mamíferos.

A lactoperoxidase, presente nas glândulas salivares e mamá rias utiliza doadores de hidrogênio comuns como pirogalol,guaia col e benzidina (Sauders e colaboradores, 1964, referência citada em Chance e colaboradores, 1979). Tem-se sugerido que esta peroxidase age como inibidor do crescimento de bactérias crais uma vez que lactoperoxidase, peróxidos e haletos podem inibir o crescimento aerōbico de alguns microorganismos (Morrison e cola boradores, 1965).

A peroxidase de tiróide, catalisa a oxidação de iodeto a iodo, desempenhando um papel importante na sintese de hormônios tiroidianos. Jä a mieloperoxidase, encontrada em neutrófilos, de sempenha função fisiológica em células fagocitósicas.

\subsubsection{Citocromo Oxidase}

o citocromo $a_{3}$ é a oxidase terminal da principal via de res 
piração celular. Diversas evidências da formaçãó de intermediários de redução neste sítio, sugerem que a redução de oxigênio até $\mathrm{H}_{2} \mathrm{O}$ se processa em passos de um eletron (Chance e colaboradores, 1979). Entretanto, para prevenir que os ṕrodutos de redu ̧̧̃o do oxigênio causem danos ao meio externo caso sejam liberados, o peróxido fica firmemente ligado ao heme da cxidase até a redução final a $\mathrm{H}_{2} \mathrm{O}$.

\subsubsection{Citocromo $\mathrm{P}_{450}$}

A cadeia de transporte de elétrons do NADPH para citocromo $\mathrm{P}_{450}$ ' localizada na membrana do retículo endoplasmático, em mitocondria da córtex adrenal e em outros örgãos, catalisa reações de monooxigenação de substratos endógenos ou substâncias provindas do meio externo como drogas (Orrenius e Ernster, 1974). o mecanismo de ação desta enzima, proposto por Estabrook e colą boradores (1971), está esquematizado na figura abaixo:

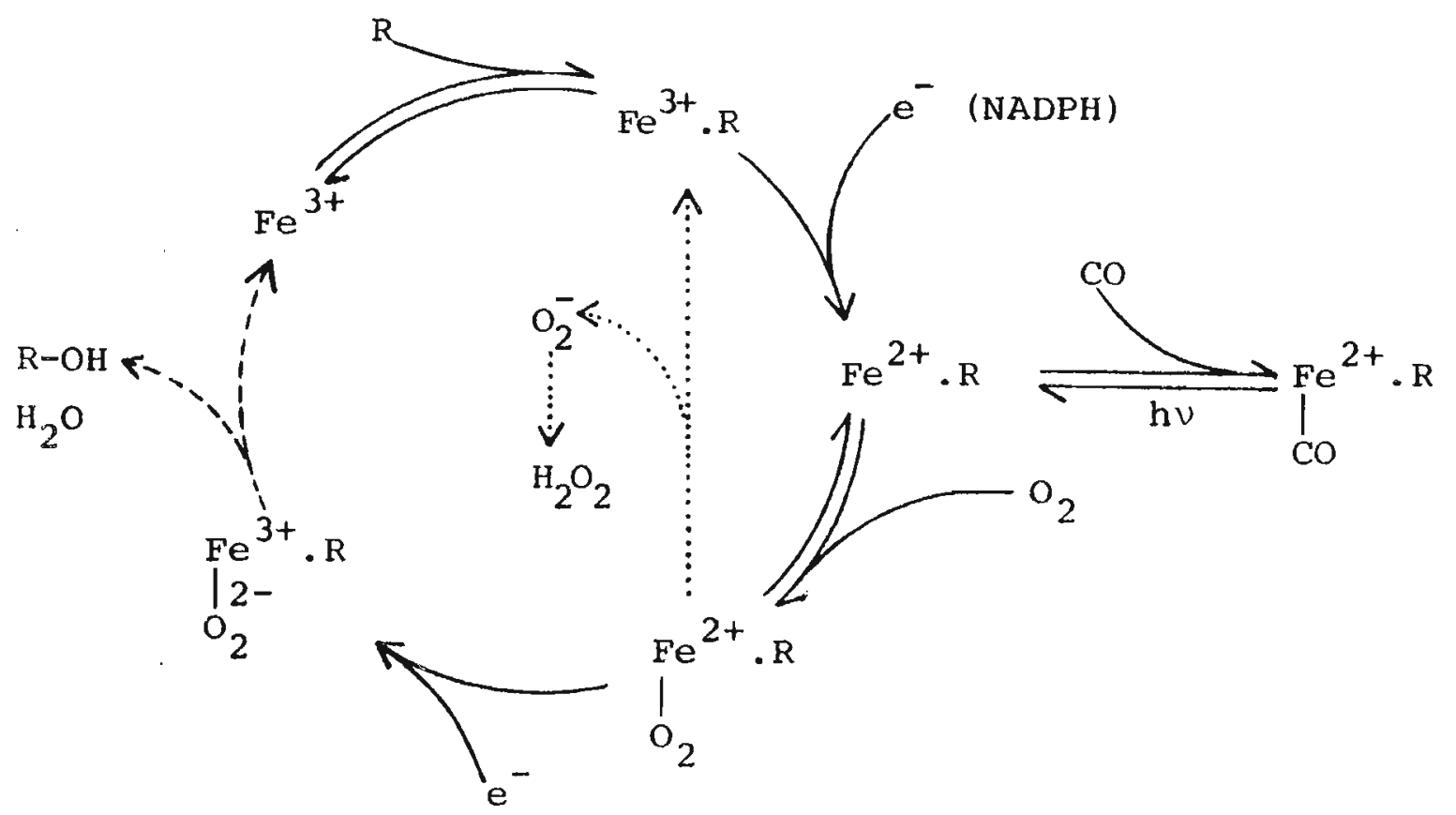

(NADH OU NADPH) 
A indolamina 2,3-dioxigenase è uma dioxigenase, contendo grupo heme, que catalisa a clivagem oxidativa de indolaminas substituidas ou não, tais como triptofano, 5-hidroxitriptofano, triptamina e serotonina (Hirata e Hayaishi, 1972). Recentemente foi demonstrado que esta enzima utiliza $\mathrm{O}_{2}^{\overline{ }}$ ao invés de oxigênio molecular como agente oxidante (Hirata e Hayaishi, 1977).

1.2.1.5. Remoção de íons superōxidos por catecolami nas

Um dos primeiros métodos de dosagem de SOD foi baseado na capacidade de epinefrina, uma catecolamina, em remover ions superóxido (McCord e Fridovich, 1969). Nesta reação, a epinefrina é transformada em um produto avermelhado, o adrenocromo.<smiles>CNCC(O)c1ccc(O)c(O)c1</smiles>

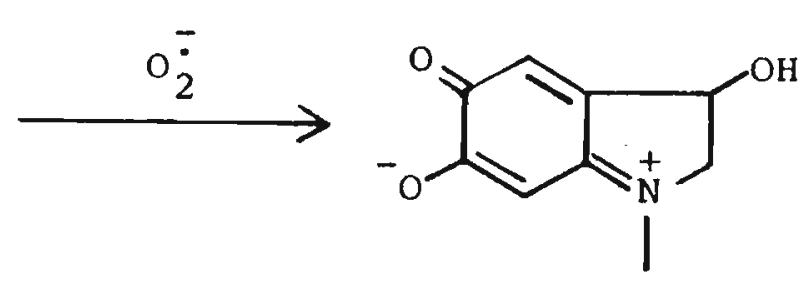

adrenocromo

A SOD intercepta os íons $\mathrm{O}_{2}^{-}$, gerados pelo sistema xantinaoxidase, e inibe o aparecimento da cor vermelha. Mais tarde, foi descrito por Misra e Fridovich (1972), um sistema de dosagem desta enzima baseado na autoxidação da epinefrina. Os íons superöxidos 
eram gerados durante a reação entre epinefrina e oxigênio molecular. Foi então proposto que $0_{2}^{-}$catalisa a reação propagando espécies radicalares em um mecanismo de reação em cadeia. Estes estudos estabeleceram a ação da epinefrina como um sequestrador de Ions superóxidos. Posteriormente, Cohen e Heikkila discutiram a capacidade de uma outra catecolamina, norepinefrina, de agir como sequestrador de íons superóxidos junto aos tẹ minais dos nervos simpāticos. Alēm disso, apresentaram evidèncias a favor da formação de radical hidroxila (HO') mediada por $\mathrm{O}_{2}^{\bar{a}}$ nesses nervos. A geração destes radicais está associada com fenōmenos tóxicos, isto é, a destruição de terminais dos nervos simpāticos, e a capacidade da norepinefrina em sequestrar ions superóxidos estaria associada então com a proteção destes termi nais de nervos.

\subsection{Aspectos Clínicos da Toxicidade por oxigênio}

A ocorrência de espécies ativadas de oxigênio em condições fisiológicas está atualmente bem aceita (Chance e colaboradores, 1979). As enzimas responsáveis pela proteção biológica contra níveis excessivos destas espécies são: SOD, GSH-Px e catalase.

$$
\begin{aligned}
& 2 \mathrm{O}_{2}^{\circ}+\mathrm{H}^{+} \stackrel{\mathrm{SOD}}{\longrightarrow} \mathrm{O}_{2}+\mathrm{H}_{2} \mathrm{O}_{2} \\
& \mathrm{GSH}+\mathrm{H}_{2} \mathrm{O}_{2} \stackrel{\text { GSH-Px }}{\longrightarrow}>\mathrm{GSSG}+2 \mathrm{H}_{2} \mathrm{O} \\
& 2 \mathrm{H}_{2} \mathrm{O}_{2} \stackrel{\text { catalase }}{>} 2 \mathrm{H}_{2} \mathrm{O}+\mathrm{O}_{2}
\end{aligned}
$$

A Figura 1.1 mostra esquematicamente 0 papel destas enzimas nos diferentes compartimentos subcelulares. Queremos ressal tar a ameaça que $\mathrm{HO}_{2}^{\circ}, \mathrm{H}_{2} \mathrm{O}_{2}, \mathrm{HO}^{\circ}$ e ${ }^{l_{0}}{ }_{2}$ poderiam representar pá ra a célula, caso sua produção in vivo não fosse controlada. 


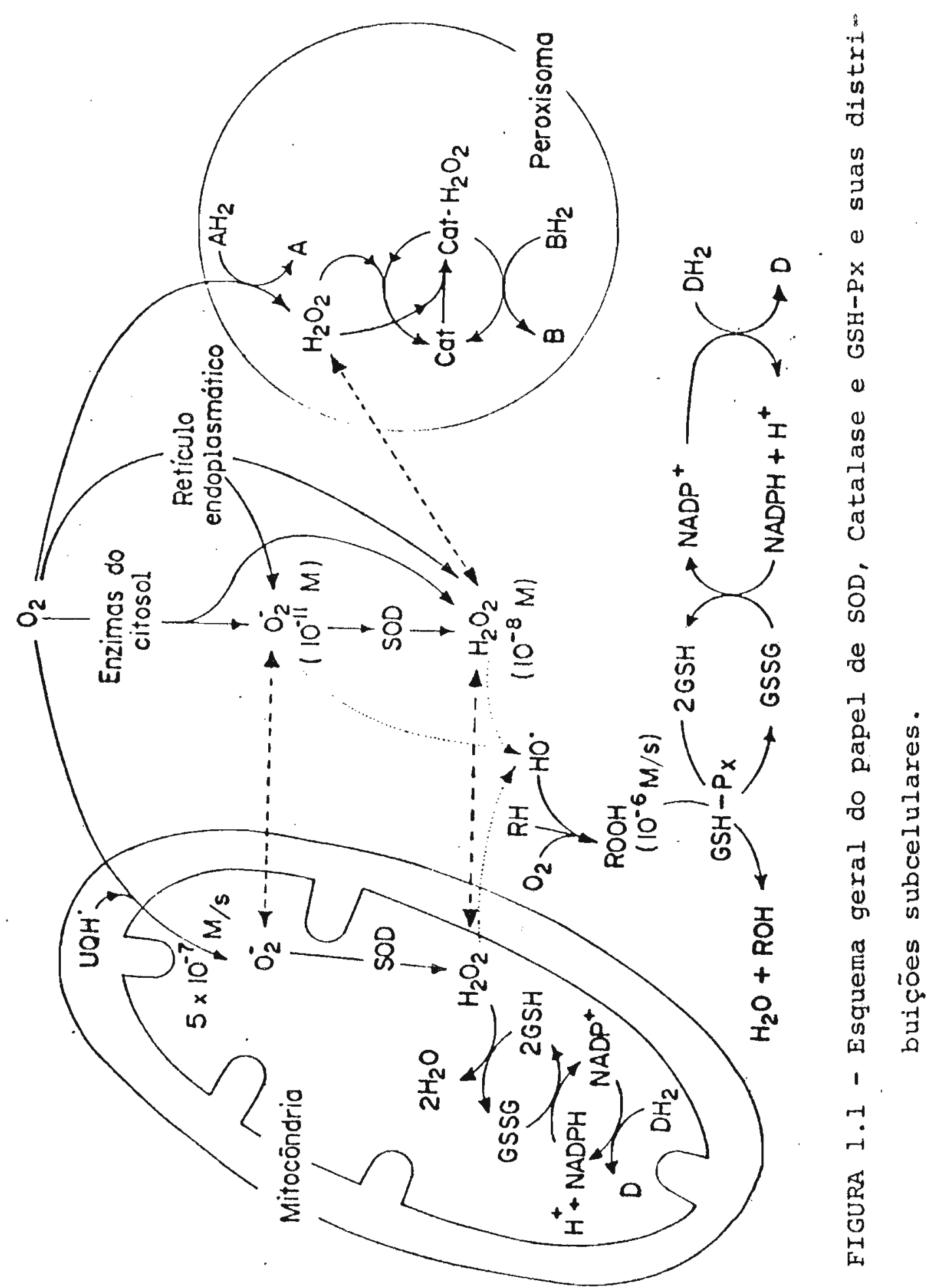


Tais espécies podem, entre outros malefícios, causar alterações no DNA, inativar enzimas e especialmente levar à peroxidação de lipídeos (vide Item sobre toxicidade). Diversos pesquisadores tem empenhado um enorme esforço (cerca de 60 trabalhos publicados em 1980/81) em relacionar o possível envolvimento de $\mathrm{O}_{2}^{\bar{\prime}}$, $\mathrm{H}_{2} \mathrm{O}_{2}$ e $\mathrm{HO}^{\circ}$ em diversos estados patológicos através de dosagens de SOD, catalase e glutationa peroxidase as quais, como vimos, constituem a principal linha de defesa do organismo contra a to xicidade destas espécies. A seguir, discutiremos algumas patolo gias onde os níveis destas enzimas mostraram-se alterados.

\subsubsection{Trisomia 21}

Os níveis de superóxido dismutase e de glutationa peroxida se em indivíduos com trisomia 21 é cerca de 1,5 vezes maior que em indivíduos normais (Michelson, 1977), enquanto que os níveis de catalase são completamente normais. Uma vez que o gene da su perōxido dismutase está localizado no cromossomo 21 , interpretou-se inicialmente a relação 1,5 como refletindo a dosagem do defeito genético. Porém como em diversas outras patologias, foram encontrados níveis altos de SOD, estes resultados não podem ser utilizados como prova dessa correlação.

1.3.2. Distrofia Muscular de Duchenne

A etiologia desta doença tem sido explicada como um defeito genético que afeta a estrutura e permeabilidade de membranas 
(Rowland, 1976). Encontrou-se em pacientes portadores desta doen Çã uma diminuição de $19 \%$ nos níveis de SOD em exitrōcitos. Os níveis de glutationa peroxidase apresentaram-se normais o que mostra que esta enzima provavelmente não está envolvida na etio logia de doença (Burri e colaboradores, 1980).

\subsubsection{B-Talassemia}

As talassemias são um grupo de anemias hereditārias nas quais a velocidade de síntese de uma das cadeias de hemoglobina é diminuída. As talassemias "major" e "minor" referem-se aos estaw dos homo e heterozigotos, respectivamente. O prefixo $\alpha$ ou $B$ designa qual cadeia de hemoglobina está sendo sintetizada com baixa velocidade.

Uma vez que a autoxidação de cadeias de hemoglobina podem levar a um aumento na produção de superóxido (Brunori e colabó radores, 1975) e consequentemente a umaumento dós níveis de peró xido de hidrogênio provenientes da dismutação destes radicais pela superóxido dismutase, Gerli e colaboradores (1980) investigaram o nível de SOD, catalase e GSH-Px em eritrócitos de indivíduos com $\beta$-talassemia. Foi observado um aumento significante no nível destas enzimas em indivíduos com $\beta$-talassemia "minor" e níveis similares ao normal em portadores de B-talassemia "major" que nunca tinha sofrido tranfusão sanguínea.

Pode-se então especular que a alteração nos níveis destas enzimas represente um mecanismo de defesa desenvolvido pelas cé 
lulas contra um aumento nos níveis de $\mathrm{O}_{2}^{-}$devido a autoxidação das cadeias de hemoglobina.

\subsubsection{Casos Psiquiátricos}

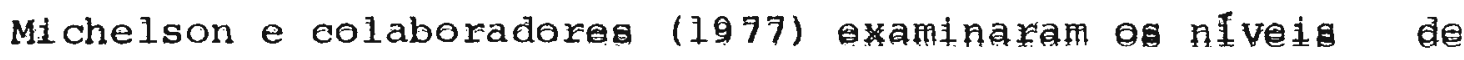
SOD e catalase em indivíduos brancos residentes na zona rural da Normandia, todos sofrendo de doenças mentais graves. Observa ram um aumento de cerca de $27 \%$ nos niveis de sod junto com um pequeno aumento (18\%) nos níveis de catalase.

O maior valor de SOD encontrado foi cerca de 1,6 vezes maior que o normal em um caso de psicose paranóide, o qual revelou tam bém um nível bastante alto de catalase (1,4 vezes maior que o normal). Os esquizofrênicos mostraram um aumento nos níveis de SOD de 1 a 1,5 vezes enquanto que em outras psicoses (maníacos-depressivos, alucinação crônica, síndrome de Korsakoff, delírio paranóico, debilidade mental, etc.) ccorre um aumento de 1,2 a 1,5 vezes para $S O D$ e níveis 1,0 a 1,4 vezes maiores de catala se.

Tais resultados podem sugerir que várias doenças mentais es tăo relacionadas com um aumento nos níveis de SOD e que inibido res desta enzima podem, eventualmente, serem utilizados na tera pia.

1.3.5. Pacientes com Hemólise Intravascular

Auclair e colaboradores (1981) dosaram os níveis de SOD em 
eritrócitos de pacientes com doenças malignas e sob regime poli quimioterápico. Neste grupo, alguns pacientes que estavam sofrendo de uma hemólise intravascular inexplicável exibiram um nivel extremamente baixo de SOD, enquanto que no caso de pacien tes que não apresentavam hemólise intravascular, os níveís desta enzima estavam normais.

De tais resultados, concluiram um possível envolvimento de $\mathrm{O}_{2}^{\overline{1}}$ como mediador de hemólise em células com deficiência de SOD. Esta hipótese era reforçada pelos dados de Goldgerb e Stem (1976), mostrando que um inibidor para SOD em células vermelhas, leva a um aumento na sensibilidade das mesmas à hemólise mediada por naftoquinona sulfonato, que é uma droga capaz de gerar $0_{2}^{\overline{-}}$ através de oxihemoglobina. Durān e colaboradores (1979), mosw traram a formação de moléculas no estado excitado em células vermelhas (fotoquímica no escuro) e seu envolvimento em hemólise.

1.3.6. Infecção Bacteriana

Uma vez que superóxido dismutase e glutationa peroxidase protegem o organismo contra efeitos tóxicos de $\mathrm{O}_{2}^{\bar{*}}$ e $\mathrm{H}_{2} \mathrm{O}_{2}$ gerados pelos leucócitos polimorfonucleares (PMNs) (Johnston, 1977), foram dosados os níveis destas enzimas em PMNs de crianças com infecçäo bacteriana e com hepatite infecciosa (Rister e colaboradores, 1979). Os resultados mostraram um aumento significativo na atividade de SOD enquanto que os níveis de GSH-Px permane ceram normais. Tendo em vista o papel de proteção de SOD contra 
toxicidade por espécies ativadas de oxigēnio, tais resultados podem colaborar muito para a compreensão dos aspectos patofisio lögicos de procesos inflamatórios.

\subsection{7. câncer}

Tem-se detectado uma diminuição nos níveis de superóxido dismutase em diversos tipos de tumores; concomitantemente, observou-se uma produção elevada de $0_{2}^{\overline{2}}$ nestas células (Oberley e colaboradores, 1979.

1.3.8. Efeito Terapêutico de SOD em Inflamações.

A utilização de SOD, injetada localmente, em diversas doenças inflamatórias foi recentemente relatada por Beckmann e Flohé (1981). A eficiência desta terapia foi estabelecida clarą mente em pacientes com osteoartrite inflamatória ativa na junta do joelho. Foi testada tambēm a ação de superōxido dismutase em casos de cistite interstical ou radioativa e observou-se uma me lhora em parâmetros como dor, frequência de micção e capacidade da bexiga.

1.3.9. Tratamento com SOD de necrose pós-radioterapia e da doença de Crohn

Como comentamos anteriormente raios $\mathrm{X}$ provocam danos em DNA e substâncias que sequestram $\mathrm{O}_{2}^{\overline{2}}$ protegem a célula contra esses 
efeitos. Em vista disto., Emerit e colaboradores (1981) exami naram o uso terapêutico de SOD em doença de Crohn e necrose induzida por radioterapia. Três casos de necrose radioterápica, devido a superdosagens, foram tratados durante um ano, dois meses e vinte dias respectivamente. Em todos estes casos os resul tados foram muito bons tendo sido comprovado a regressão da esclerose.

Tambēm foram tratados trēs casos de doença de Crohn's obtendo-se bons resultados à julgar pela regressão das lesões de pele. Entretanto tais resultados ainda são preliminares e devem ser confirmados.

\subsubsection{Diferenças Etnicas}

Michelson e colaboradores (1977), observaram níveis de SOD cerca de 53\% mais elevados em negros africanos residentes em Pa ris quando comparados com franceses brancos residentes na zona rural. Quanto aos níveis de catalase foram de cerca de 33응 maio res que o controle. Tais resultados podem significar a existên cía de uma diferença étnica marcante nos níveis destas enzimas. Entretanto tal afirmação pode não ser verdadeira uma vez que os indivíduos negros eram, há muito tempo, residentes na Paris metropolitana e não podem ser diretamente comparados com indivíduos da zona rural como veremos a seguir.

Com o intuito de reforçar possíveis diferenças étnicas nos niveis destas enzimas citamos também as dosagens de SOD feitas 
por Ueda e Ogata (1978) em eritrócitos de indivíduos japoneses onde os valores observados foram cerca de dez vezes maiores que os níveis relatados por Michelson e colaboradores (1977) em inđivîduos franceses.

1.3.11. Comparação entre Indivíduos da Zona Urbana e Rural

A superōxido dismutase de indivíduos brancos residentes em Paris é cerca de $38 \%$ mais elevada que em indivíduos brancos da zona rural e os níveis de catalase são $22 \%$ maiores (Michelson e colaboradores, 1977). Tais resultados, segundo Michelson, sugerem profundas diferenças no metabolismo de oxigênio entre a população rural e urbana.

\subsection{A Poluição em Vila Parisi}

Região conhecida como "Vale da Morte" entre os especialistas em problemas ambientais, Vila Parisi, bairro de Cubatão (SP). é a região mais poluída do Brasil. São 15 mil habitantes vivendo em casas de madeira contruídas num terreno alagadiço, abaixo do nível do mar, entre o leito da Rodovia Piaçaguera-Guarujá e os trilhos da Rede Ferroviária Federal.

Segundo dados fornecidos por técnicos da CETESB (artigo pu blicado no Jornal da Tarde 30/04/80), nesta região há emissão diária de mil toneladas de gases e partículas poluentes despeja dos na atmosfera por suas 30 indústrias químicas, siderúrgicas 
e de petróleo (Figura 1.2). O material particulado, nos dias de inversão tërmica, chega a duplicar o indice de 600 microgramas por metro cúbido de ar o qual, segundo a Organização Mundial de Saúde, começa a ser fatal.

Uma evidência dos danos provocados por esses altos índices de poluição é a vegetação queimada da Serra do Mar. A morte des ta floresta que recobre a serra, deixa imensas massas de terra e rochas expostas à ação das chuvas, o que leva à desmoronamentos ou deslizes das escarpas.

A situação do bairro è tão ruim que, em 1971, a Câmara dos Vereadores decidiu considerā-1o "aglomerado em extinção". Ali seria proibido executar qualquer obra pública, erguer qualquer casa. Em 1972, porém, a Câmara voltou atrās, legalizando a situação da Vila, desde então, ela nunca mais deixou de crescer.

A relação desnutrição versus poluição jamais foi estudada, assim como nunca foi feito qualquer estudo epidemiológico sobre a saúde de uma população às voltas com índices tão altos de poluentes no ar que respira. A Coordenadoria Mundial de Saúde registra para esta área índices impressionantes sobre tuberculose, bronquite, enfisema, asma crōnica, doenças cardiovasculares etc. . Sabe-se também, através da Sociedade Brasileira de Ecologia Hu-mana (órgão da Associação Médica Brasileira), que Cubatão é con siderada a capital das doenças respiratórias da América Latina.

A ocorrência de diversos casos de anencefalia e outras mal formações congênitas tem sido interpretada pelo Prof. Reinaldo Azoubel, da Faculdade de Medicina de Ribeirão Preto como decorrência provável dos altos índices de poluição. Tais estudos es- 


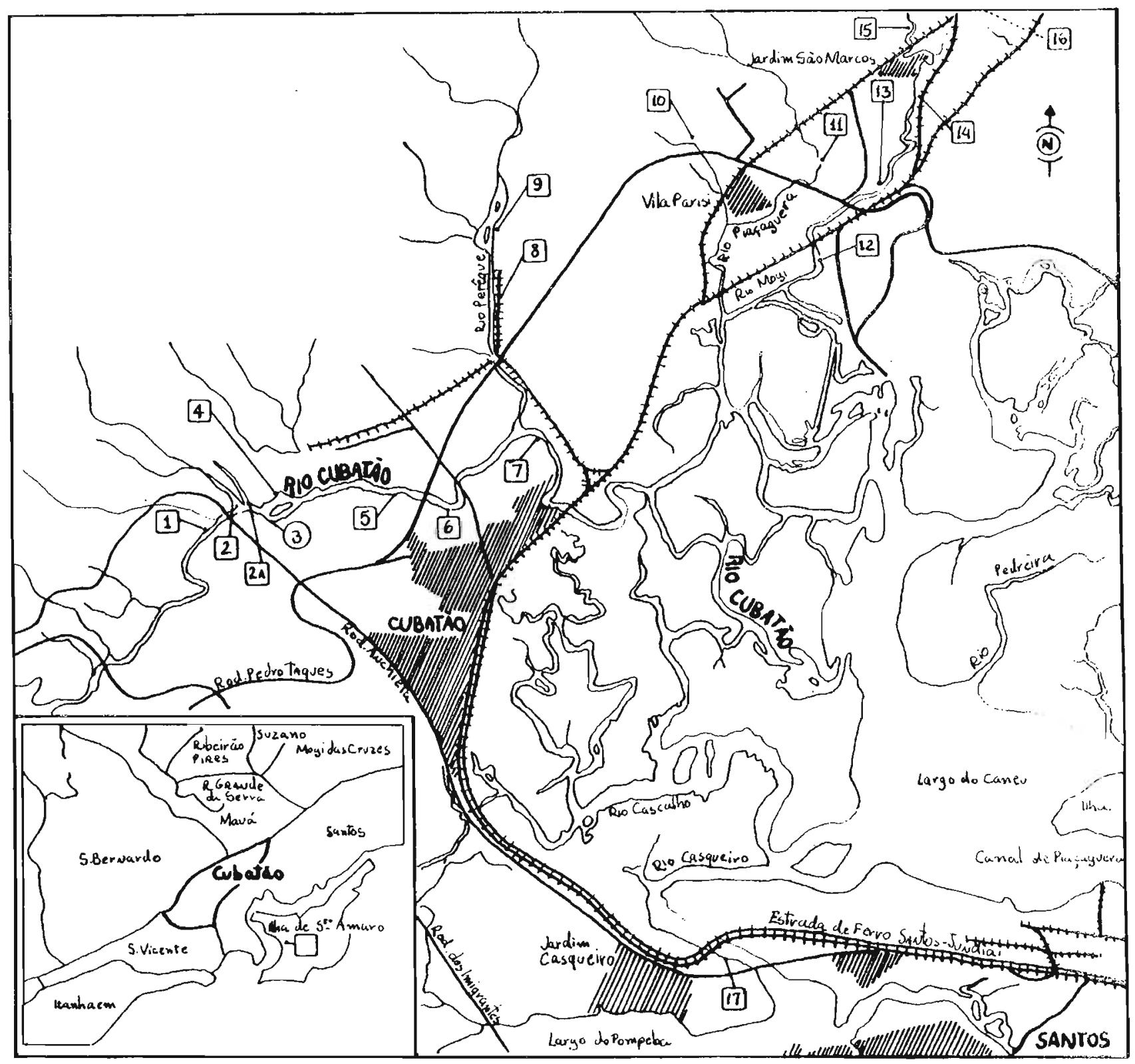

FIgURA 1.2 - Mapa da Região de Vila Parisi: 1. Cia. Santista de Pạ pel; 2. Usina da Light; 3. Estação de tratamento da Sapesp; 4. Ultrafértil S/A., Indústria e Comércio de Fertilizantes; 5. Refinaria Presidente Bernardes; 6 。 Companhia Brasileira de Estireno: 7. Carbocloro Clorogil e Engedor; 8. Alba-Adria S/A.; 9. Union Carbide do Brasil; 10. Companhia Petroquímica Brasileira; 11. Fertilizantes União; 12. Companhia Siderúrgica Paulis ta; 13. Manah S/A., Comércio e Indústria; 14. IAP, In dústria de Fertilizantes; 15. Ultrafértil; 16. Rhodia Indústrias Químicas e Têxteis S/A.; 17. Refrigerantes de Santos e 18. Complexo Dow Chemical. 
tão dependendo da construção urgente de um laboratōrio de teratogênese em Cubatão, o que jā foi oficialmente confirmado pela prefeitura local.

\subsection{Porfiria Aguda Intermitente}

A porfiria aguda intermitente (IAP) é uma desordem genética (dominante) caracterizada por um defeito na biossintese de heme (Marver e Schmid, 1972). Como consequência, advém excreção de excesso de precursores de porfirina na urina e, esporadicamente, ataques resultantes de disfunção neurológíca. IAP perten ce ao grupo das porfirias hepāticas hereditárias, onde tambēm se incluem a coproporfiria e porfiria "variegade". Nestes três casos, o fígado é o local principal no qual se manifesta o erro na biossíntese de heme, mas o defeito genético não se limita a este órgão tendo sido demonstrado, por exemplo, em outros tecidos como eritrócitos e fibroblastos.

Clinicamente a IAP se manifesta pela excreção urinária de altos níveis de ácido $\delta$-aminolevulinico (ALA) e porfobilinogênio ( $\mathrm{PBG}$ ) enquanto os níveis de porfirinas preformadas são normais. Assim pacientes com IAP não apresentam fotosensibilidade, em contraste com outras formas de porfiria onde ocorre formação excessiva, acúmulo e excre⿻⿱⺈口𧰨ç̃ão de porfirinas preformadas. A doen ça pode estar presente sob a forma latente (níveis normais de ALA e PBG na urina) por um período de tempo indefinido. Algumas pessoas com o defeito podem ter vida normal sem experimentar um ataque agudo (ou mesmo brando) de disfunção abdominal ou neuro- 
lógica. Quatro grupos de fatores "precipitantes" ou desencadeadores da IAP podem converter a doença latente em manifesta: cer tos medicamentos (drogas), certos esteróides (incluindo-se endô genos), regime alimentar e infecções.

Dores abdominais e sintomas mentais geralmente precedem os ataques agudos de IAP. O quadro clínico do ataque agudo pode va riar e o paciente ser então encaminhado a um gastroenterologista, cirurgião, neurologista ou psiquiatra. Nos ataques sérios, os pacientes, geralmente um adulto jovem, fica paralisado quase completamente da face aos pés, incapaz de se comunicar, deglutir ou respirar, com dor e consciente. A dor abdominal simula apendicite, obstrução intestinal e cólica renal.

\subsubsection{O Defeito Enzimático em IAP}

Para compreender a patogênese de IAP é importante entender a regulação da biossintese de porfirina e de heme (Fig. 1.3) (Meyer e Schmid, 1974).

Desde que ALA é o primeiro precursor específico da via e $\delta$-aminolevulinico sintetase (ALAS), a enzima que catalisa a etá pa limitante da velocidade de biossíntese de heme, o controle do processo global provavelmente ocorre ao nivel de ALAS. ALAS é uma enzima induzível de meia vida biológica relativamente cur ta. A síntese de ALAS no fígado é reprimida por heme e induzida por compostos de diferentes estruturas, incluindo-se agentes te rapêuticos, inseticidas, carcinogēnicos, esterōides endógenos e exógenos. De fato, alguns destes compostos precipitam ataques 


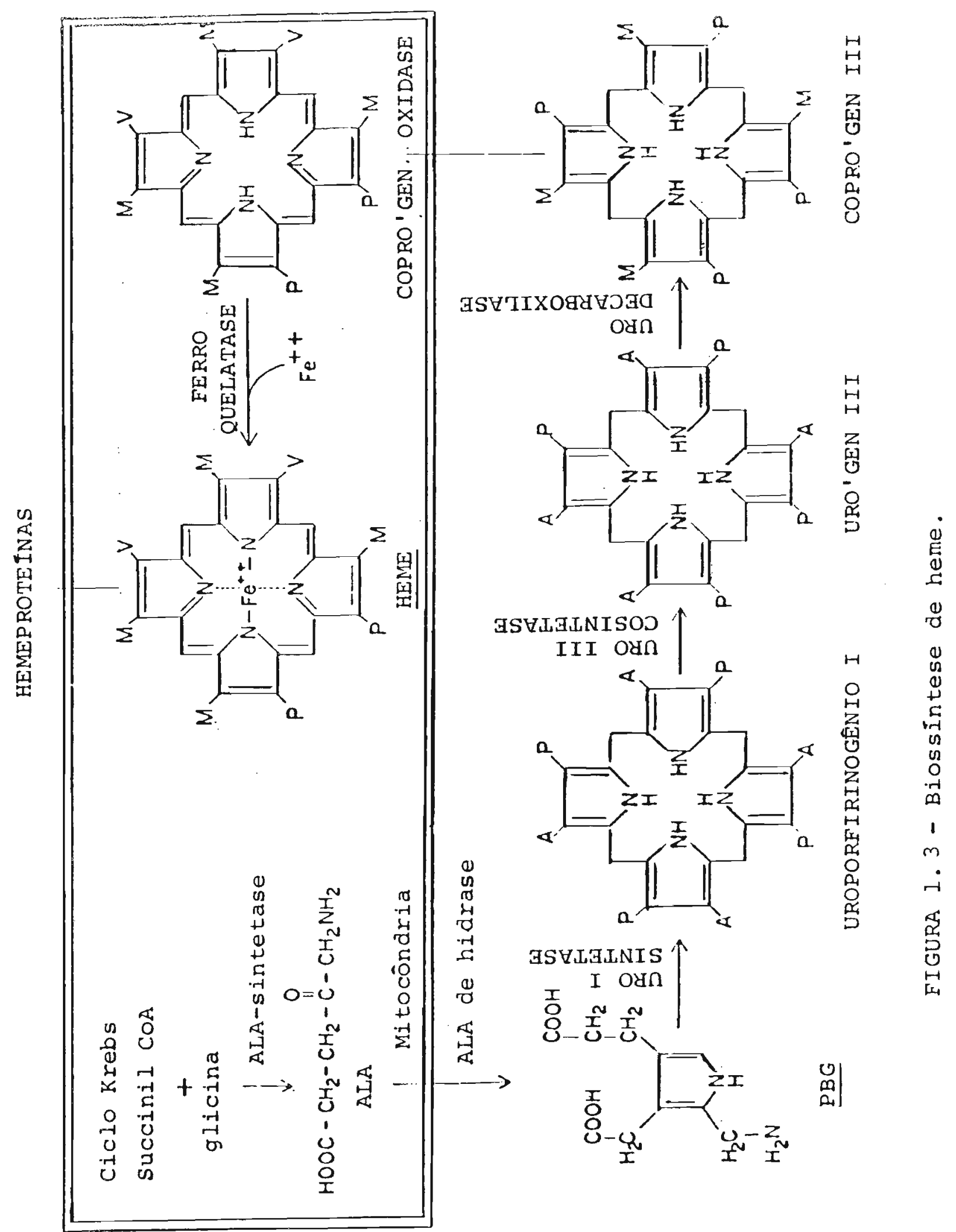


clínicos em pacientes com IAP latente. Assim, torna se aparente que indução mediada por drogas ou hormōnios e repressão mediada por heme da produção de ALAS no fígado são os mecanismos primários pelos quais a velocidade de síntese de heme é controlada. Entretanto, o aumento da atividade de ALAS não pode explicar per si o aumento da excreação de ALA e PBG pela urina sem um aumento concomitante na excreção de intermediários tetrapirrólicos que são formados após a etapa catalisada por URO-I sintetase. Estudos de Strand e colaboradores (1972) e de Miyagi e colabora dores (1971) demonstraram que, de fato, a atividade de URO-I sintetase em pacientes com IAP é diminuída de cerca de $65{ }^{\circ}$ no fígado e de $50 \%$ em eritrócitos. Estas observações sugerem que a redução na atividade de URO-I sintetase reflete a lesão genética primária em IAP, a qual, por sua vez, resulta na indução secundăria de ALAS devido à baixa produção de heme (Figura 1.4).

FIGURA 1.4

Succinil CoA

Glicina

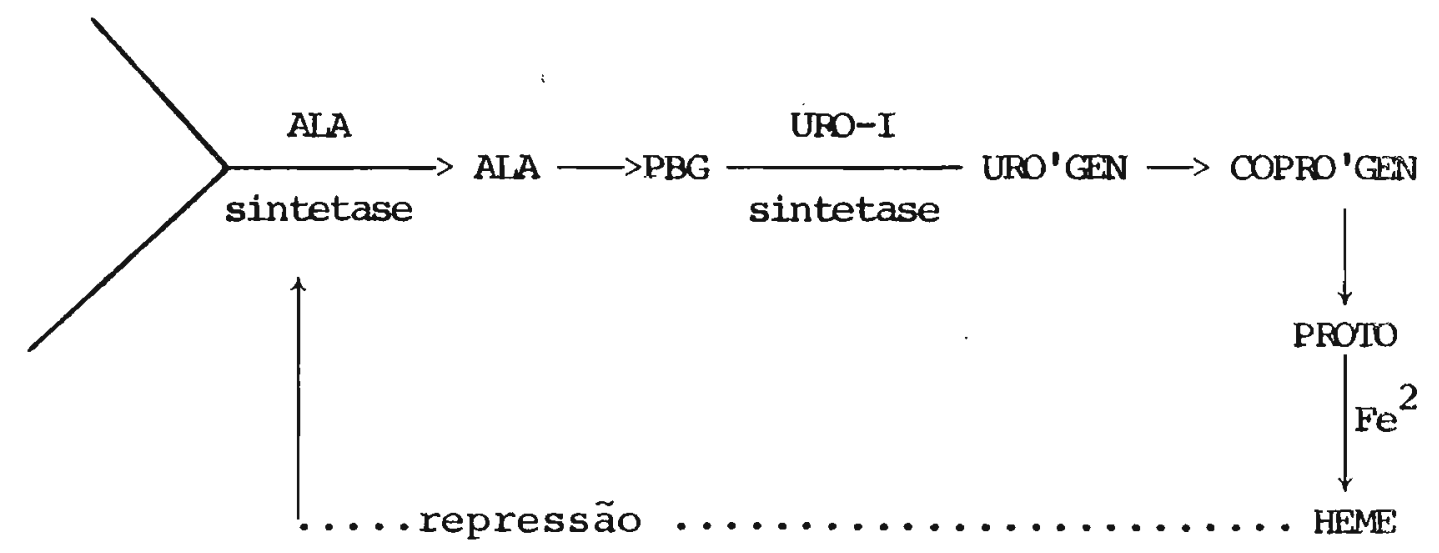

A relação destas anormalidades enzimáticas com as manifes tações neuropsiquiátricas da doença é desconhecida (Meyer e 
Schmid, 1974). Possíveis mecanismos sugeridos incluem: (1) baixos níveis de hemeproteínas ou acümulo de precursores nas células do sistema nervoso, causado pelo defeito genético, (2) efei to tóxico dos precursores ALA e/ou PBG formados no fígado e transportados para o sistema nervoso e (3) diminuição de metabó litos críticos ou acúmulo de substāncias neurotōxicas que, embo ra não estejam relacionados diretamente à síntese de heme, podem ser consequência da doença.

\subsubsection{Tratamento de IAP}

Atualmente, aceita-se o fato de que não existe cura para casos de IAP, entretanto, tem-se discutido intensivamente sobre uma forma confiável de prevenção e tratamento de ataques agudos. As duas terapias mais divulgadas são: dieta rica em carboidratos e administração intravenosa de hematina.

\subsubsection{Dieta rica em carboidratos}

Os açūcares têm sido amplamente utilizados no tratamento de ataques agudos de IAP. Nota-se uma redução na excreção de precursores porfirínicos após dieta rica em carboidratos (Goldberg e colaboradores, 1978, referência citada em Moore e colabo radores, 1980). Bonkowsky e colaboradores (1973) observaram uma redução na atividade de ALA-sintetase em ratos submetidos a esta dieta. Entretanto a resposta clínica e química para este tí po de tratamento é muitó pequena ou até mesmo nula (Xifra e colaboradores, 1980). 
1.5.2.2. Administração Intravenosa de Hematina

Este tipo de tratamento, está associado segundo Moore e co laboxadores (1980) com uma melhora clínica na maioria dos casos e com uma redução na excreção urināria de ALA.

A hematina está ganhando um lugar definitivo no tratamento de IAP, apesar de ainda existirem diversas controvérsias sobre seu uso, uma vez que as experiências com este tipo de terapia são ainda limitadas. Ela tem sido utilizada com relativo sucesso na prevenção de danos neurológicos permanentes em pacientes que sofreram ataques agudos. O mecanismo de ação de hematina no organismo ainda não está claro, entretanto, como em alguns pacientes sob este tratamento, observou-se uma diminuição na atividade de ALA sintetase e um aumento na atividade da URO-I sintetase, supõe-se que hematina reprime a atividade de ALA-sintetase reduzindo assim a produção total de precursores porfirinicos. Contudo tal explicação não esclarece como a atividade da URO-I sintetase aumenta nesses casos. 
Como vimos na Introdução desta tese, è hoje fato firmemente reconhecido, o papel de superōxido dismutase, catalase e glu tationa peroxidase (e talvez outras oxidases, oxigenases e pero xidases) no controle dos níveis intracelulares de $\mathrm{O}_{2}^{\bar{T}}, \mathrm{H}_{2} \mathrm{O}_{2}, \mathrm{HO}^{\circ}$, $l_{0_{2}}$ e outras espécies associadas. Tais espécies altamente reati vas são resultantes da redução parcial de oxigēnio molecular em vários processos bioquímicos. Níveis muito altos ou baixos de tais espécies representam séria ameaça ao metabolismo celular. Vários distúrbios podem daí se originar ("toxicidade por oxigènio"). Michelson e colaboradores (1977) foram os primeiros a in vestigar de forma intensiva e sistemātica as relações entre níveis anormais destas enzimas em eritrócitos e plaquetas e diferentes sindromes de origem genética ou não, especialmente em ca sos de debilidade mental e vārios casos psiquiātricos.

A potencialidade destes estudos tem dispertado enorme inte resse em um grande número de pesquisadores, como atestam, por exemplo, o "Symposium on Oxygen Free Radicals and Tissue Damage" (Ciba Foundation), realizado em Londres (1978) e a "International. Conference on Molecular Mechanisms of Oxygen Toxicity" em Paris $(1980)$.

Em linhas gerais, propomo-nos nesta tese a:

a) contribuir com o esclarecimento dos mecanismos bioquími cos responsáveis pelo dramātico quadro neuropsiquiátrico que se 
manifesta em portadores de porfiria aguda intermitente (IAP), es tudando a possibilidade de toxicidade por espécies ativadas de oxigênio como causa dos sintomas. A abordagem experimental consiste na determinação das enzimas superóxido dismutase, glutationa peroxidase e catalase no hemolisado de portadores sintomá ticos e assintomáticos da doença e de um grupo de controle sadio. Esta proposta de trabalho se justifica plenamente ao consi derar-se as seguintes características da doença:

(i) distúrbios psíquicos antecedendo ao ataque agudo, sugerindo a possibilidade de comprometimento da biossíntese de neuromediadores e de acümulo de endohalucinógenos;

(ii) defeito na via biossintética de heme, o qual é grupo prostético de várias proteínas e enzimas, envolvendo transporte e metabolização de oxigênio molecular, entre elas, cata lase, peroxidases e triptofano dioxigenase; e

(iii) uso terapêutico de hemina, espécie envolvida em vários prô cessos onde $\mathrm{H}_{2} \mathrm{O}_{2}, \mathrm{HO}_{2}^{\circ}$ e $\mathrm{HO}^{\circ}$ estão presentes.

b) comparar os níveis eritrocitários destas tres enzimas de moradores de Vila Parisi (Cubatão, SP), talvez a comunidade mais poluída do País, com aqueles da cidade de são Paulo (controle), com o intuito de se procurar estabelecer relação entre poluição atmosférica e metabolismo de oxigênio. E sabiāo que di versos tipos de poluentes atmosféricos levam à oxidação de oxihemoglobina a methemoglobina ou induzem a autoxidação de hemoglobina, culminando com a lise de eritrócitos. 


\section{MATERIAIS E MÉTODOS}

\subsection{Abreviações:}

$\begin{array}{ll}\text { HRP } & \text { - peroxidase de rábano silvestre. } \\ \text { GSH-PX } & \text { - glutationa peroxidase. } \\ \text { GSH } & \text { - glutationa reduzida. } \\ \text { GSSG } & - \text { glutationa oxidada. } \\ \text { GSSG-R } & - \text { glutationa redutase. } \\ \text { NBT } & \text { - "nitroblue tetrazolium". } \\ \text { SOD } & \text { - superóxido dismutase. } \\ \text { IAP } & - \text { porfiria aguda intermitente. }\end{array}$




\subsection{Enzimas e Reagentes}

As enzimas e reagentes listados abaixo foram usados tal co mo adquiridos dos fornecedores:

Sigma Chemical Co: acetato de sódio, ácido $\delta$-aminolevulíni co, t-butil hidroperóxido, catalase de fígado bovino, glutationa redutase, glutationa reduzida, peroxidase de rabanete (Tipo VI), "kit" para dosagem de hemoglobina, 1-metionina, NADPH, nitro "blue" tetrazolium, porfobilinogênio, superóxido dismutase bovina, superóxido dismutase de sangue humano.

Carlo Erba: bihidrogenofosfato de potássio, ferricianeto de potāssio, hidrogeno fosfato de potássio, hidrōxido de sōdio, perōxido de hidrogênic.

E. Merck, D: ácido acético, cloreto de sódio, etilenodiamin tetracetato (sal sódico), iodeto de potássio, riboflavina, tetrahidrofurano.

Mallinckrode Chemical Works: cianeto de potássio.

Todas as soluções foram preparadas com água bidestilada e as concentrações, a menos que especificado, calculadas por pesa gem.

\subsection{Aparelhagem}

Espectrofotômetro Zeiss, Modelos DMR-10 e DMR-21

Espectrofluorímetro Perkin-Elmer MPF-4

Fotômetro tipo Hastings-Mitchell, construído no laborató 
rio, provido de fotomultiplicadora tipo 1P28.

Centrífuga Sorvall superspeed $\mathrm{SS}-1$

Potenciōmetro Metrohm, tipo E-510

Iâmpada Mineralight UVL-22

\subsection{Mëtodos}

\subsubsection{Purificação de Luminol}

Foi utilizada uma modificação do método sugerido por Drew e Perman (1937): uma solução concentrada de luminol em solução 5 $\mathrm{NaOH}$ foi resfriada a $0^{\circ} \mathrm{C}$ em banho de gelo. Os cristais resul tantes foram dissolvidos em água e reprecipitados com adição de ácido acético 10\%. A pureza do luminol foi controlada pelo espectro ultravioleta em tetrahjdrofurano $\left(\varepsilon\right.$ em $360 \mathrm{~nm}=7,9 \times 10^{3}$ $\mathrm{M}^{-1} \mathrm{~cm}^{-1}$ ).

\subsubsection{Determinação de Peróxido de Hidrogênio}

As dosagens de peróxido de hidrogênio, feitas segundo cotton e Dunford (1973), baseiam-se na oxidação de iodeto por $\mathrm{H}_{2} \mathrm{O}_{2}$, ca talisada por peroxidase. O ensaio ( $2 \mathrm{ml})$, realizado em cela de quartzo, contém: $0.2 \mathrm{ml}$ de solução de peróxido de hidrogênio, HRP (peroxidase de răbano silvestre) $0,5 \times 10^{-8} \mathrm{M}, \mathrm{KI} 0,05 \mathrm{M}$ e tampão acetato $0,1 \mathrm{M}, \mathrm{pH} 3,8$. A reação é iniciada pela adição de KI na forma sólida e mede-se então a absorbância do íon $\mathrm{I}_{3}{ }^{-}$ formado a $353 \mathrm{~nm}\left(\varepsilon_{\mathrm{I}_{3}}-=2,55 \times 10^{4} \mathrm{M}^{-1} \mathrm{~cm}^{-1}\right)$. 
3.4.3. Padronização de Catalase

A atividade específica da catalase comercial (padrão) foi avaliada por meio de medidas da velocidade de desaparecimento de peróxido de hidrogēnio, observada pelo decréscimo da absorbância a $240 \mathrm{~nm}$ a $25^{\circ} \mathrm{C}$ :

$$
2 \mathrm{H}_{2} \mathrm{O}_{2} \longrightarrow 2 \mathrm{H}_{2} \mathrm{O}+\mathrm{O}_{2}
$$

Sendo esta uma reação de primeira ordem na concentração de peróxido de hidrogênio, a velocidade de decomposição é diretamente proporcional à concentração de enzima.

3.4.4. Determinação de Hemoglobina

Os valores de hemoglobina foram estimados pelo método de Drabkin e Austin (1935). De acordo com esta técnica, a hemoglobina total, em pH alcalino, é rapidamente convertida em cianohe moglobina que é determinada pela leitura de absorbância a $540 \mathrm{~nm}$. Diluições de soluções de cianohemoglobina padrão com solução de Drabkin foram usadas para a preparação da curva de calibraçăo (Fig. 3.1).

o sistema é constituído de solução padrão de methemoglobiná humana $(0,0 ; 1,0 ; 2,0 ; 3,0 \mathrm{ml})$ e solução de Drabkin (100 par tes bicarbonato de sódio, 20 partes ferricianeto de potássio e 5 partes cianeto de potássio em $1000 \mathrm{~m} 1$ de ăgua): $3,0,2,0,1,0$, e $0 \mathrm{ml}$. 
Na padronização do produto foi usado o seguinte coeficiente de extinção molar:

$\varepsilon($ cianohemoglobina $)=44,0 \times 10^{3} \mathrm{M}^{-1} \cdot \mathrm{cm}^{-1}$

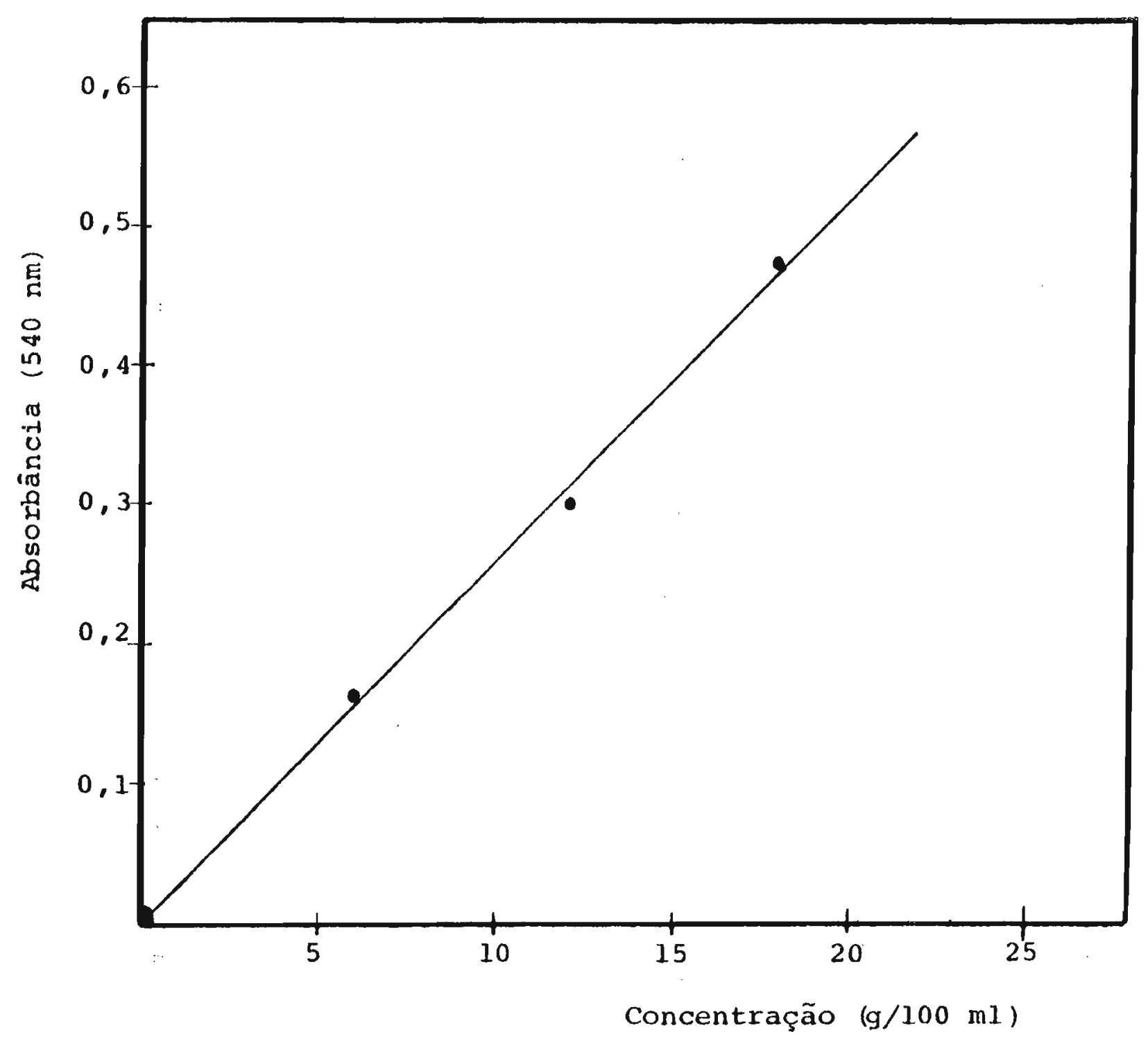

FIGURA 3.1 - Curva de calibração de hemoglobina. 
3.4.5. Dosagem de Catalase via Inibição da Reação Quimiluminescente do Luminol.

A dosagem de catalase é baseada em medidas de intensidade de emissão oriunda da reação quimiluminescente entre luminol e $\mathrm{H}_{2} \mathrm{O}_{2}$ residual de um sistema de incubação catalase- $\mathrm{H}_{2} \mathrm{O}_{2}$ (Maral e colaboradores, 1977).<smiles>Nc1cccc(C(=O)[O-])c1C(=O)Oc1cccc(C(=O)[O-])c1C(=O)O</smiles>

A cubeta de reação contēm $10 \mu \mathrm{g}$ de HRP em $3 \mathrm{ml}$ de ELTA $10^{-4} \mathrm{M}$, luminol $10^{-4} \mathrm{M}$ em tampão fosfato $0,1 \mathrm{M} \mathrm{pH} 7,8$. A reação é iniciada pela injeção de $1 \mathrm{ml}$ da mistura de incubação $13 \mathrm{ml}$ de $\mathrm{H}_{2} \mathrm{O}_{2}$ $2,1 \times 10^{-5} \mathrm{M}$ em tampão fosfato $10^{-2} \mathrm{M} \mathrm{pH} 7,8$ e catalase; a incu bação é feita a $25^{\circ} \mathrm{C}$ por $20 \mathrm{~min}$.) e em seguida é dosado o peróxido de hidrogênio residual.

A curva de calibração de catalase (figura 3.2) mostra linearidade entre o logarítmo da intensidade de luz emitida pelo luminol e a concentração de $\mathrm{H}_{2} \mathrm{O}_{2}$ residual. A reação foi iniciada por injeção rāpida de solução estoque de $\mathrm{H}_{2} \mathrm{O}_{2}$ no frasco de reação contido no interior do fotômetro e exposto à fotomultiplica dora, uma vez que a reação é muito rápida, com metade de luz tô tal emitida em um minuto. Tal processo dificulta a homogeniza- 


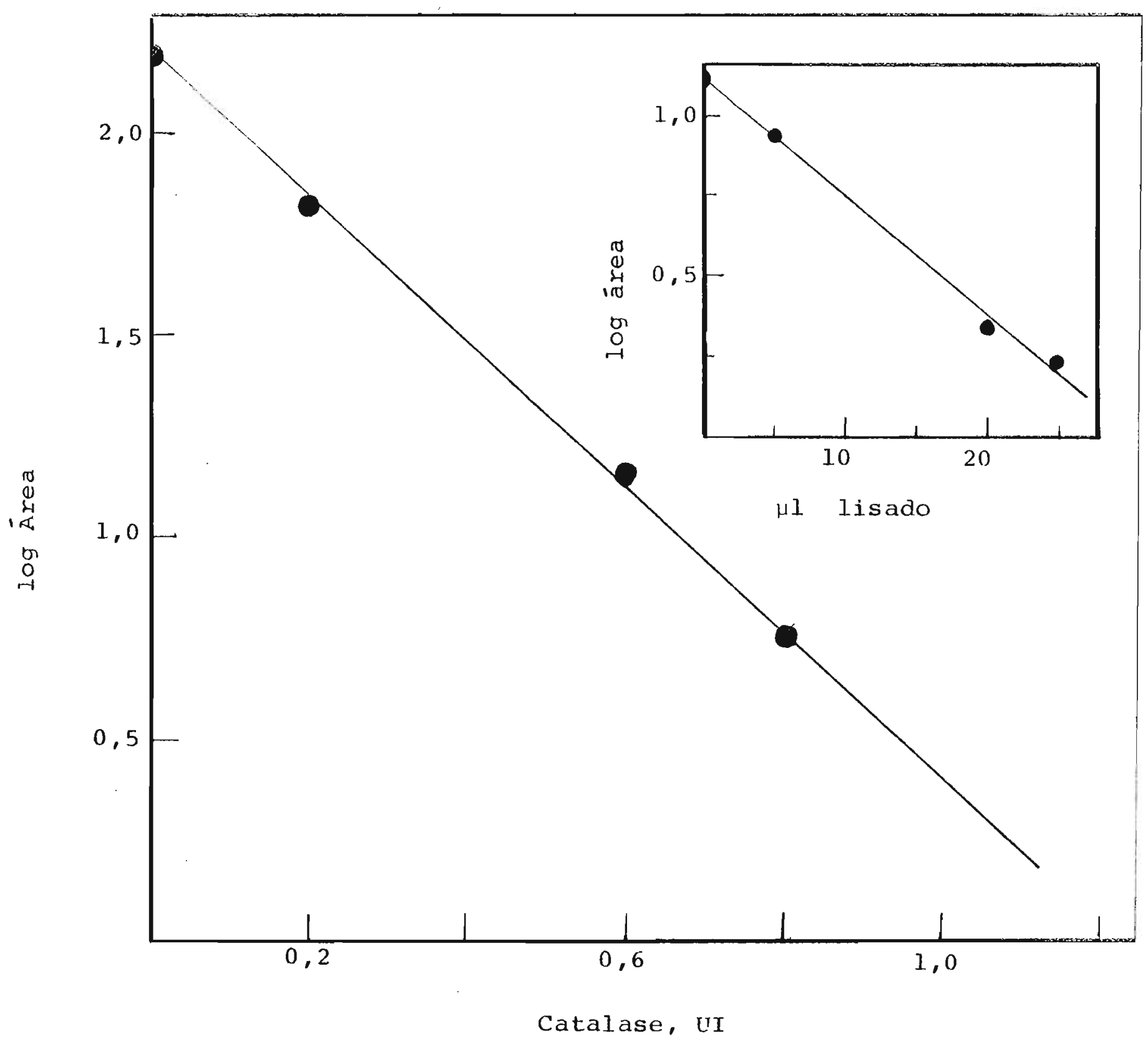

FIGURA 3.2 - Curva de calibração para as dosagens de atividade de catalase. 
ção da mistura, impedindo que a dosagem seja baseada em medidas de intensidade máxima e tornando necessário o uso de medidas de emissäo total. Thërèse Wilson (1976) já havia comentado este inconveniente do uso de medidas baseadas na reação quimilumines cente do luminol.

Eliminamos a possibilidade de interferentes no lisado afetarem a linearidade de resposta, testando diferentes concentraÇões de lisado no sistema completo (Fig. log area $x \mu 1$ hemoli sado inserida na Figura 3.2).

Todas as medidas foram feitas em duplicata, tendo-se cons tatado uma reprodutibilidade dentro de $15 \%$

\subsubsection{Dosagem de Glutationa-Peroxidase}

o mëtodo de dosagem é baseado em medidas da velocidade de oxidação da glutationa na forma reduzida (GSH) por um hidroperó xido, na presença de glutationa peroxidase (GSH-Px). As medidas são feitas acoplando-se a este sistema à redução imediata da glutationa oxidada (GSSG) por NADPH na presença de glutationa redutase (GSSG-R) .

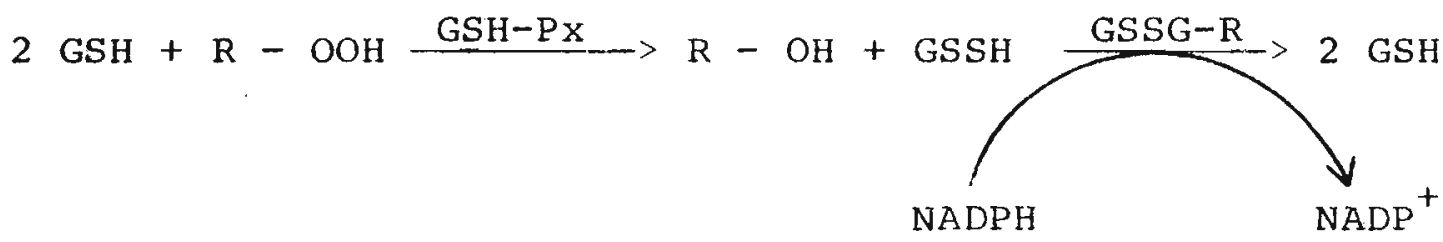

A velocidade de formação de GSSG é medida seguindo-se o de créscimo da absorbância do NADPH a $340 \mathrm{~nm}\left(\varepsilon=6,22 \times 10^{3} \mathrm{~mol} 1^{-1}\right.$ $\mathrm{cm}^{-1}$ ). 


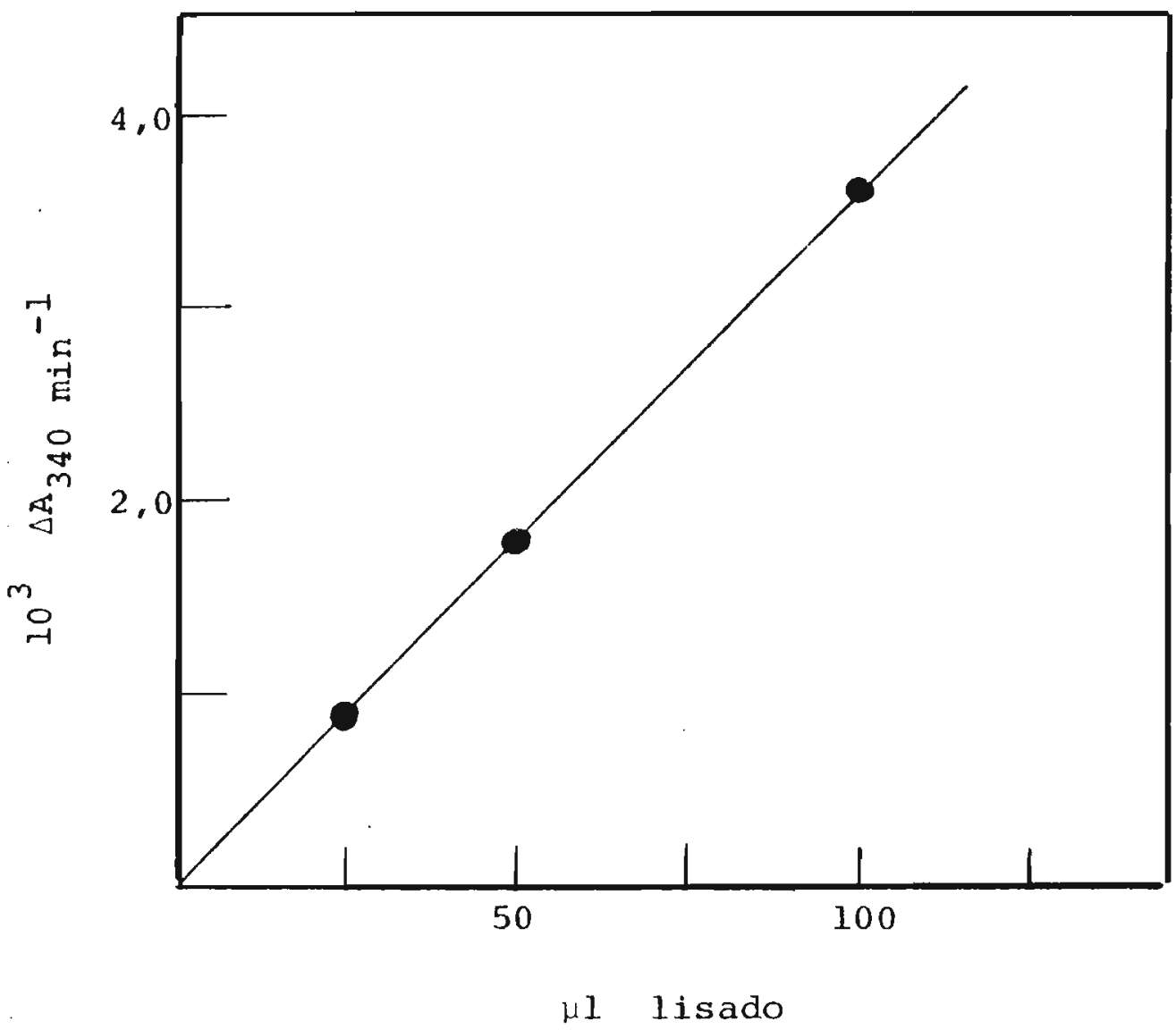

FIGURA 3.3 - Curva de calibração para as dosagens de atividade de GSH-Px. 
A mistura de reação $(3 \mathrm{mI})$ contēm NADPH $2 \times 10^{-4} \mathrm{M}$, GSH $10^{-3} \mathrm{M}$, hidroperóxido de t-butila $10^{-3} \mathrm{M}, 3 \mathrm{U} . \mathrm{I}$ de GSSG-R e $100 \mu 1$ de lisado de sangue (Michelson e colaboradores, 1977). As medidas são feitas à $37^{\circ} \mathrm{C}$.

A figura 3.3 mostra a linearidade de resposta do sistema de dosagem de glutationa peroxidase com diferentes concentrações de lisado de sangue.

Todas as amostras foram dosadas em duplicada, tendo sido encontrado um limite de erro de cerca de $15 \%$ entre as medidas.

Segundo Zakowski e Tappel (1978), NADPH age como inibidor de GSH-Px. Decidiu-se entãc testar esta possibilidade, aumentan do de $50 \%$ a concentração de NADPH na mistura de reação: não se observou nenhuma alteração na atividade da GSH-Px.

3.4.7. Determinação da Atividade de Superóxido Dismutase via Inibição da Redução de "Nitro Blue Tetrazolium"

A atividade da superóxido dismutase é medida segundo método descrito por Maral e colaboradores (1977), por meio da inibição da redução do nitroblue tetrazolium (NBT) por $\mathrm{O}_{2}^{-}$gerado duran te a reoxidação de riboflavina fotoreduzida:

$$
\begin{aligned}
& \mathrm{F} \longrightarrow \mathrm{FH}_{2} \quad \lambda_{\max }^{\mathrm{abs}}(\mathrm{F})=365 \mathrm{~nm} \\
& \mathrm{FH}_{2}+\mathrm{O}_{2} \longrightarrow \mathrm{FH}+\mathrm{HO}_{2} \\
& 2 \mathrm{FH}^{\cdot} \longrightarrow \mathrm{F}+\mathrm{FH}_{2} \\
& \mathrm{NBT}_{\mathrm{Ox}}+\mathrm{O}_{2}^{-} \longrightarrow \mathrm{NB}_{\text {red }}+\mathrm{O}_{2} \lambda_{\text {max }}^{\mathrm{abs}}\left(\mathrm{NBT}_{\text {red }}\right)=560 \mathrm{~nm}
\end{aligned}
$$


o sistema de dosagem é constituído de riboflavina $2 \times 10^{-6} \mathrm{M}$, metionina $10^{-2} \mathrm{M}, \mathrm{KCN} 2 \times 10^{-5} \mathrm{M}$ e NBT $1,7 \times 10^{-4} \mathrm{M}$ em tampão fosfato $5 \times 10^{-2} \mathrm{M} \mathrm{pH} 7,8$. A esta mistura, na cubeta de reação ( $2 \mathrm{ml}$ ), adiciona-se 10 !l de lisado de sangue, e a solução Einal è irradiada a $365 \mathrm{~nm}$ utilizando-se uma lâmpada ultravioleta Mineralit UVL-22, acoplada a um banho termostatizado à $25^{\circ} \mathrm{C}$ cuja parede é transparente ao UV. A cela de reação é fixa da dentro do banho a uma distância de $2 \mathrm{~cm}$. O témpo de irradiação é ajustado de forma tal que seja observado em um branco, na ausência de SOD, um aumento na absorbância a $560 \mathrm{~nm}$ de 0,20 a 0,21 .

A figura 3.4. mostra linearidade da redução de NBT com a adição de diferentes concentrações de lisado de sangue.

A tabela 3.1 mostra que as medidas de absorbância, feitas através do método de inibição da redução do NBT via SOD, são confiáveis dentro de um limite de erro de cerca de $5 \%$.

TABELA 3.1. - Precisão das medidas de inibição de redução do NBT promovida por SOD de hemolisados.

\begin{tabular}{c|c|c}
\hline $\begin{array}{c}\text { AMOSTRA DE } \\
\text { HENOLISADO }\end{array}$ & MEDIDA & ABSORBÂNCIA $560 \mathrm{~nm}$ \\
\hline \multirow{2}{*}{ A } & 1 & 0,110 \\
& 2 & 0,115 \\
\hline \multirow{2}{*}{ B } & 1 & 0,135 \\
& 2 & 0,135 \\
\hline \multirow{2}{*}{ C } & 1 & 0,140 \\
\hline & 2 & 0,145 \\
\hline D & 1 & 0,152 \\
& 2 & 0,150 \\
\hline
\end{tabular}


54.

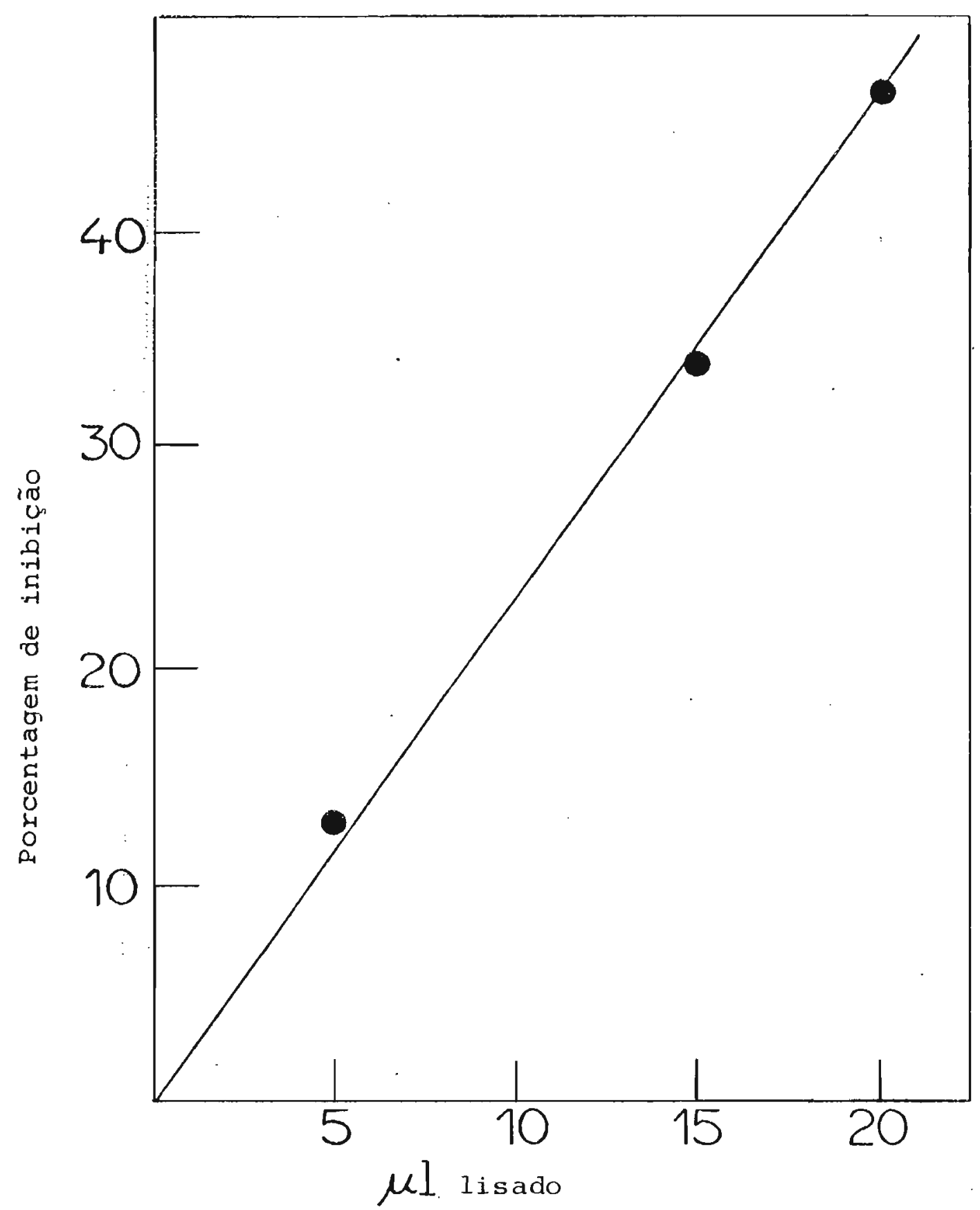

FIGURA. 3.4 - Curva de calibração para as dosagens de atividade de SOD. 
$\mathrm{Na}$ literatura, são descritos outros métodos de dosagem de SOD, tais como:

i métodos enzimáticos: geração de superóxido pelo siste ma da xantina oxidase, tendo como substrato xantina ou hipoxantina e como detectores: citocromo c (Salin e McCord, 1974), nitroblue tetrazolium (Beauchamp e Fridovich, 1971) e oxidação de sulfito (Tyler, 1975).

ii - métodos fotoquímicos: produção de superóxido pela reo xidação espontânea de flavina fotoreduzida e, acoplado para deteç̧ão, o sistema de redução do citocromo c (Massey e colaboradores, 1969).

iii. métodos químicos: por exemplo, a autoxidação de epine frina a adrenocromo (Misra e Fridovich, 1972).

3.4.8. Preparação das Amostras de Sangue

Cerca de $4 \mathrm{ml}$ de sangue são coletados dos doadores, utilizando-se o sistema "Vacutainer" da Becton Dickinson que tem citrato como anticoagulante.

A- Para as Dosagens de SOD e Catalase

Dois $\mathrm{ml}$ de sangue são centrifugados durante $10 \mathrm{~min}$. a $3000 \mathrm{~g}$ e o soro removido por sucção. Então adiciona-se água destilada ( $1 \mathrm{ml}$ ) e os eritrócitos são resuspensos por agitação e lisados por duas horas a $4^{\circ} \mathrm{C}$ (volume do lisado, $2 \mathrm{ml}$ ). Para um volume de $1,8 \mathrm{ml}$ deste lisado adiciona-se $0,9 \mathrm{ml}$ de uma mistura de clo rofórmio-etanol $(3: 5)$ e $0,3 \mathrm{ml}$ de àgua para precipitar a hemo- 
globina, a qual é centrifugada a $3000 \mathrm{~g}$ por $10 \mathrm{~min}$. Superóxido dismutase é estimada diretamente neste lisado e a catalase determinada após diluição de 100 vezes do lisado.

\section{B- Para a Dosagem de Glutationa Peroxidase}

Um ml de sangue é centrifugado por $10 \mathrm{~min}$. a $3000 \mathrm{~g}$ e o soro removido. Os eritrócitos são então lavados 3 vezes com solução de $\mathrm{NaCl} 0,9 \%$ e lisados com a adição de $1 \mathrm{ml}$ de água segui da de congelamento a $-70^{\circ} \mathrm{C}$ e rāpido aquecimento. Estes lisado é então diluído a uma concentração de $5 \mathrm{~g}$ de hemoglobina por $100 \mathrm{ml}$ e então misturado com um volume igual de $4 \times 10^{-3} \mathrm{M}$ ferricianeto de potássio, $2 \times 10^{-2} \mathrm{M} \mathrm{KCN}$ em $0,1 \mathrm{M}$ tampão fosfato $\mathrm{pH} 7,0$. 
Apresentamos, a seguir, os resultados das dosagens de SOD, GSH-Px, catalase e os níveis de hemoglobina em eritrócitos de individuos normais, pacientes portadores de IAP e indivíduos re sidentes em Vila Parisi. Os métodos analiticos e as curvas de calibração utilizados encontram-se detalhadamente descritos no Capítulo 3 deste trabalho. As atividades enzimáticas foram expressas por $\mathrm{ml}$ de sangue e por grama de hemoglobina. Entretanto, uma vez que uma das maiores fontes de $\mathrm{O}_{2}^{\overline{1}}$ em eritrócitos é a de gradação da hemoglobina, a expressão dos resultados por grama de hemoglobina ē, segundo Michelson e colaboradores (1977) a mais precisa.

Para a avaliação da significância das diferenças encontradas entre os casos estudados e o controle, relatamos junto aos histogramas os resultados de teste estatístico não paramētrico de Kolmogorov-Smirnov para duas amostras. Essa prova atesta se duas amostras foram extraídas da mesma população (ou de popu lações com a mesma distribuição). A prova bilateral é sensĩvel a qualquer diferença das quais se extrairam as amostras, diferenças de locação, na dispersão, na assimetria, etc.. A prova de Kolmógorov-Smirnov visa a concordāncia entre dois conjuntos de valores amostrais. Se as duas amostras foram efetivamente ex traídas da mesma população, então é de se esperar que as distribuiçōes cumulativas de ambas as amostras sejam bastante próxi- 
mas uma das outras, acusando apenas desvios aleatórios em relação à distribuição da população. Se as distribuições cumulativas das duas amostras são muito diferentes ou distantes uma da outra em qualquer ponto, isto sugere que as amostras provêem de populaçöes distintas.

\subsection{Grupo Controle}

As amostras de sangue utilizadas na elaboração do grupo con trole foram obtidas de doadores aparentemente sadios, de ambos os sexos, com idade entre 17-40 anos, residentes na cidade de São Paulo, alunos da Escola de Preparação de Soldados da Polícia Militar e estudantes, professores e funcionários do Institụ to de Química da USP. A tabela 4.1 contém as atividades de SOD, GSH-Px e de catalase, bem como os níveis de hemóglobina, nos eri trócitos do grupo controle. Nas figuras 4.1 a 4.6 , são apresentados os histogramas correspondentes e os dados estatísticos re ferentes a valor médio das medidas $(X)$ e desvio padrão da média (Sx) .

4.2. Indivíduos portadores de IAP

4.2.1. Caracterização dos pacientes e estōria da doença

Relatamos, a seguir, um resumo das características pessoais de cada paciente, quadro clínico e tipo de tratamento recebido. O diagnóstico de IAP foi efetuado no Hospital das clíni cas da Universidade de São Paulo e baseado em exames clínicos 
e/ou laboratoriais, sob a responsabilidade do Dr. Paulo E. Marchiori do Departamento de Neurologia clinica daquele hospital.

CASO 1 - Indivíduo assintomático, pai da paciente caso 3.

CASO 2 - Mulher, 25 anos, branca e solteira. Foi internada em setembro de 1978, relatando que após tomar medicação anti-inflamatória motivada por dores lombares, apresentou vômitos aquosos, persistentes por sete dias. No oitavo dia de inter nação começou a referir "fraqueza nas pernas", perda súbita de visão, crises convulsivas tipo grande mal e emissão de urina "cor de Vinho do Porto". O exame neurológico atesta confusão mental, tetraparesia com hiperreflexia global e redução do campo visual. Foi tratada com Clonazepan, germe de trigo, dieta hi percalörica, com melhora progressiva do campo visual. Obteve al ta hospitalar com redução moderada do campo visual que se normą lizou três meses após. Vem sendo mantida com Clonazepan 2mg/dia, não tendo mais surtos desde então. A paciente realizou a pesqui sa de URO-I sintetase em 01/09/81, na ausência de surto, que mostra $51 \mathrm{nmol} / 100 \mathrm{~g}$ de hemácias/h (normal: 38-74 nmol/lo0g de hemācias $/$ h) .

CASO 3 - Mulher, 20 anos, branca e solteira. Foi internada em 25 de junho de 1980 , referindo dores lombares bilaterais e disestesias na face lateral da coxa e perna direita. Não eliminava urina vermelha. O exame físico nessa época foi normal. Em 30 de junho de 1981 voltou a ser internada com as mesmas que xas. Apresentava disestesias no membro inferior direito. URO-I= sintetase $=30 \mathrm{nmol} / 100 \mathrm{~g}$ de hemācias $/ \mathrm{h}$ (normal: $38-74 \mathrm{nmol} / 100 \mathrm{~g}$ 
de hemācias/h). Foi tratada com clopromazina obtendo melhora clínica em 15 dias.

CASO 4 - Homen, 28 anos, preto e solteiro. Internado em 03 de janeiro de 1981, há um dia com dor abdominal em cölica, vômitos, perda de força nos membros inferiores, oito horas após ter desvio de rima bucal sem perda de consciência. Apresentava evacuações diarréicas. Tem um irmão que aos 20 anos apresentou quadro semelhante. A urina apresentava-se avermelhada. Teste de Watson-Schwartz positivo. O exame neurológico atestou paresia crural predominantemente distal, flacidez, tremores vibratórios, reflexos miotáticos distais diminuídos nos membros superiores. Patelares e aquileus diminuidos simetricamente. Parestesias em membros inferiores. Palestesia diminuida nos membros superiores e inferiores. Artrestesia conservada. Apresentou tromboflebite no membro superior esquerdo. Tem quatorze irmãos sendo que todos estão vivos. A mãe è viva e saudável. Segundo o paciente, seu pai morreu de "dor de cabeça".

CASO 5 - Mulher, 27 anos, branca e casada. Em janeiro de 1978, quatro meses após dar a luz, durante a menstruação, co meçou a ter dores abdominais em cólica, nāuseas e vômitos. Foi medicada com antiespasmódico sem apresentar melhora. Investigada radiologicamente nada revelou. Acompanhou o quadro obstipação intestinal sonolência, palavras mal articuladas, frases descone xas. Urina côr de "vinho do Porto". O pai com 61 anos è saudāvel, a mãe com 56 anos é nervosa. Teve uma irmã que faleceu aos 23 anos com IAP. Apresentcu sensação de parestenia nos membros inferiores. 'Teste de Watson-Schwartz positivo. 
CAso 6 - Mulher, 27 anos, branca e casada. Em abril de 1979 começou a apresentar queda acentuada de cabelos que instalou-se de maneira abrupta. Em maio do mesmo ano começou a sen tiv dor em choque de grande intensidade na extremidade do pé es querdo, dor esta acompanhada de dormência que ascendeu até a raíz do membro inferior esquerdo de maneira progressiva ao cabo de mais ou menos dois meses. Em outubro de 1979, teve sensação de dormência no pé direito que também ascendeu para a raíz do respectivo membro em algumas semanas. Ainda nessa data teve epi sódio de instalação aguda de dores dispersas pelio corpo, acompa nhadas de falta de ar. Em novembro teve quadro alucinatório de instalação aguda que perdurou por apenas um dia e teve remissão espontânea. Foi internada em hospital em dezembro de 1979 com quadro de vômitos incoercíveis. Prova de Watson-Schwartz positi va.

CASO 7 - Mulher, 26 anos, branca e solteira. Foi internada em 30 de agosto de 1978. Aos 15 anos de idade começou a ter dor lombar intensa, irritabilidade e crises convulsivas tônico-clônicos generalizadas. Medicada com Fenobarbital 100mg/dia e Hidantoinato $300 \mathrm{mg} /$ dia não teve melhora. Hā um ano apresentava urina de côr avermelhada, disúria, dor lombar e abdominal sendo submetida a cirurgia vesical. Seis meses apös teve quadro infeccioso apresentando fraqueza sūbita nos quatro membros que a impedia de segurar objetos e deambular. Há um mês julho de 1978 apresentava retração nas mãos e intensificação das crises dolorosas abdominais que se tornaram constantes. Apresentava dores generalizadas, períodos de diarréia, vômitos e emagrecimento acentuado hã 6 meses. Pai falecido e mãe sem antecedentes seme- 
Ihantes. Um irmão apresentava crises convulsivas mas morreu por afogamento. Exame neurológico: flexão máximas das mãos, flexão dos antebraços sobre os braços; extensão dorsal dos pës; não se mantëm em pë. Tetraparesia distal, hipotonia da musculatura; re flexos profundos presentes e simëtricos com exceção dos açuilia nos e flexores dos dedos. Hiposensibilidade tátil e térmica em luva de cano longo e nos membros inferiores até um terço proximal da coxa. Teste de Watson-Schwartz positivo. Enquanto foi tratada com Carbamarepin apresentou crises convulsivas, dores abdominais intensas e urina avermelhada. Foi tratada com hemati na em 12 de abril de 1978, apresentou melhora discreta do quadro. Em seguida utilizou-se clorozepan 4mg, a partir de então houve melhora gradativa de fundo clínico, voltando a deambular porén com melhora da tetraparesia tendo vida ütil e ativa. Até outubro de 1981 não apresentou novas crises.

CASO 8 - Homem, 25 anos, branco e solteiro. Foi internado com estōria anterior de 15 dias com dores abdominais e cólicas lombares. Uma semana após mostrou formigamento e fraqueza nas pernas, ascendente, e dificuldade de micção associada a uri na avermelhada. Este quadro evoluiu para falta de ar e dificuldade para realizar movimentos. O exame neurológico apontou tetra paresia, arreflexia generalizada e sensibilidade tátil. Teste de Watson-Schwartz positivo. Foi medicado com hematina $250 \mathrm{mg} / 12$ ho ras por seis dias. Houve sinais de remissão do surto, porém a melhora da motilidade atingiu o máximo em quatro meses.

Caso 9 - Homem, 48 anos, branco e casado. Foi internado em maio de 1980 com episödios repetidos de dores abdominais em 
cölicas, difusas e emissões de urina "cor de vinho do Porto". Obstipação intestinal associada. o quadro revelou tambēm dores em ambos os membros inferiores. Apresentou dores abdominais difusas à palpação profunda. Foi tratado com clorpromazina 200mg/ dia, obtendo alta hospitalar duas semanas após.

CASO 10 - Mulher, 23 anos, branca e solteira. Foi internada em 13 de agosto de 1980 revelando haver dado à luz há dois meses. Uma semana após, apresentou nāuseas e vômitos alimentares sem outros comemorativos. Quinze dias antes da interna ção apresentou cólica abdominal, difusa, irradiando-se para a região lombar com emissão de urina avermelhada. Hā três dias tị nha febre e não se mantinha mais em pé. Exame genitourinário: e missão de urina avermelhada. Antecedentes familiares: tio pater no morreu de causa indeterminada. Abdome: flácido, doloroso à palpação profunda no hipogástrico. Exame neurológico revelou confusão mental, tetraparesia assimétrica, arreflexia universal, mobilidade do diafragma diminuida, paresia do 99 e 108 pares cranianos, com déficit de motilidade do pálato mole. Teste de Watson-Schwartz positivo. O quadro evoluiu rapidamente para insuficiência respiratória sendo entubada e colocada em respiração assistida. Recebeu tratamento com hematina (180 mg de 12/12h) em 14 de maio de 1980 atẻ 15 de maio de 1980. Tomou 4 infusões, revelando nesse periodo discreta melhora dos movimentos do membro superior direito. Em 16 de maio de 1980, durante a realização de traqueostomia teve parada cardiorespiratória irreversivel. CAso 11 - Homem, 25 anos, pardo e solteiro. Foi internado em 27 de março de 1981 com quadro de dores abdominais em cô 
licas, difusa, urina côr clara e fraqueza nos quatro membroe há . um mês. Dores nas massas musculares, tetraparesia assimétrica, aneflexa generalizada. ALA: 5,9 (normal 1,3-7,0) $\mathrm{mg} / \mathrm{d}$. PBG: 5,2 (normal 1-1,5) mg/d. URO porfirina: $263 \mathrm{mg} / 1400 \mathrm{ml}$ (nomal 1-25mg/ $1400 \mathrm{ml}$ ) . Coproporfirina: $183 \mu \mathrm{g} / 1400 \mathrm{ml}$ (normal 20-200 $\mu \mathrm{g} / 1400$ $\mathrm{m} 1)$. Foi medicado com hematina $240 \mathrm{mg}(4 \mathrm{mg} / \mathrm{kg})$ em 11 doses e be tabloqueadcres. Não obteve melhora com hematina, foi reprimida a atividade da doença.

CASO 12 - Mulher. Em janeiro de 1981, sofreu cirurgia de urgên cia com diagnóstico de prenhez ectópica, apresentava dor abdominal e amenorréia. Recebeu alta com fraqueza nos mem bros inferiores, dificuldade a deambulação e urina escura. Evoluiu para fraqueza nos membros inferiores e dificuldade para se alimentar e pentear o cabelo. Como sentia dificuldade para respirar, foi internada em unidade de terapia intensiva por dez dias. Exame de Watson-Schwartz positivo. Exame neurolögico revelou te traparesia de predomínio proximal nos membros superiores mas tam bëm com acometimento distal (extensãc dos punhos e dedos bilate ralmente. Exames laboratoriais: $A L A=1,5(1,3-7,0) \mathrm{mg} / \mathrm{d}, \mathrm{PBG}=4,3$ $(1,0-5,0) \mathrm{mg} / \mathrm{d}$, , coproporfirina $=360(20-200) \quad \mu \mathrm{g} / \mathrm{d} .$, uroporfirina $=$ $140 \mu \mathrm{g} / 1400 \mathrm{ml}(1-25 \mu \mathrm{g} / 1400 \mathrm{ml})$.

4.2.2. Níveis de SOD, GSH-Px e Catalase em Portadores de IAP.

A tabela 4.2 contēm as atividades de SCD, GSH-Px e catalase, bem como os níveis de hemoglobina nos eritrócitos de pacien te com IAP. As figuras 4.7 a 4.12 ,mostraram a distribuição das dosa 
gens enzimáticas em eritrōcitos de indivíduos portadores de IAP. Estão representados, em linha tracejada, os histogramás controle para melhor visualização das diferenças encontradas. Não estão mostrados os valores da média e desvio padrăo dessas medidas, uma vez que esses cālculos não têm significado estatỉstico dado ao tamanho da amostragem $(n=12)$. Junto às legendas de ca da figura são indicados os resultados do tratamento estatístico não paramétrico de Komogorov e Smirnov.

Só foram discriminados os indivíduos assintomáticos daquêles em crise aguda no histograma que mostra a atividade de SOD/g hemoglobina, pois, só neste caso foi encontrada diferença signi ficativa entre esses dois grupos de pacientes.

Testou-se o efeito de ALA $\left(1,0 \times 10^{-4}, 2,0 \times 10^{-4}, 5,0 \times 10^{-4}\right.$ e $\left.1,0 \times 10^{-3} M\right)$ e de $\operatorname{PBG}\left(1,0 \times 10^{-4}, 2,5 \times 10^{-4}, 5,0 \times 10^{-4} \mathrm{e}\right.$ $1,0 \% 10^{-3}$ M) na atividade enzimática de SOD bovina, da SOD $e$ GSH-Px presentes no hemolisado: não foram observadas quaisquer alterações nas atividades.

4.3. Individuos Residentes em Vila Parisi

Coletou-se amostras de sangue de doadores de ambos os sexos residentes em Vila Parisi, com idade entre 15-45 anos. Todos os doadores residem na vila há mais de um ano, são aparentemente sadios e não estavam sob tratamento com medicamentos. 
A tabela 4.3 contém as atividades de SOD, GSH-Px e catalase, assim como os niveis de hemoglobina em eritrócitos de residentes de Vila Parisi. Nas figuras 4.13 a 4.18 , são apresentaAcs os histogramas correspondentes e os dados estatisticos refe rentes a valor médio das medidas $(\bar{x})$ e desvio padrão da média $(\mathrm{Sx})$. Junto às legendas de cada figura são indicados os resulta dos do tratamento estatístico não paramētrico de kolmogorov-Smirnov. 
PABELA 4.1 - Níveis de SOD, GSH-PX, catalase e hemoglobina em eritrōcitos de indivíduos normais ${ }^{a}$.

\begin{tabular}{|c|c|c|c|c|c|c|c|}
\hline \multirow{2}{*}{ CASO } & HEMOGLOBINA & \multicolumn{2}{|c|}{ SOD } & \multicolumn{2}{|c|}{ GSH-Px } & \multicolumn{2}{|c|}{ CATALASE } \\
\hline & $\mathrm{g} / 100 \mathrm{ml}$ & $\mathrm{U} / \mathrm{g} \quad \mathrm{Hb}$ & $\mathrm{U} / \mathrm{ml}$ & $\mu \mathrm{M} / \mathrm{g} \quad \mathrm{Hb}$ & $\mu \mathrm{M} / \mathrm{m} 1$ & $\mu \mathrm{g} / \mathrm{g} \mathrm{Hb}$ & $\mu \mathrm{g} / \mathrm{ml}$ \\
\hline 1 & 14,8 & 513 & 76 & - & - & - & - \\
\hline 2 & 14,4 & 539 & 77 & - & - & 2392 & 354 \\
\hline 3 & 12,3 & 510 & 63 & - & - & 2222 & 320 \\
\hline 4 & 13,2 & 561 & 74 & - & - & 3003 & 396 \\
\hline 5 & 13,6 & 425 & 58 & - & - & - & - \\
\hline 6 & 13,6 & 501 & 68 & - & - & - & - \\
\hline 7 & 12,3 & 375 & 46 & - & - & - & - \\
\hline 8 & 14,8 & 493 & 73 & 10,0 & 1,5 & 1198 & 177 \\
\hline 9 & 13,2 & 498 & 66 & 15,0 & 2,0 & 1555 & 205 \\
\hline 10 & 13,2 & 498 & 66 & 10,0 & 1,3 & 922 & 121 \\
\hline 11 & 13,6 & 634 & 86 & 16,0 & 2,2 & 1099 & 149 \\
\hline 12 & 12,6 & 530 & 67 & 12,0 & 1,5 & 3426 & 452 \\
\hline 13 & 12,8 & 419 & 54 & 9,0 & 1,2 & 1957 & 250 \\
\hline 14 & 12,9 & 354 & 46 & 10,0 & 1,3 & 1658 & 212 \\
\hline 15 & 14,2 & 325 & 46 & 11,0 & 1,6 & 1540 & 216 \\
\hline 16 & 12,0 & 583 & 70 & 7,7 & 0,9 & 2608 & 313 \\
\hline $\begin{array}{l}17 \\
18\end{array}$ & $\begin{array}{l}15,0 \\
13,2\end{array}$ & $\begin{array}{l}404 \\
590\end{array}$ & $\begin{array}{l}61 \\
78\end{array}$ & $\begin{array}{l}14,0 \\
13,0\end{array}$ & $\begin{array}{l}2,1 \\
1,7\end{array}$ & $\begin{array}{l}1958 \\
2372\end{array}$ & $\begin{array}{l}297 \\
313\end{array}$ \\
\hline 19 & 14,0 & 500 & 70 & - & - & 2152 & 299 \\
\hline 20 & 14,8 & 527 & 78 & - & - & 2209 & 327 \\
\hline 21 & 14,0 & 557 & 78 & 23,0 & 3,2 & 2140 & 306 \\
\hline 22 & 15,8 & 596 & 94 & - & - & 2597 & 410 \\
\hline 23 & 15,5 & 477 & 74 & 7,0 & 1,1 & 2603 & 403 \\
\hline 24 & 15,8 & 584 & 92 & 13,0 & 2,0 & 2550 & 403 \\
\hline 25 & 17,0 & 434 & 74 & 7,0 & 1,2 & 2370 & 403 \\
\hline 26 & 15,8 & 468 & 74 & 10,0 & 1,6 & 2550 & 403 \\
\hline 27 & 17,2 & 535 & 92 & 10,5 & 1,8 & 2587 & 445 \\
\hline 28 & 16,2 & 455 & 74 & 7,7 & 1,2 & 2362 & 328 \\
\hline 29 & 16,8 & 547 & 92 & 8,0 & 1,4 & 2588 & 445 \\
\hline 30 & 17,0 & 507 & 87 & - & - & 2526 & 424 \\
\hline 31 & 15,8 & 386 & 61 & 16,0 & 2,5 & 2069 & 327 \\
\hline 32 & 13,2 & - & - & - & - & 2635 & 348 \\
\hline 33 & 15,1 & - & - & - & - & 2280 & 344 \\
\hline 34 & 13,9 & - & - & - & - & 2602 & 361 \\
\hline 35 & 13,1 & - & - & - & - & 2496 & 327 \\
\hline 36 & - & - & - & - & - & - & - \\
\hline 37 & 16,7 & - & - & 12,0 & 2,0 & - & - \\
\hline
\end{tabular}

a) Os métodos de dosagem utilizados estão descritos no capítu103 . 
TAEELA 4.2 - Níveis de SOD, GSH-PX, catalase e hemoglobira em eritrócitos de indivíduos normais e portadores de IAP assintomāticos e em crise aguda.

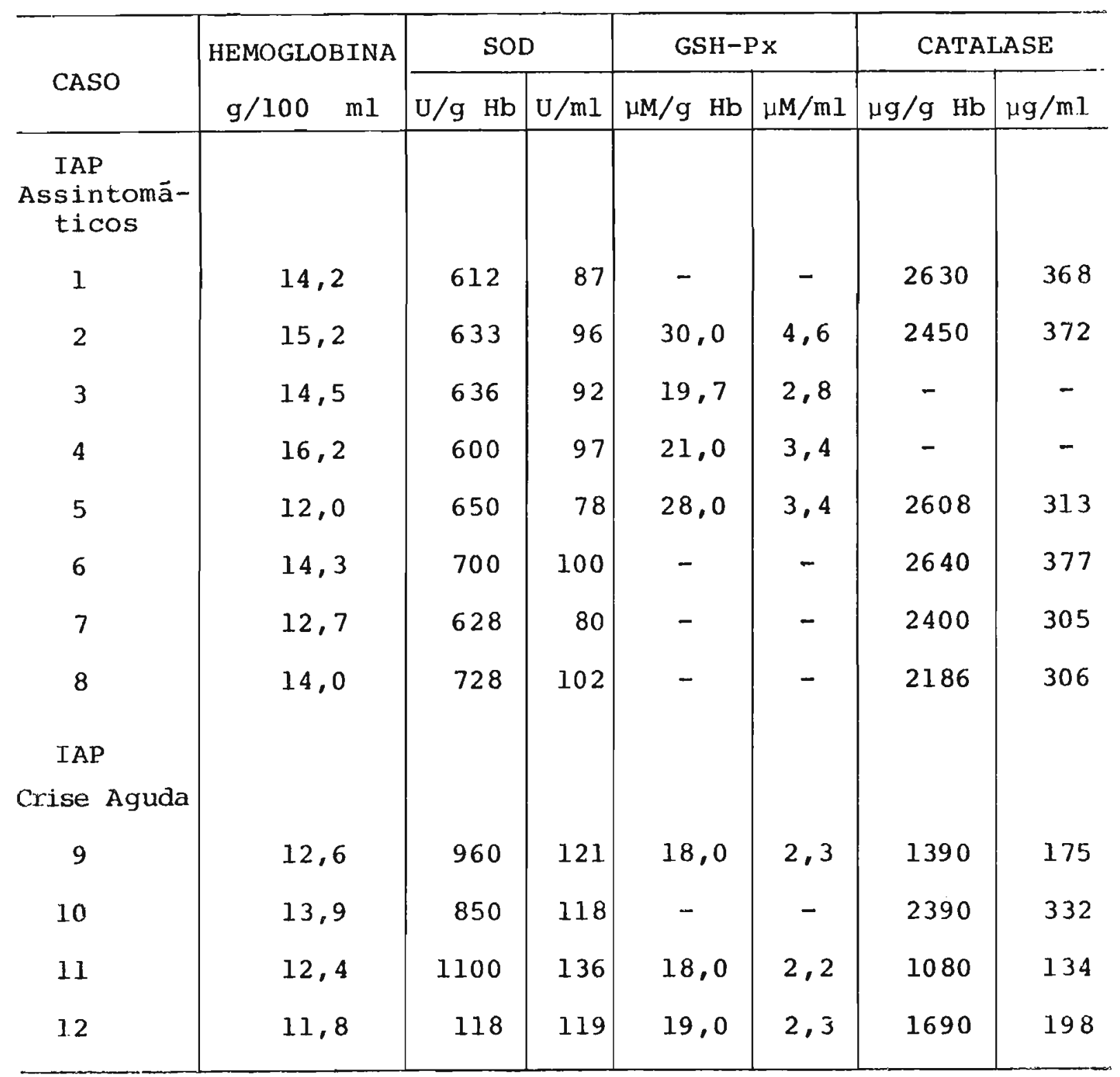


TABELA 4.3 - Niveis de SOD, GSH-PX, catalase e hemoglobina em eritrōcitos de individuos residentes em yila Parisi.

\begin{tabular}{|c|c|c|c|c|c|c|c|}
\hline \multirow{2}{*}{ CASO } & \multirow{2}{*}{$\begin{array}{l}\text { HEMOGLOBINA } \\
\mathrm{g} / 100 \mathrm{ml}\end{array}$} & \multicolumn{2}{|c|}{ SOD } & \multicolumn{2}{|c|}{$\mathrm{GSH}-\mathrm{Px}$} & \multicolumn{2}{|c|}{ CAYALASE } \\
\hline & & $\mathrm{U} / \mathrm{g} \mathrm{Hb}$ & $\mathrm{U} / \mathrm{ml}$ & $\mu \mathrm{M} / \mathrm{g} \quad \mathrm{Hb}$ & $\mu \mathrm{M} / \mathrm{mil} \mathrm{I}$ & $\mu \mathrm{g} / \mathrm{g} \quad \mathrm{Hb}$ & $\mu \mathrm{g} / \mathrm{ml}$ \\
\hline 1 & 18,8 & 477 & 90 & 31,0 & 5,8 & 962 & 180 \\
\hline 2 & 18,8 & 558 & 105 & 31,0 & 5,8 & - & - \\
\hline 3 & 14,2 & 580 & 82 & 34,0 & 4,8 & - & - \\
\hline 4 & 14,2 & 632 & 90 & 41,0 & 5,8 & 2155 & 306 \\
\hline 5 & 18,5 & 632 & 117 & 26,0 & 4,8 & 3459 & 639 \\
\hline 6 & 17,8 & 663 & 118 & 20,0 & 3,6 & 2110 & 376 \\
\hline 7 & 13,4 & 670 & 90 & 31,0 & 4,1 & 776 & 104 \\
\hline 8 & 13,8 & 702 & 97 & 24,0 & 3,3 & 756 & 104 \\
\hline 9 & 13,0 & 746 & 97 & 26,0 & 3,4 & 2353 & 306 \\
\hline 10 & 15,1 & 788 & 119 & 23,0 & 3,5 & 3225 & 487 \\
\hline 11 & 15,1 & 788 & 119 & 27,0 & 4,0 & 2580 & 390 \\
\hline 12 & 14,8 & 804 & 119 & 28,0 & 4,1 & 2816 & 417 \\
\hline 13 & 14,8 & 806 & 119 & 26,5 & 4,0 & 2186 & 323 \\
\hline 14 & 14,4 & 826 & 119 & 21,0 & 3,0 & 2898 & 417 \\
\hline 15 & 13,9 & 856 & 119 & 26,0 & 3,6 & 2602 & 417 \\
\hline 16 & 13,9 & 856 & 119 & 23,0 & 3,2 & 2604 & 362 \\
\hline 37 & 13,8 & 862 & 119 & 27,0 & 3,7 & 2217 & 306 \\
\hline 18 & 12,7 & 1110 & 141 & 23,0 & 2,9 & 2543 & 323 \\
\hline 19 & 16,0 & 1000 & 160 & 8,2 & 1,3 & 434 & 70 \\
\hline 20 & 16,0 & 1019 & 163 & 9,0 & 1,4 & 913 & 146 \\
\hline 21 & 9,0 & 1600 & 144 & 11,0 & 1,0 & 387 & 35 \\
\hline 22 & 9,0 & 1600 & 144 & 15,0 & 1,3 & 859 & 76 \\
\hline 23 & 11,6 & 1470 & 171 & 9,5 & 1,1 & 1379 & 160 \\
\hline 24 & 8,1 & - & - & 11,81 & 1,0 & 5.56 & 45 \\
\hline
\end{tabular}




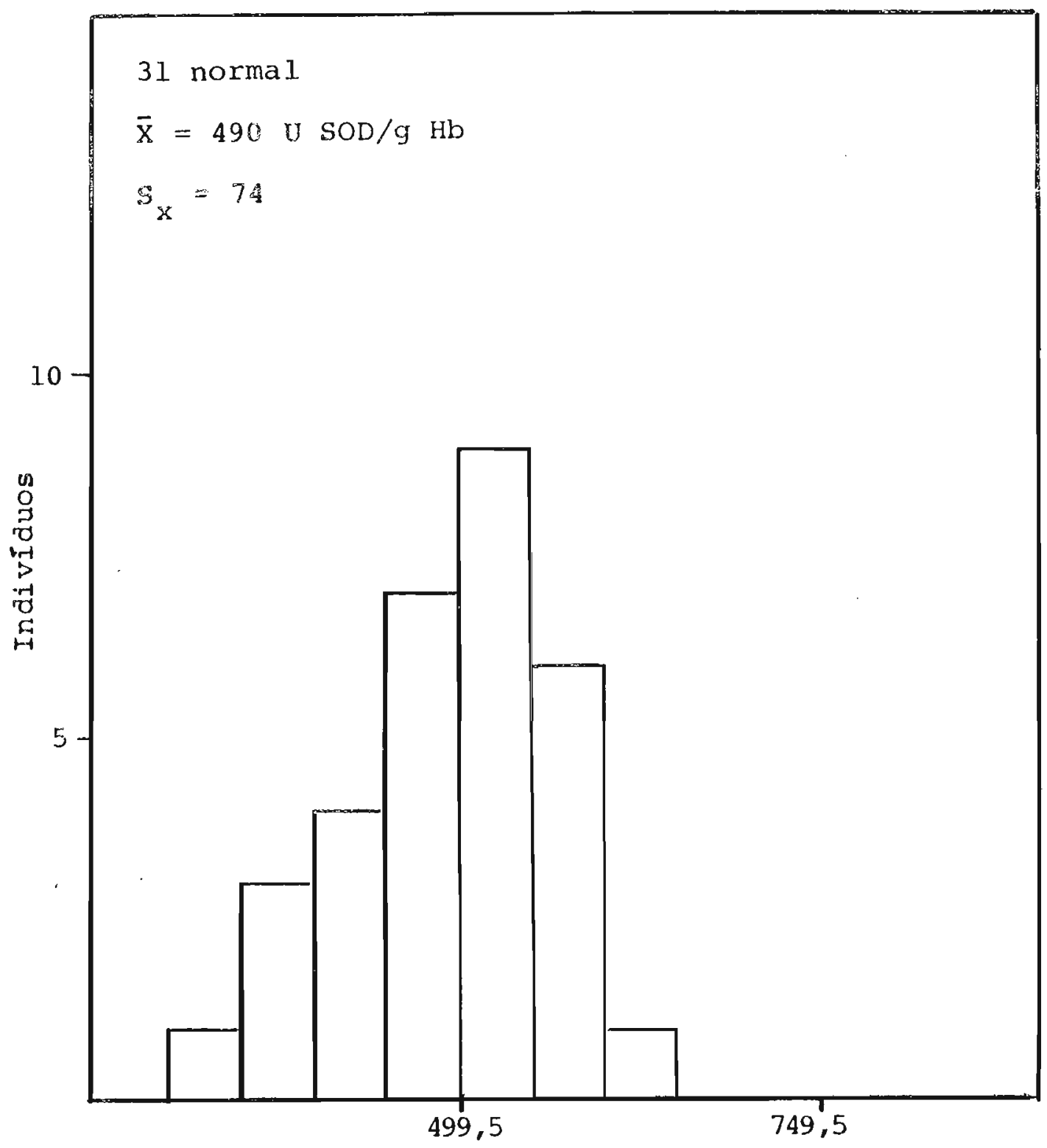

Unidades $\mathrm{SOD} / \mathrm{g} \mathrm{Hb}$

FICURA 4.1 - Distribuição dos valores em eritrócitos de indivíduos sadios. 


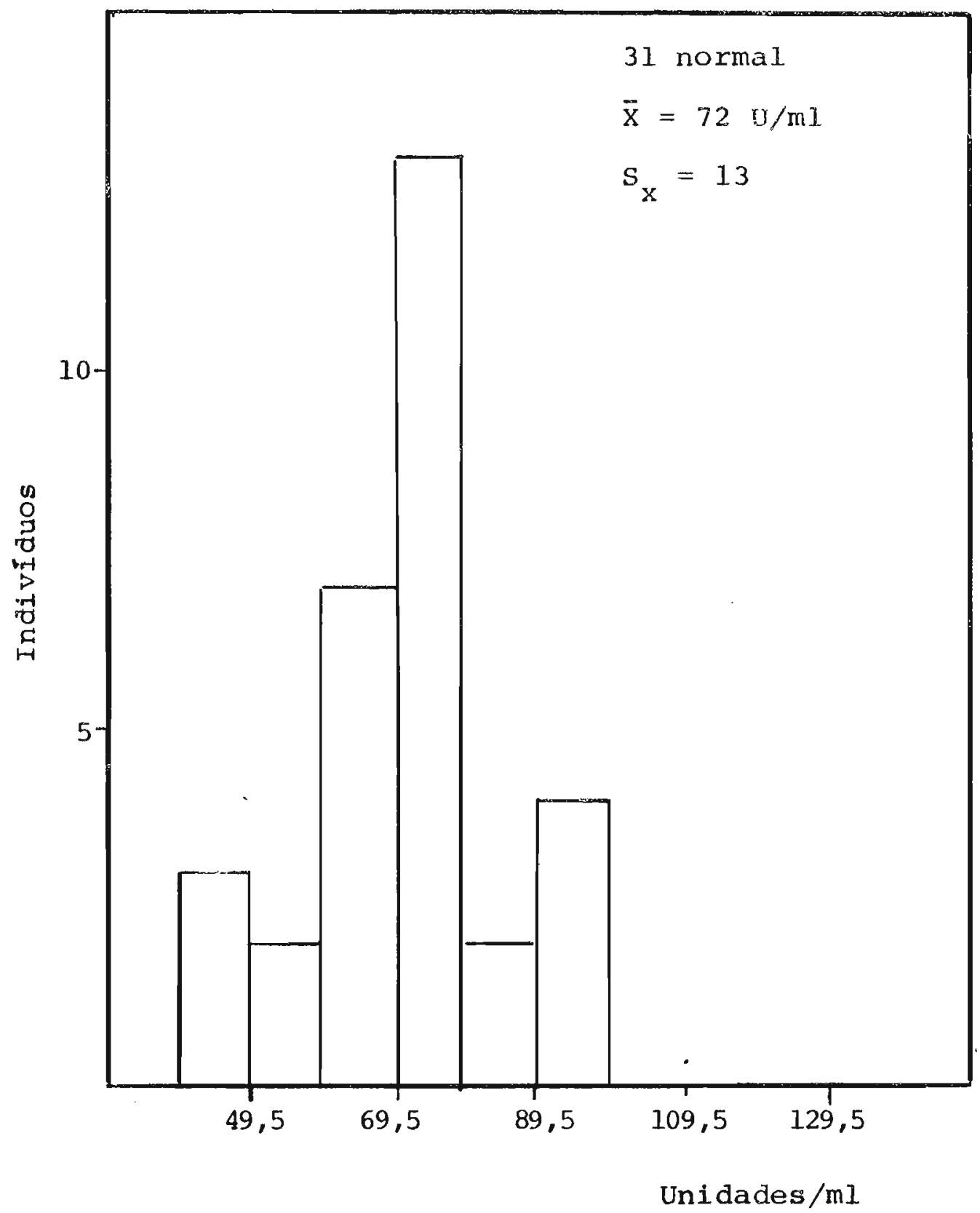

FIGURA 4.2 - Distribuição dos valores de SOD em eritrōcitos de indivíduos sadios. 
72.

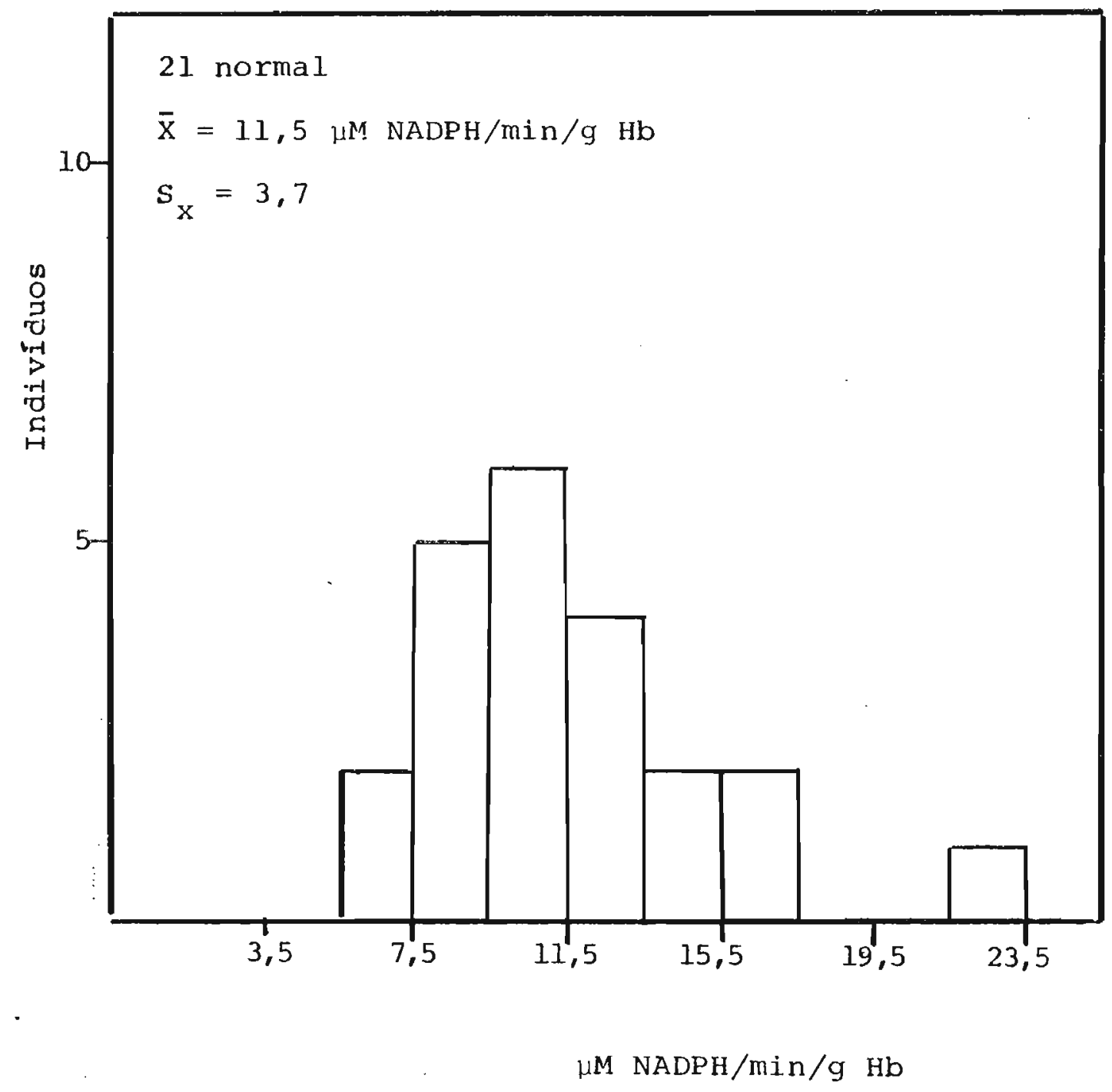

FIGURA 4.3 - Distribuição dos valores de GSH-PX em eritrócỉ tos de indivíauos sadios. 


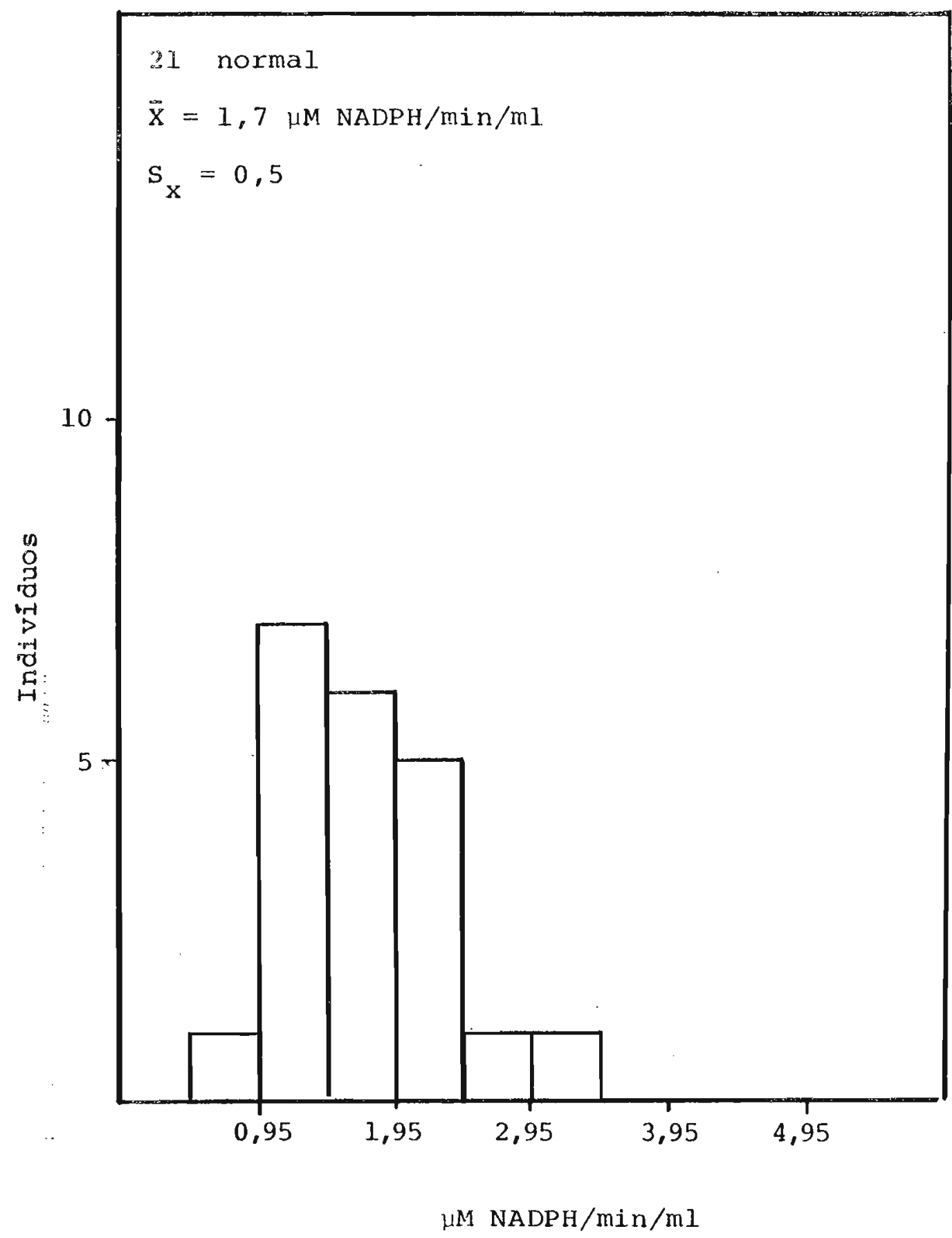

FIGURA 4.4 - Distribuição dos valores de GSH-Px em eritrócitos de individuos sadios. 


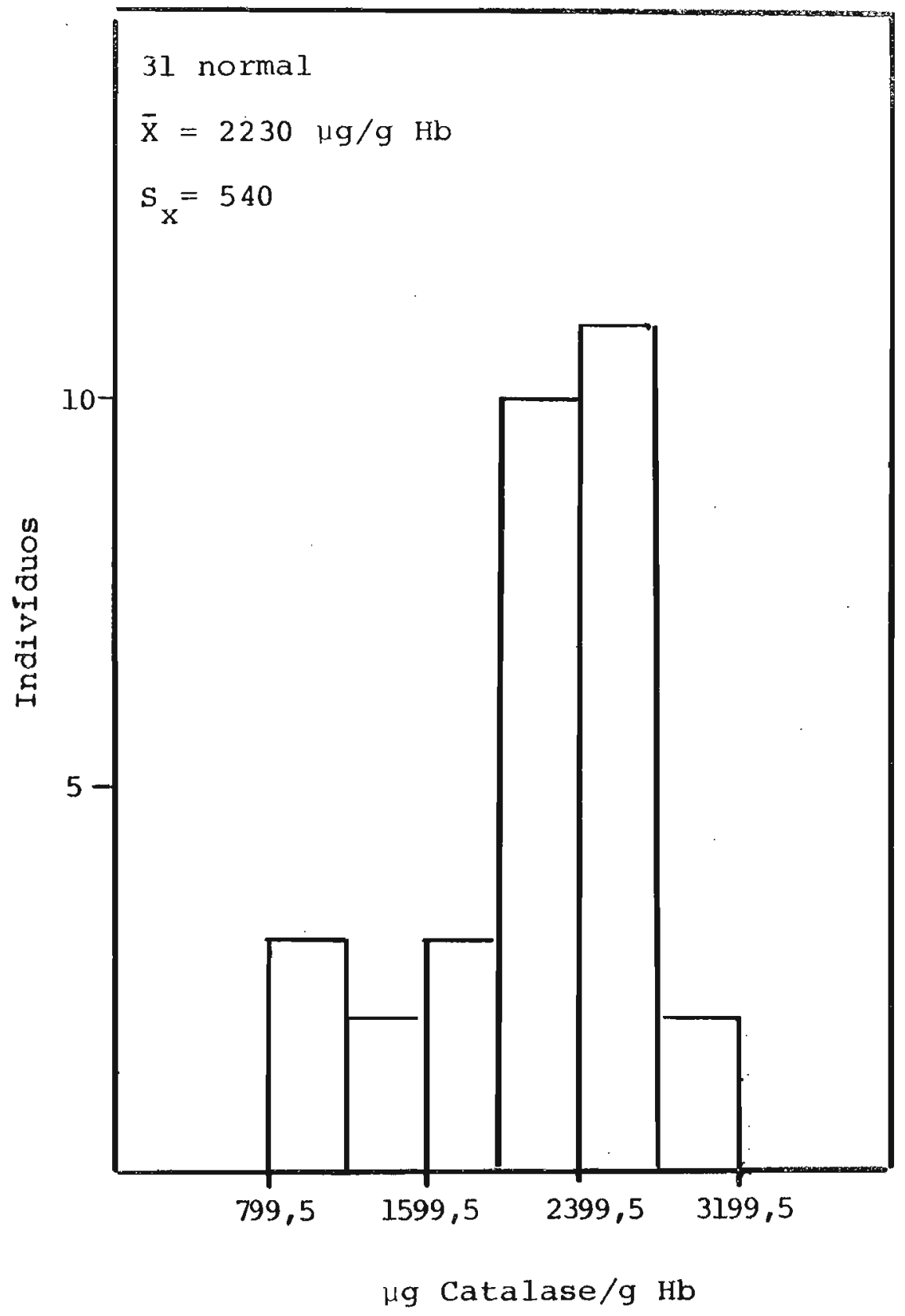

FIGURA 4.5 - Distribuição dos valores de catalase em eritrócitos de indivíduos sadios. 


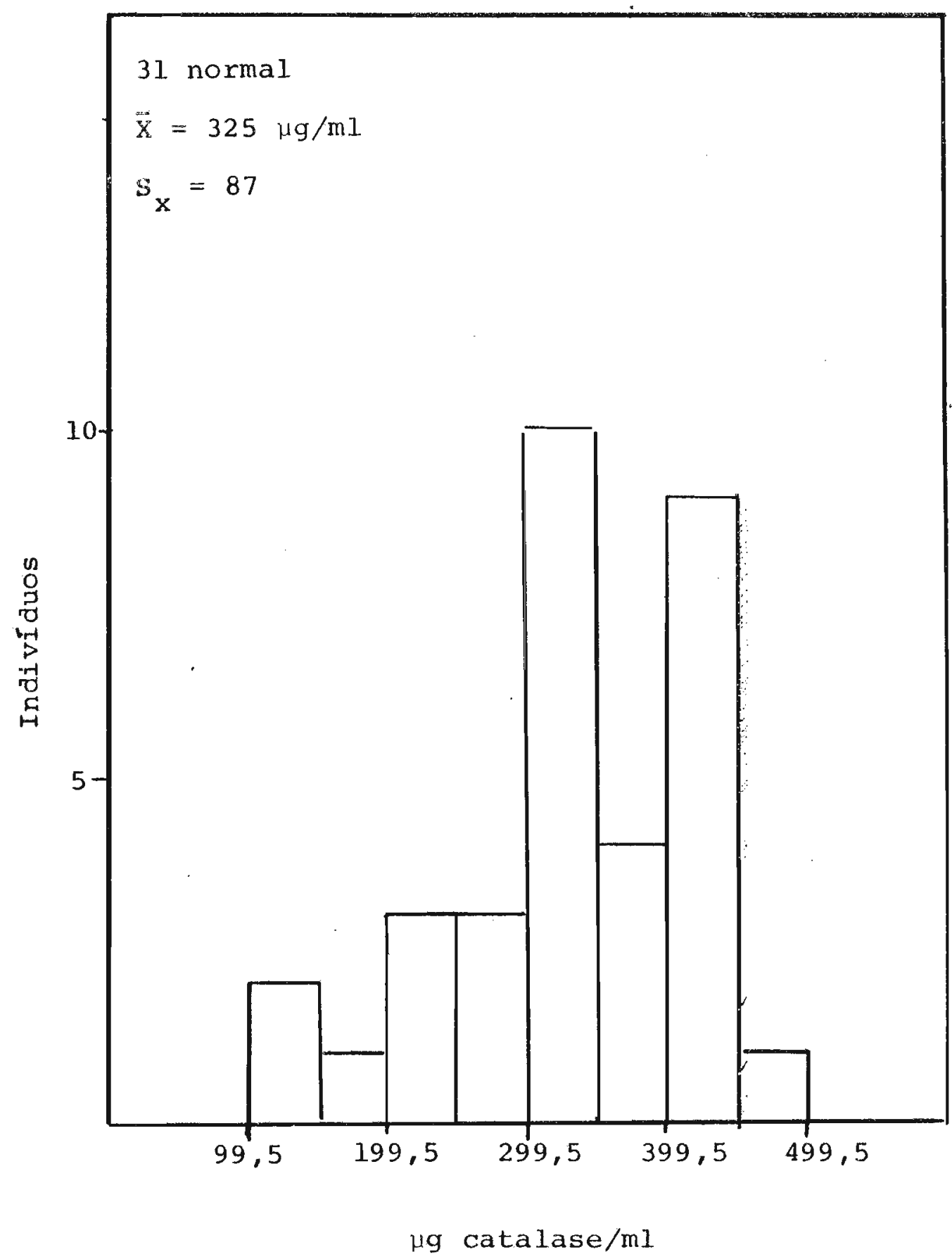

FIGURA 4.6 - Distribuição dos valores de catalase em eritröcitos de indivíduos sadios. 


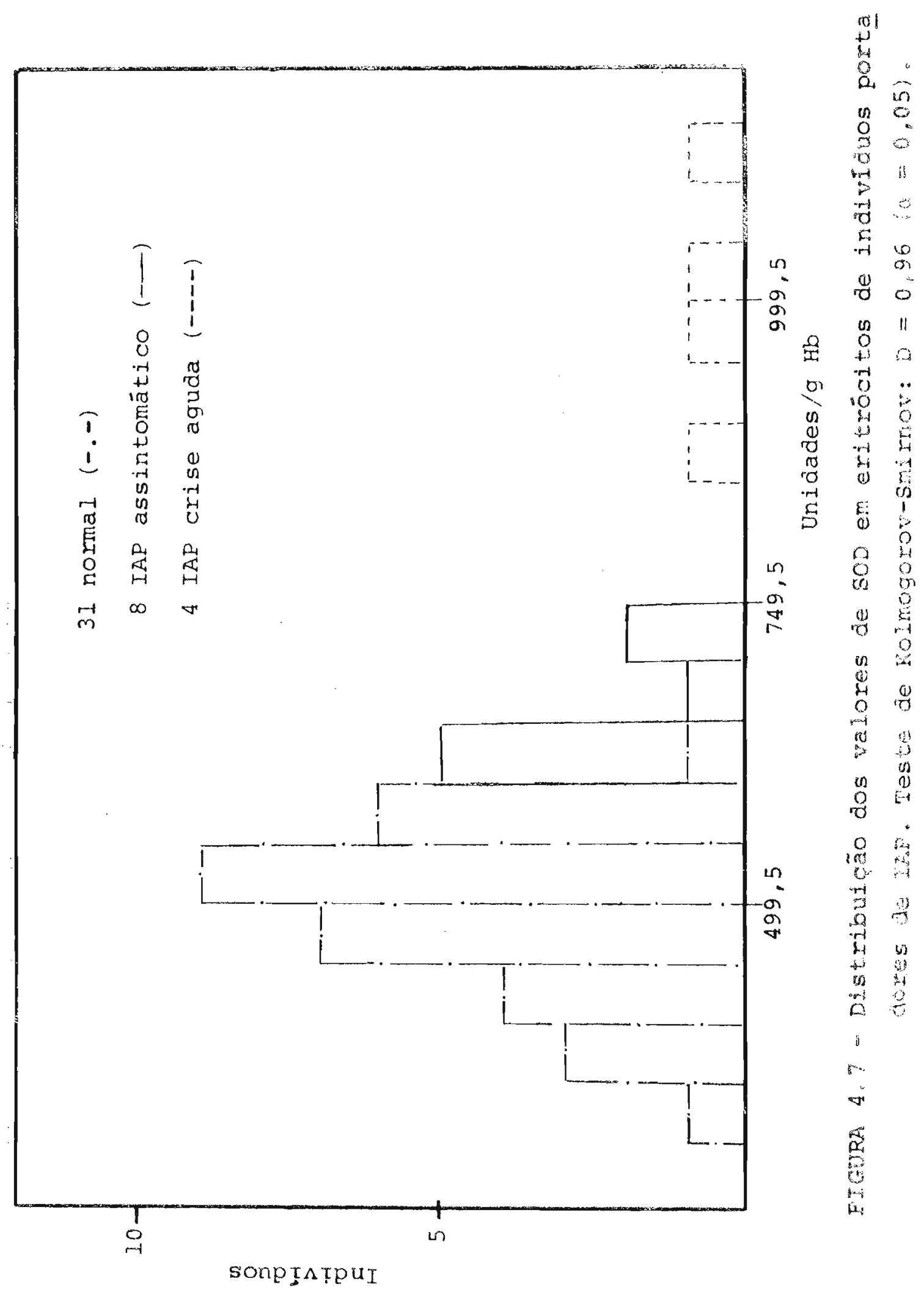




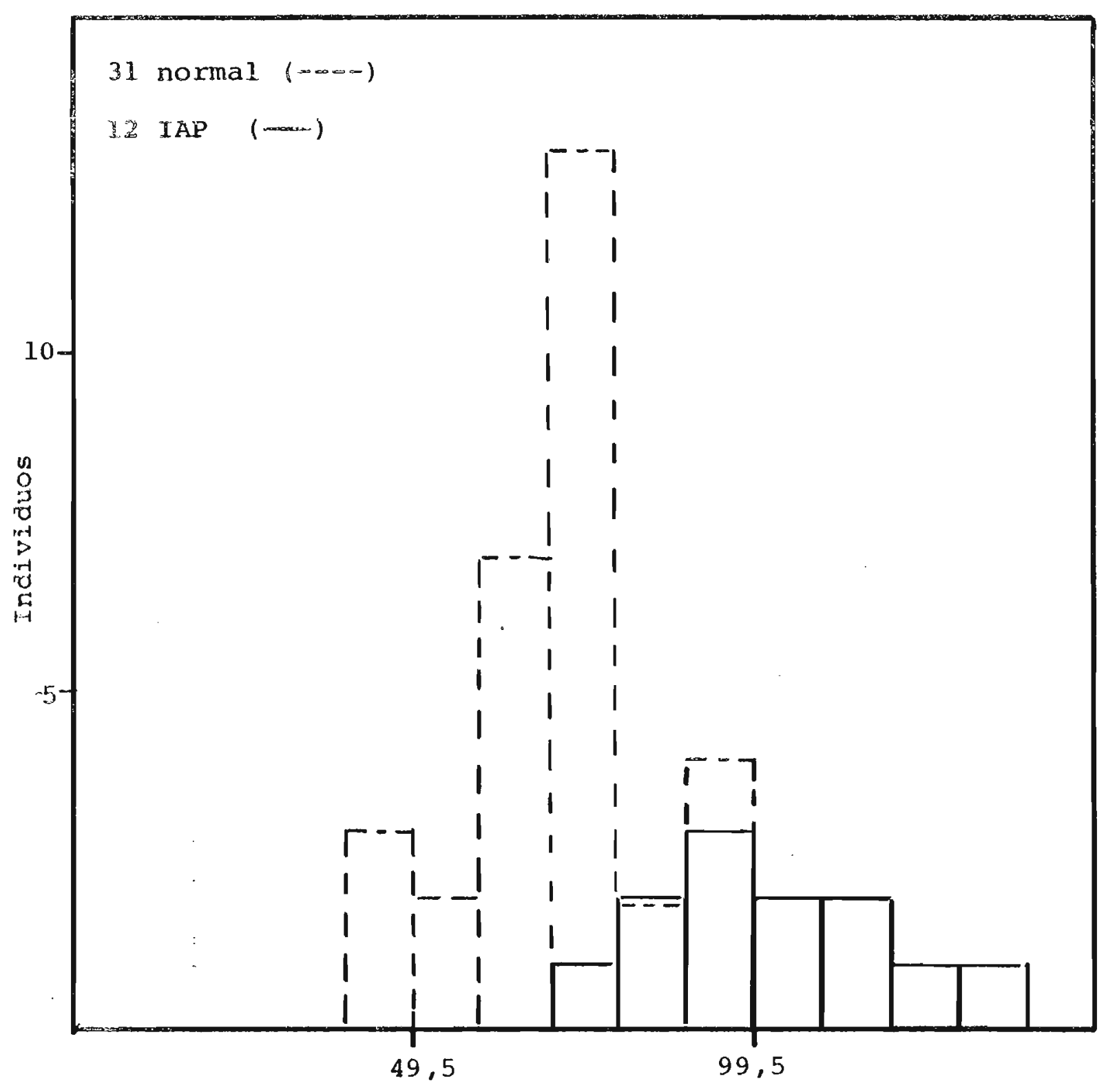

Unidades $\mathrm{SOD} / \mathrm{ml}$

FIGURA 4.8 - Distribuição dos valores de SOD em eritröcitos de individuos portadores de IAP. Teste de Kolmogorov--Smirnov: $D=0,64(\alpha=0,05)$. 


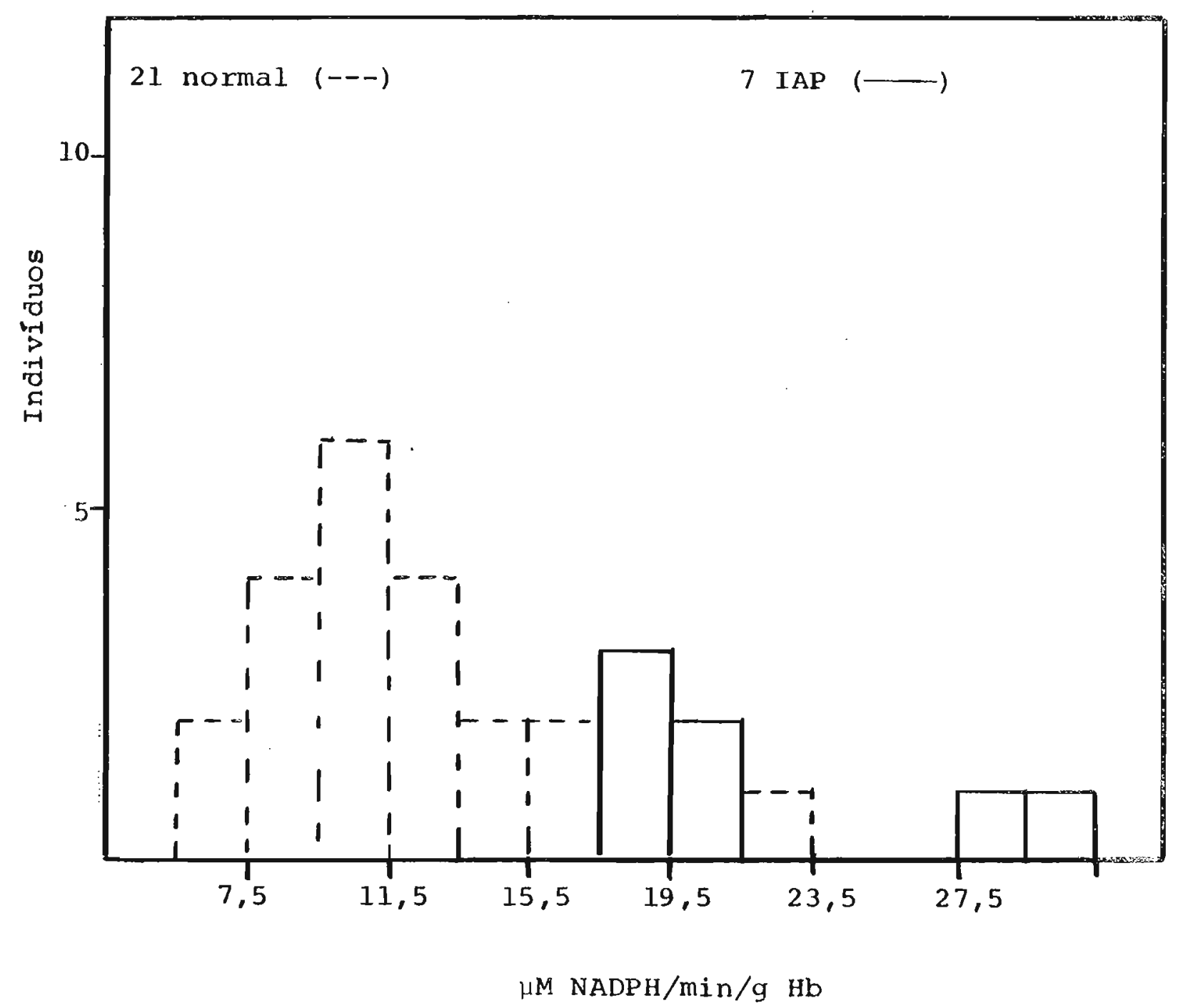

GURA 4.9 - Distribuição dos valores de GSH-Px em eritrócitos de indivíduos portadores de IAP. Teste de Kolmogorov-Smirnov: $D=0,88 \quad(\alpha=0,05)$. 


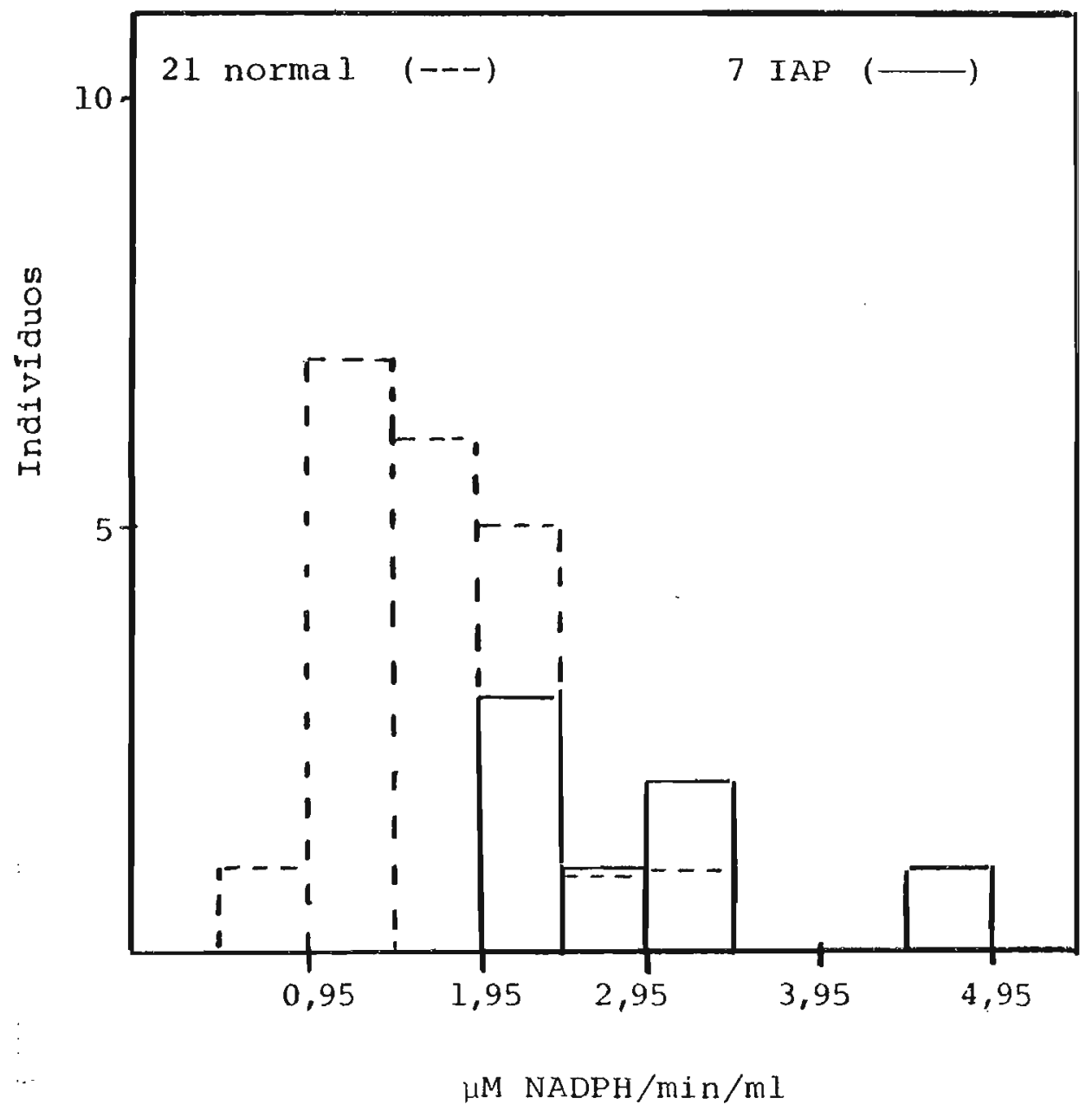

FIGURA 4.10 - Distribuição dos valores de GSH-Px em eritröcitos de indivíduos portadores de IAP. Teste de Kolmogorov-Smirnov: $D=0,81(\alpha=0,05)$. 


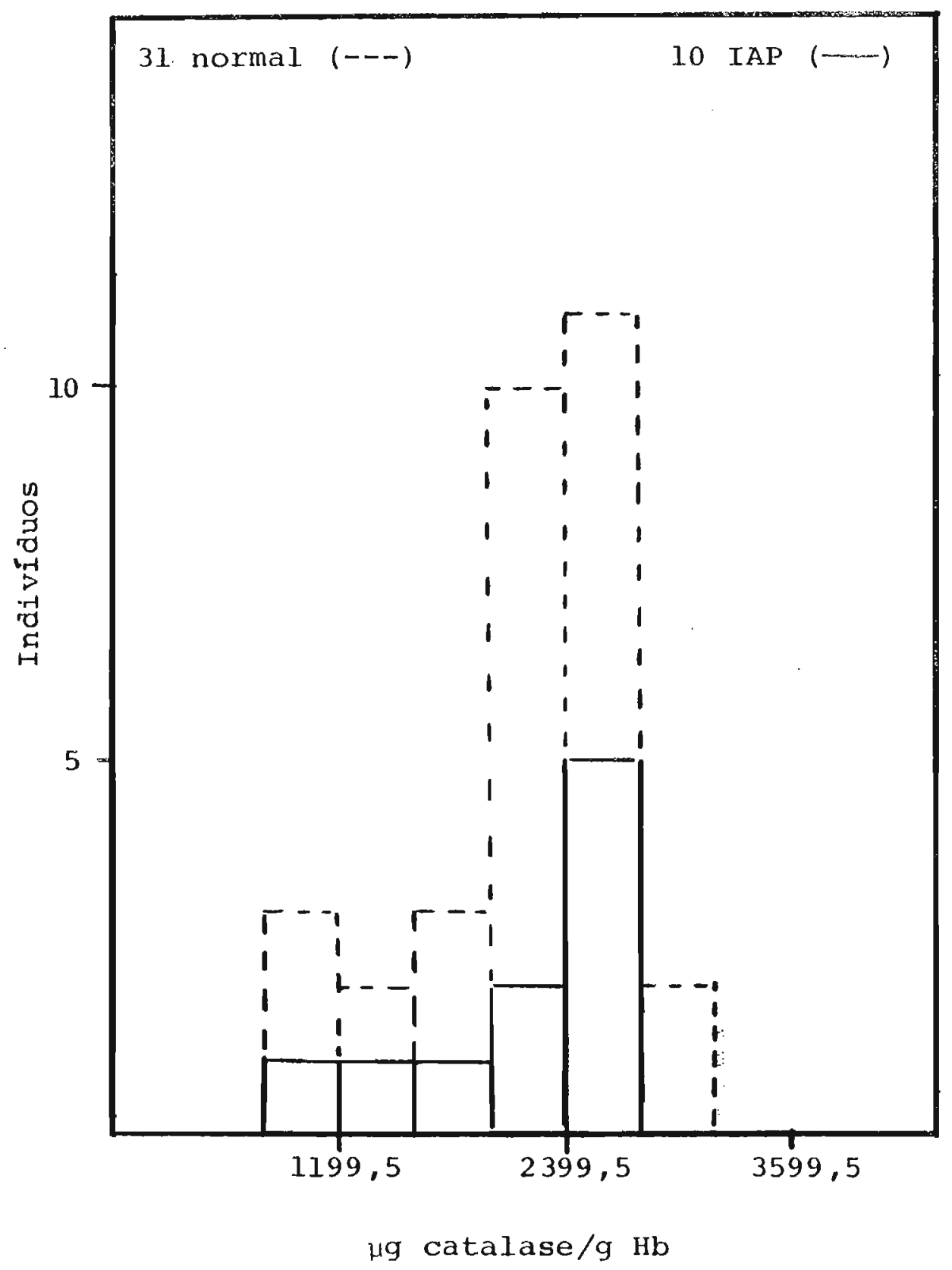

FIGURA 4.11 - Distribuição dos valores de catalase em eritröci tos de indivíduos portadores de IAP. Segunde teste de Kolmogorov-Smirnov as duas amostras perten- 


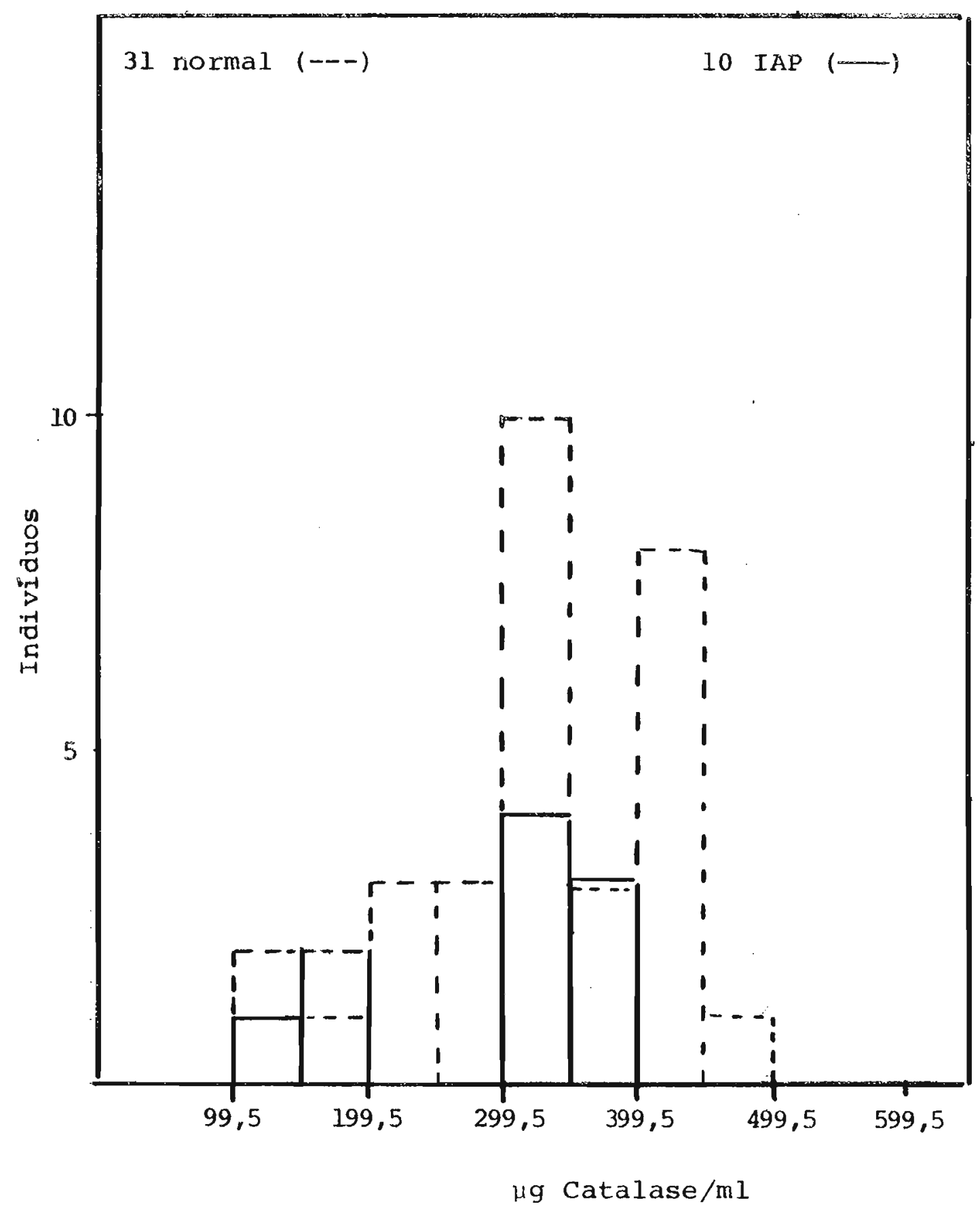

FIGURA 4.12 - Distribuição dos valores de catalase em eritrō citos de individuos portadores de IAP. Segundo teste de Kolmogorov-Smirnov as duas amostras per tencem a mesma população. 


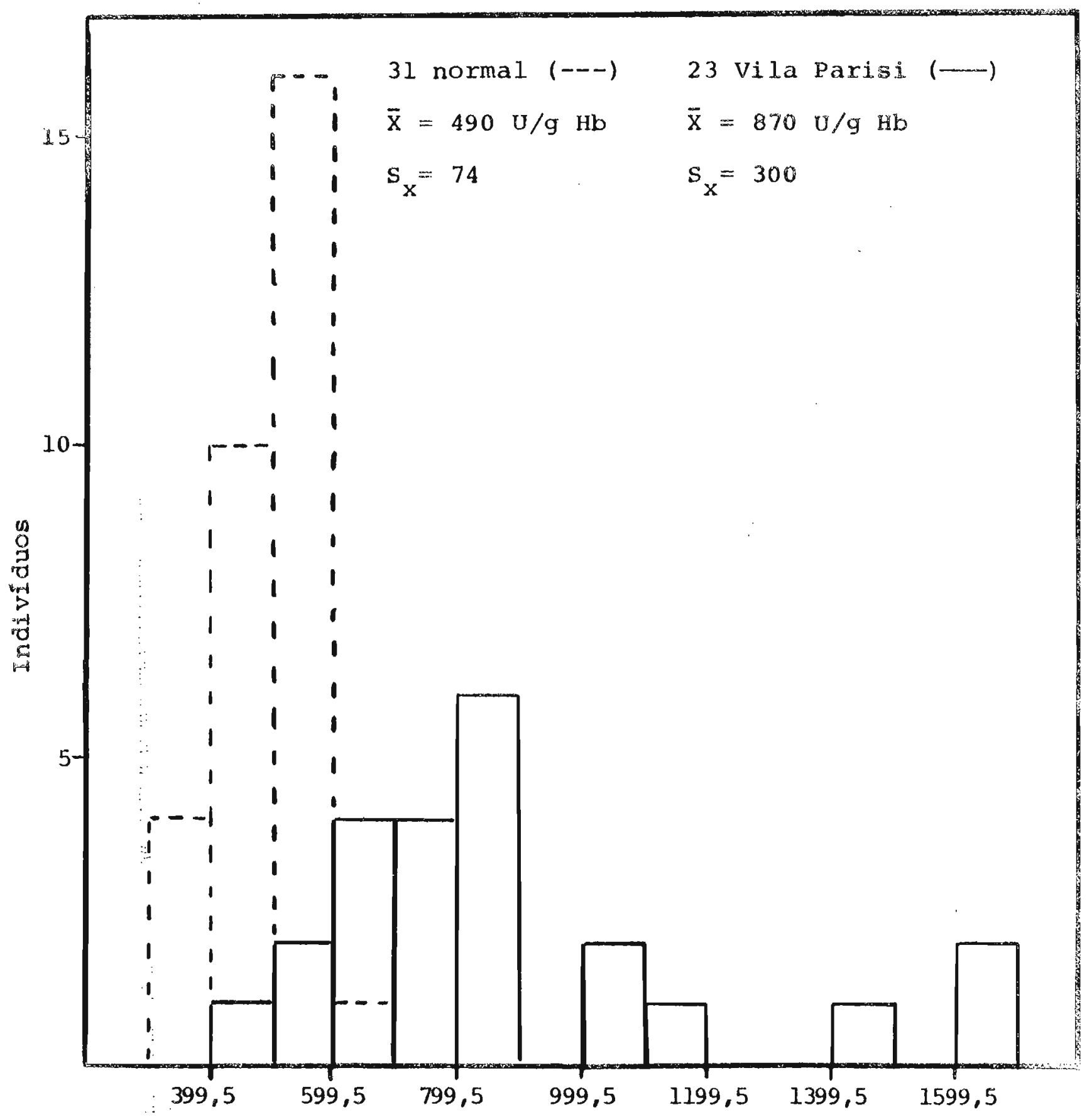

Unidades $\mathrm{SOD} / \mathrm{g} \mathrm{Hb}$

FIGURA 4.13 - Distribuição dos valores de SOD em eritrōcitos de individuos residentes em Vila Parisi. Teste de Kolmogorov-Smirnov: $\mathrm{D}=0,70(\alpha=0,05)$. 
83.

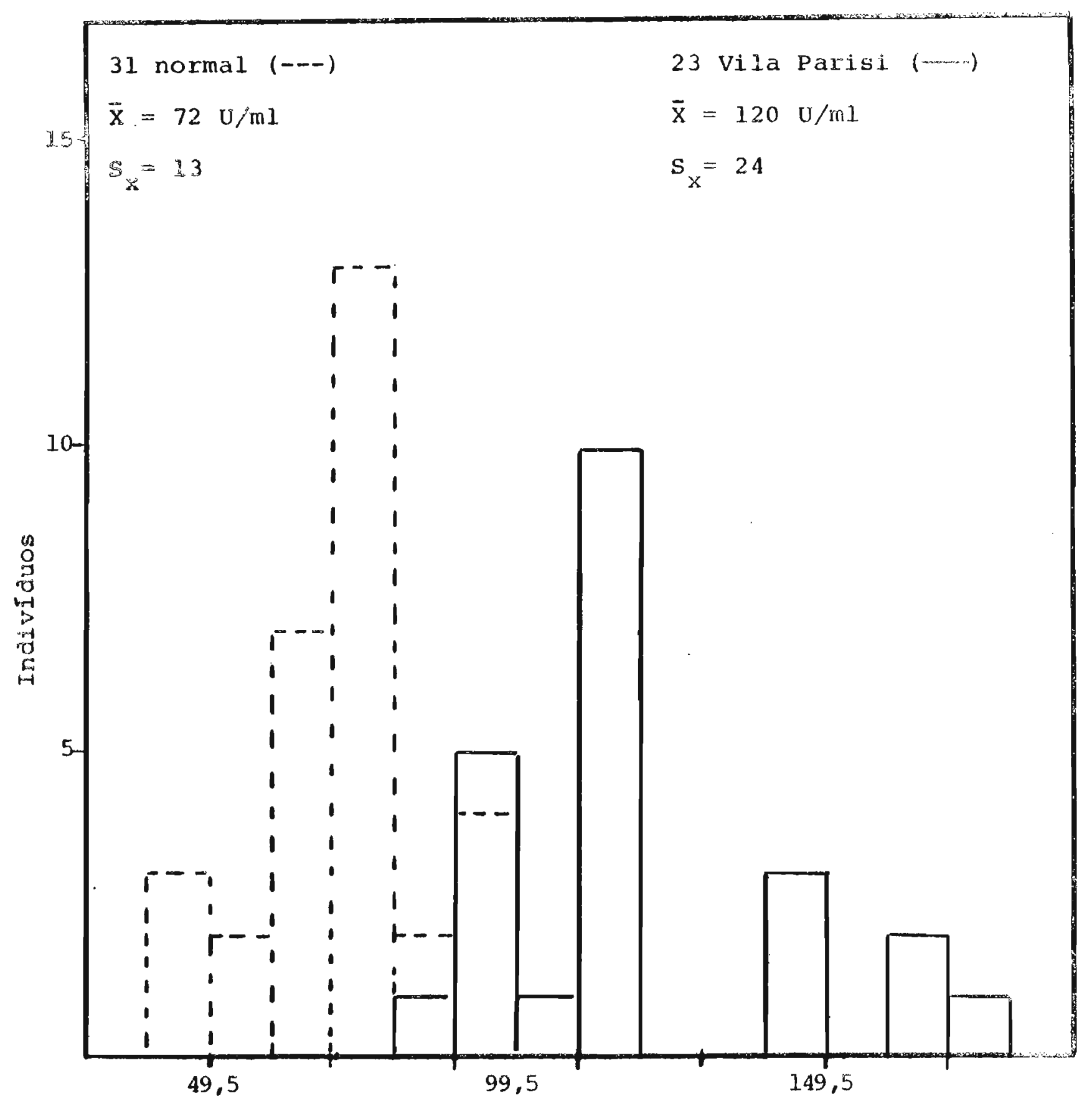

Unidades SOD $/ \mathrm{ml}$

FIGURA 4.14 - Distribuição dos valores de SOD em eritrócitos de residentes em Vila Parisi. Teste de Kolmogorov-

-Smirnov: $D=0,8 \quad(\alpha=0,05)$. 


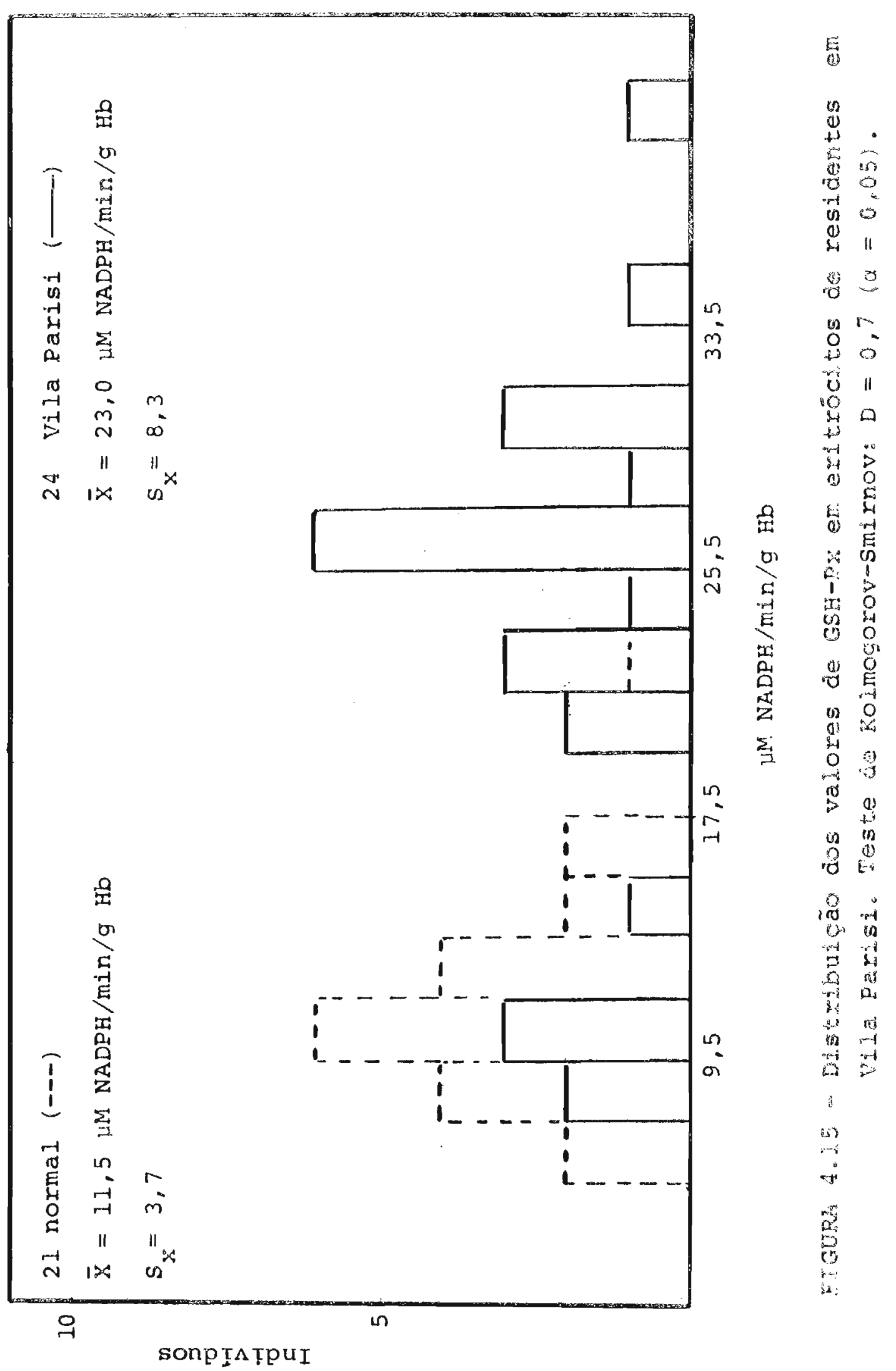




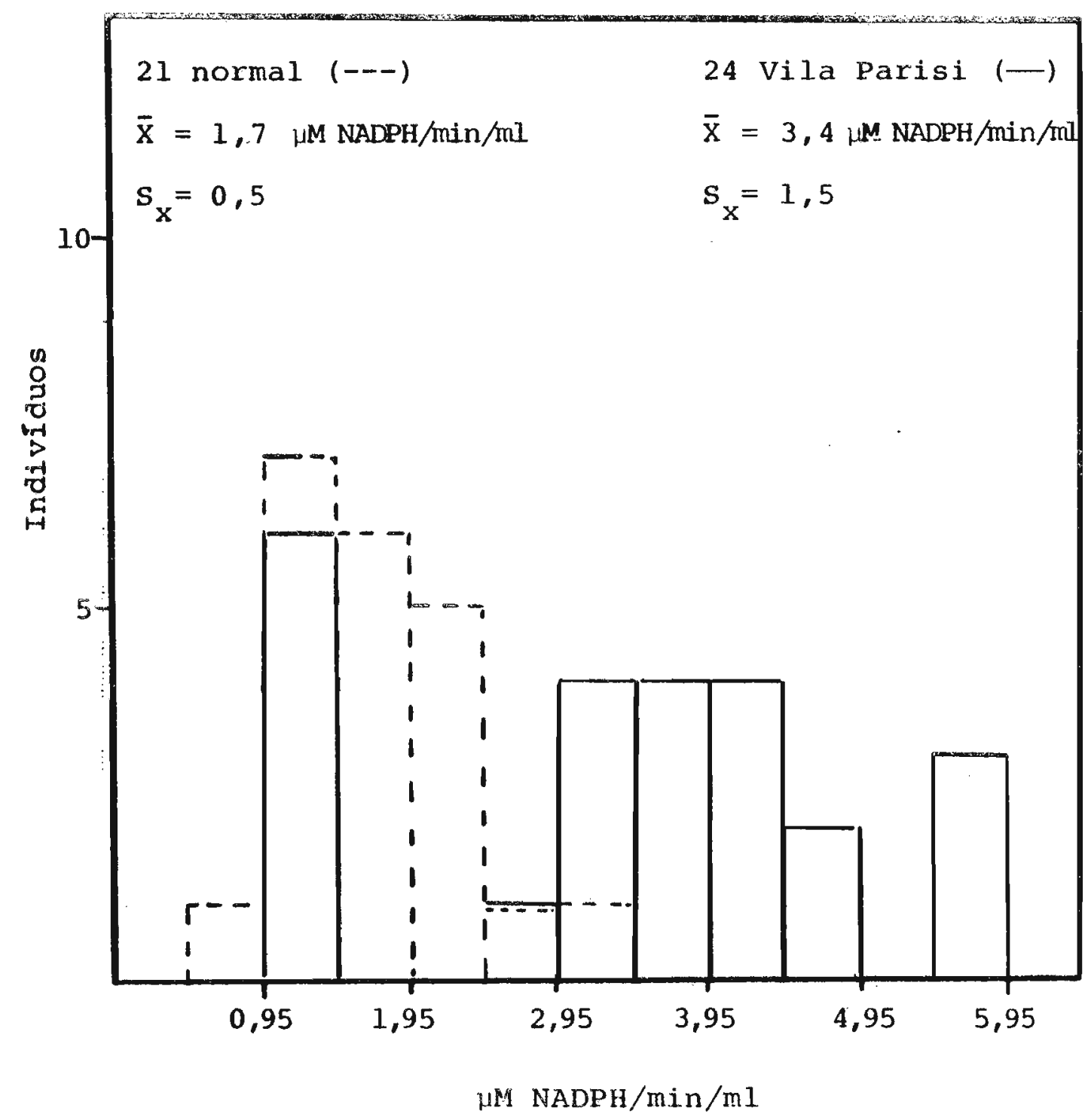

FIrURA 4.16 - Distribuição dos valores de GSH-Px em eritrö́ci-tos de indivíduos residentes em Vila Parisi. Teste de Kolmogorov-Smirnov: $D=0,55 \quad(\alpha=0,05)$ 。 
86.

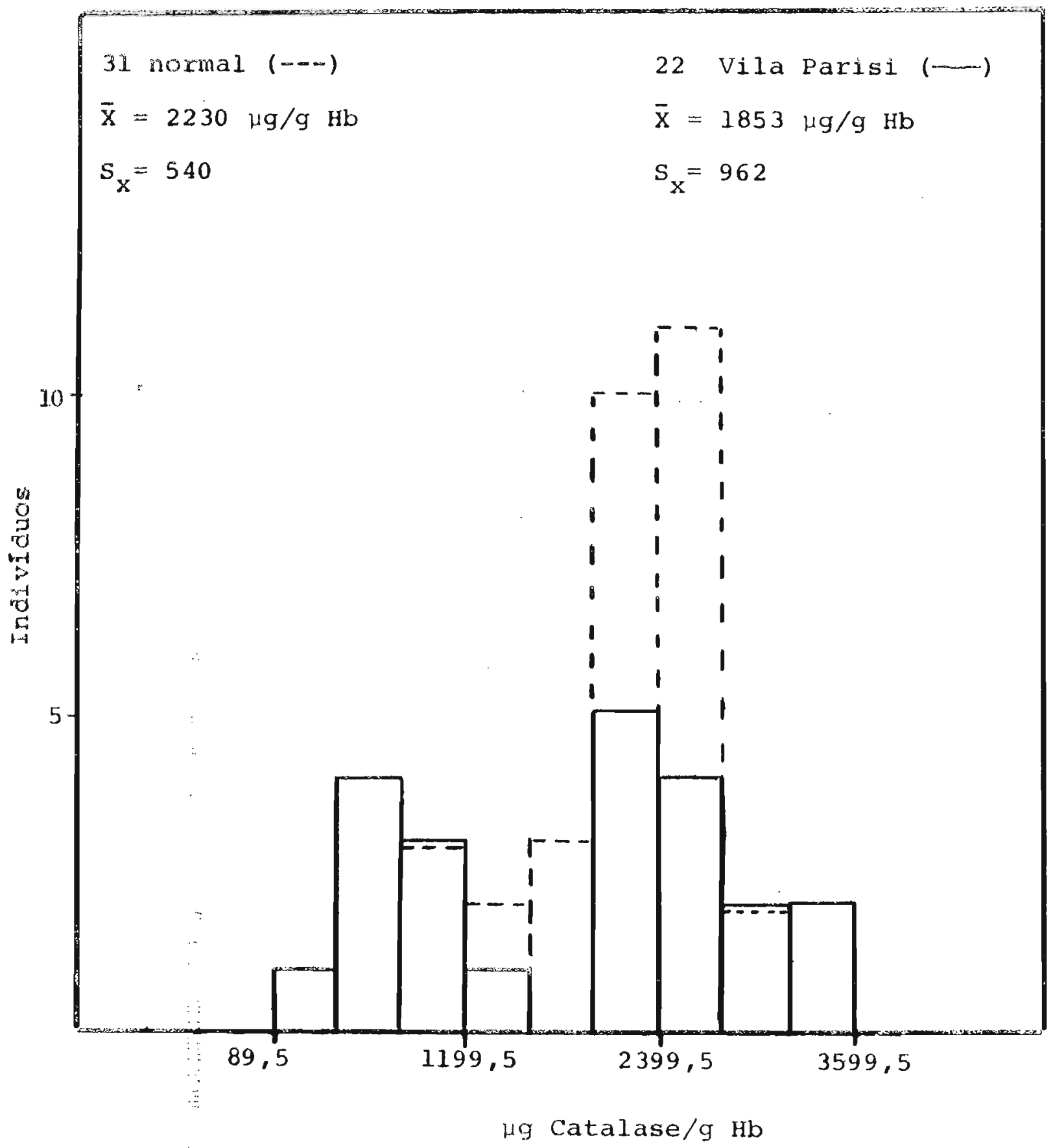

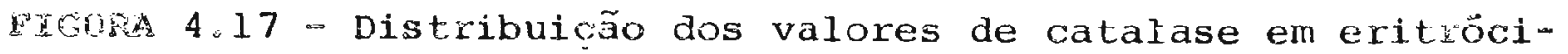
tos de indivíduos residentes em vila parisi. Segundo teste de Kolmogorov-Sminnov as duas amos- 
87.

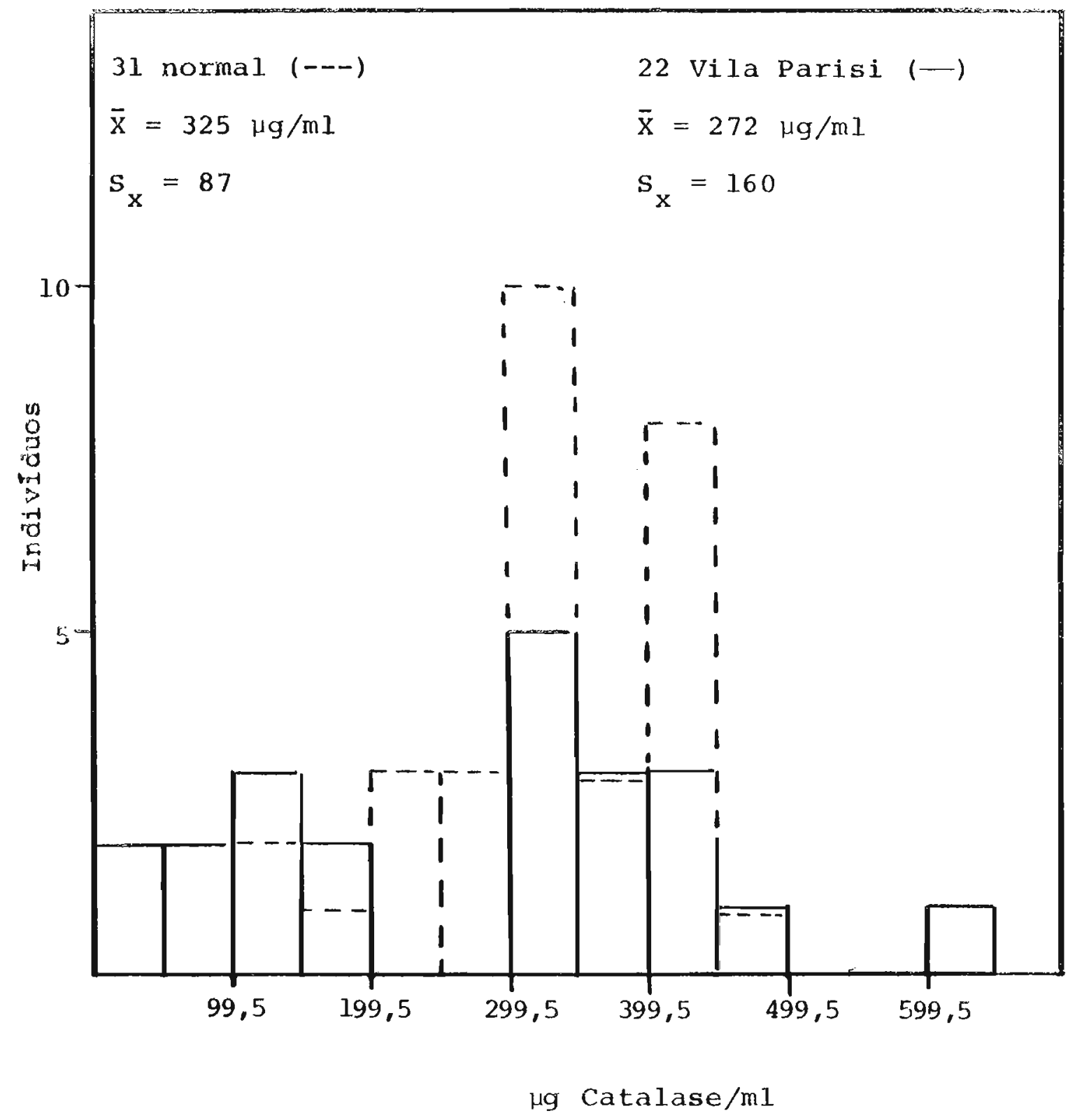

FIGURA 4.18 - Distribuição dos valores de catalase em eritrŏoi tos de individuos residentes em Vila Parisi. Segundo teste de Kolmogorov-Smirnov as duas amos-- 


\section{DISCUSSÃO E CONCLUSÕES}

\subsection{Metodologia}

Um exame cuidadoso da literatura quanto às concentrações eritrocitárias de $S O D$ de indivíduos normais revela enorme dispersão dos resultados obtidos por diversos autores (tabela 5.1).ES ta aparente inconsistência pode refletir sérios problemas em re lação à metodologia utilizada, talvez de padronização,o que com prometeria a comparação de nossos resultados (490 unidades de SOD/g de hemoglobina) com aqueles relatados na literatura. Outrossim, não se pode excluir a possibilidade de que tais diferenças expressem uma variação real na atividade de SOD devido a condições ambientais particulares (pressão de oxigênio, poluição atmosfërica, etc.) ou também que a atividade dessa enzima varie com a etnia do grupo controle, uma vez qué japoneses, fran ceses e africanos apresentaram níveis de SOD tão diversos.

E, portanto, importante que se dedique maior atenção à padronização dos métodos disponíveis e se conclua sobre a exatidão deles dentro de limites confiāveis. Seria interessante, por exemplo, verificar se a atividade enzimática medida por determi nado método é a mesma no hemolisado e no eluado de filtração em gel do lisado. Enquanto isso, os dados da literatura sobre os níveis de SOD em eritrócitos de determinada amostragem devem ser analisados não como medidas absolutas mas sim em termos das diferenças relativas a um grupo controle. 
TABELA 5.1. - Concentraçäo eritrocitäria de SOD em Indivíduos Normais.

\begin{tabular}{|c|c|c|c|}
\hline REFERENCIA & CIDADE & $\begin{array}{l}\text { METODO } \\
\text { (fonte de } \mathrm{O}_{2}^{\bar{\sigma}} / \text { sistema } \\
\text { detector) }\end{array}$ & $\begin{array}{c}\mathrm{U} / \mathrm{g} \mathrm{Hb} \\
(\mu \mathrm{g} / \mathrm{g} \mathrm{Hb})\end{array}$ \\
\hline $\begin{array}{c}\text { Michelson } \\
\text { colaboradores } \\
(1977)\end{array}$ & Paris & Flavina/NBT & $\begin{aligned} 1225 & \pm 120 \\
(461,4 & \pm 45,7)\end{aligned}$ \\
\hline $\begin{array}{c}\text { Ueda e Ogata } \\
\qquad(1978)\end{array}$ & Okayama & $\begin{array}{l}\text { Xantina-xantina } \\
\text { oxidase/NBT }\end{array}$ & $15500 \pm 2900$ \\
\hline $\begin{array}{c}\text { Okahata } \\
\text { colaboradores } \\
\text { (1980) }\end{array}$ & Hiroshima & Flavina/cit c & $13700 \pm 1700$ \\
\hline $\begin{array}{l}\text { Gerli } \\
\text { colaboradores } \\
\text { (1980) }\end{array}$ & Milão & $-\ldots$ & $(700 \pm 146)$ \\
\hline $\begin{array}{c}\text { Del Villano e } \\
\text { colaboradores } \\
(19.80)\end{array}$ & Cleveland & Radioimun. & (815) \\
\hline
\end{tabular}


A falta de homogeneidade na apresentação dos resultados constitui outro problema, pois a diversificação na forma de ex pressar atividade de SOD (unidades de SOD/g hemoglobina, unidades de SOD/ml de sangue, $\mu \mathrm{g}$ SOD/ml de células empacotadas, etc.) diliculta a comparação direta dos dados, como tambëm uma anảilse das variaçóes existentes nos diferentes grupos populacionais.

5.2. Níveis de SOD, Catalase e GSH-Px em Eritrócitos de Indivíduos Portadores de IAP.

Como comentamos na Introdução, a relação entre as anormali dades enzimāticas na biossintese do grupo heme nos casos de IAP e as manifestações neuropsiquiātricas da doença é ainda desconhecida (Meyer e Schmid, 1974). O envolvimento de heme e de hemina (no que diz respeito ao defeito genético e à terapia, respectivamente), as quais são fontes putativas de espécies ativadas, bem como o quaaro neuropsiquiātrico, foram o ponto de partida do presente trabalho. Nossa abordagem experimental, qual seja a de estudar metabolismo de oxigênio em portadores de IAP via dosagem das enzimas-chave em eritrócitos como cēlulas-mode1o, justifica-se pelo fato de a deficiência na biossintese de heme ter sido demonstrada em cēlulas hepāticas, nervosas, eritrōcitos e fibroblastos (Meyer e Schmid, 1974).

A dosagem de SOD eritrocitária em portadores de IAP mostrou um aumento de cerca de duas vezes nos níveis desta enzima em pacientes durante crise aguda e de cerca de 1,5 vezes nos portadores assintomáticos de IAP (Fig. 4.7 e 4.8). A aplicação do teste estatistico de Kolmogorov-Smirnov comprova que os ni- 
veis de SOD no grupo controle e em indivíduos portadores de IAP são distintos com um nível de significância de 0.05 .

Estes resultados podem ser interpretados seguindo duas linhas diferentes:

Uma primeira possibilidade é de que, devido aos altos nîveis de SOD no eritrócito destes pacientes, o par $\mathrm{O}_{2}^{\bar{j}} / \mathrm{HO}_{2}$ ocorreria em baixas concentrações. Lembramos aqui que espécies at vas de oxigênio desempenham papel importante em processos bioló gicos tais como:

(i) Os leucócitos, durante a fagocitose, apresentam um au mento repentino no consumo de $\mathrm{O}_{2}$. Está claro atualmente que $\mathrm{O}_{2}^{\bar{*}}$ e $\mathrm{H}_{2} \mathrm{O}_{2}$ são produzidos durante esse processo, sendo responsäveís pela ação antimicrobiana dessas células especializadas (Ross e Weening, 1979).

(ii) A degradação oxidativa de certos alucinōgenos como a triptamina ocorre provavelmente via $o_{2}$. De fato, essa espécie parece participar do mecanismo de reação da enzima que catalisa a clivagem oxidativa de indolaminas substituídas ou não como triptofano, 5-hidroxitriptofano, triptamina e serotonina (Hirata e Hayaishi, 1977).

(iii) A formação do neuromediador noradrenalina a partir de dopamina é catalisada pela dopamina B-hidroxilase, que é uma mo noxigenase que contém cobre e requer ascorbato para uma ativida de mäxima:

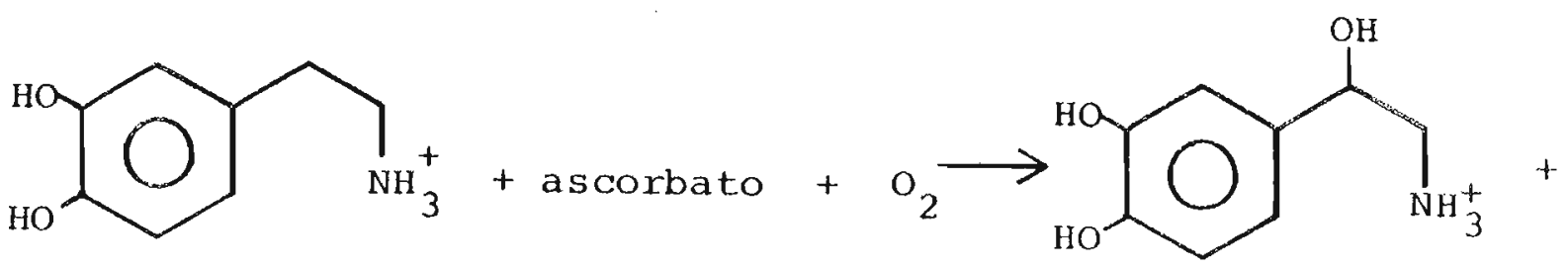


Iiu e colaboradores (1974) mostraram que a hidroxilação catalisada por essa enzima é diminuida com a adição de soD, sugerindo um possível envolvimento de $\mathrm{o}_{2}^{\bar{j}}$ no seu mecanismo de ação. Entre tanto, como esses resultados estão sendo contestados por aiversos autores (Diliberto e Kaufman, 1977), tal mecanismo precisa ser confirmado.

Levando em conta os dois últimos itens, poder-se-ia sugerir que nos casos de IAP uma diminuição da concentração intrace lular de $\mathrm{O}_{2}^{\overline{1}}$ levasse ao bloqueio destes processos, comprometendo assim a neurotransmissão e a destruição oxidativa de halucinógenos. Este tipo de argumento foi usado por Michelson e colab. (1977) para explicar vārios casos dẹ aberrações mentais em algumas doenças hereditárias e outras adquiridas.

Uma segunda possibilidade seria a interoretação com base na indução de SOD. Como oxigênio é um conhecido indutor desta enzima (Crapo e Tierney, 1974), os níveis elevados de SOD em portadores de IAP podem advir como resposta metabólica a concen trações excessivas de espécies ativadas de oxigênio. Tais espēcies, são extremamente tóxicas podendo levar a:

(a) aumento na oxidação de vários neuromediadores como a epinefrina (Misra e Fridovich, 1972), causando por exemplo, aber raçöes mentais;

(b) diversos trabalhos, mostraram que a adição de SOD ao meio de suspensão protege E.coli B (Gregory e Fridovich, 1973)。 E. coli K.12 (Hassan e Fridovich, 1977), Saccharomyces aerevisiae (Gregory e colaboradores, 1974) e pulmão de rato (Crapo e Tierney, 1974) contra os efeitos tóxicos de oxigênio. Portanto, a 
proteção desta enzima extracelularmente sugere que as membianas săo possîveis alvos de espëcies ativas de $\mathrm{O}_{2}$. Assim divexos problemas hepăticos poderiam surgir como consequência de danos nas membranas das células e de partículas subcelulares como mitocondxias de Eígado.

Nossos estudos com indivíduos portadores do defeito IAP re velaram um aumento de cerca de duas vezes nos niviveis eritrocitá rios de GSH-PX em relação ao controle, resultado este tambēm confirmado por tratamento estatístico não paramétrico de (Kolmo gorov-Smirnov (Fig. 4.9 e 4.10). Observou-se para o grupo controle (Fig. 4.3 e 4.4) uma atividade de GSH-Px ém torno de 11,5 $\mu \mathrm{M} \mathrm{NADPH} / \mathrm{min} / \mathrm{g} \mathrm{Hb}$ a $37^{\circ} \mathrm{C}$. Maral e colaboradores (1977) encontraram pá ra indivíduos normais uma atividade média de 5,73 $\mu \mathrm{M} \mathrm{NADPH} / \mathrm{min} /$ $9 \mathrm{Hb}$, medida a $25^{\circ} \mathrm{C}$.

A enzima GSH-Px tem sido apontada como responsável por pro cessos biológicos importantes, tais como:

(a) Proteção de lipídeos insaturados em membranas. Este pạ pel da GSH-Px tem sido discutido por diversos autores, com base em evidēncias como: capacidade desta enzima de catalisar a redu ção de hidroperóxidos de äcidos graxos (Little e O'Brien, 1968); prevenção, pela GSH-Px, da degradação oxidativa de fosfolipídeos e concomitante formação de malonaldeído em membranas internas de fígado de rato (Flohé e Zimmermann, 1974) e acúmulo de produ tos de degradação de lipỉdeos insaturados, in vivo, através de inibição de GSH-Px (Omaye e colaboradores, 1975). Ressaltamos aqui, que condições onde uma alta taxa de remoção de peróxí dos lipídicos é necessāria, como a exposição a ozone (Chow e 
Tappel, 1972) ou a ingestão de peróxidos lipídicos (Reddy e Tappel, 1974), levam a um aumento na atividade desta enzima.

(b) Mutagênese- Os peróxidos são considerados como mutagènicos e a GSH $\sim \mathrm{Px}$ reagindo com hidroperóxidos de ácidos nucleícos e seus precursores (Cristophersen, 1969), teria um papel no bloqueio de tais processos. Tal hipótese é reforçada pela obser vação de relações entre o suprimento de selēnio, elemento essencial à atividade catalítica de GSH-Px, e a incidência de cân cer. Suplementação de doses subtóxicas de selēnio diminuem a in cidência de tumores em diversos modelos de carcinogênese química, bem como em alguns tumores mamārios em camundongos (Jacobs e colaboradores, 1977). Por outro lado, alguns estudos epidemio lógicos têm revelado uma relação inversa entre dieta com selênio e mortalidade por câncer (Schrauzer e colaboradores, 1977). Portanto, é necessário aprofundar esses estudos com o intuito de se esclarecer a vinculação entre a teoria fundamentada na re moção de hidroperóxidos mutagênicos e os resultados empíricos derivados dos estudos epidemiológicos.

(c) Biossintese de prostaglandinas- Ainda não está claramente estabelecido o envolvimento de GSH-Px na biossintese de prostaglandinas. Entretanto, recentes estudos neste campo levaram à descoberta de diversos peróxidos, intermediärios na reação em cascata do àcido araquidônico. A figura 5.1 mostra um esquema da biossintese de prostaglandinas, indicando os possíveis sítios onde GSH-Px intervem. Uma vez que as fontes de prostaglandinas - o ácido araquidônico e outros ácidos graxos polinsa turados - devem ser protegidas contra degradações cxidativas inespecíficas, a ação de GSH-Px provavelmente garante a operacio 


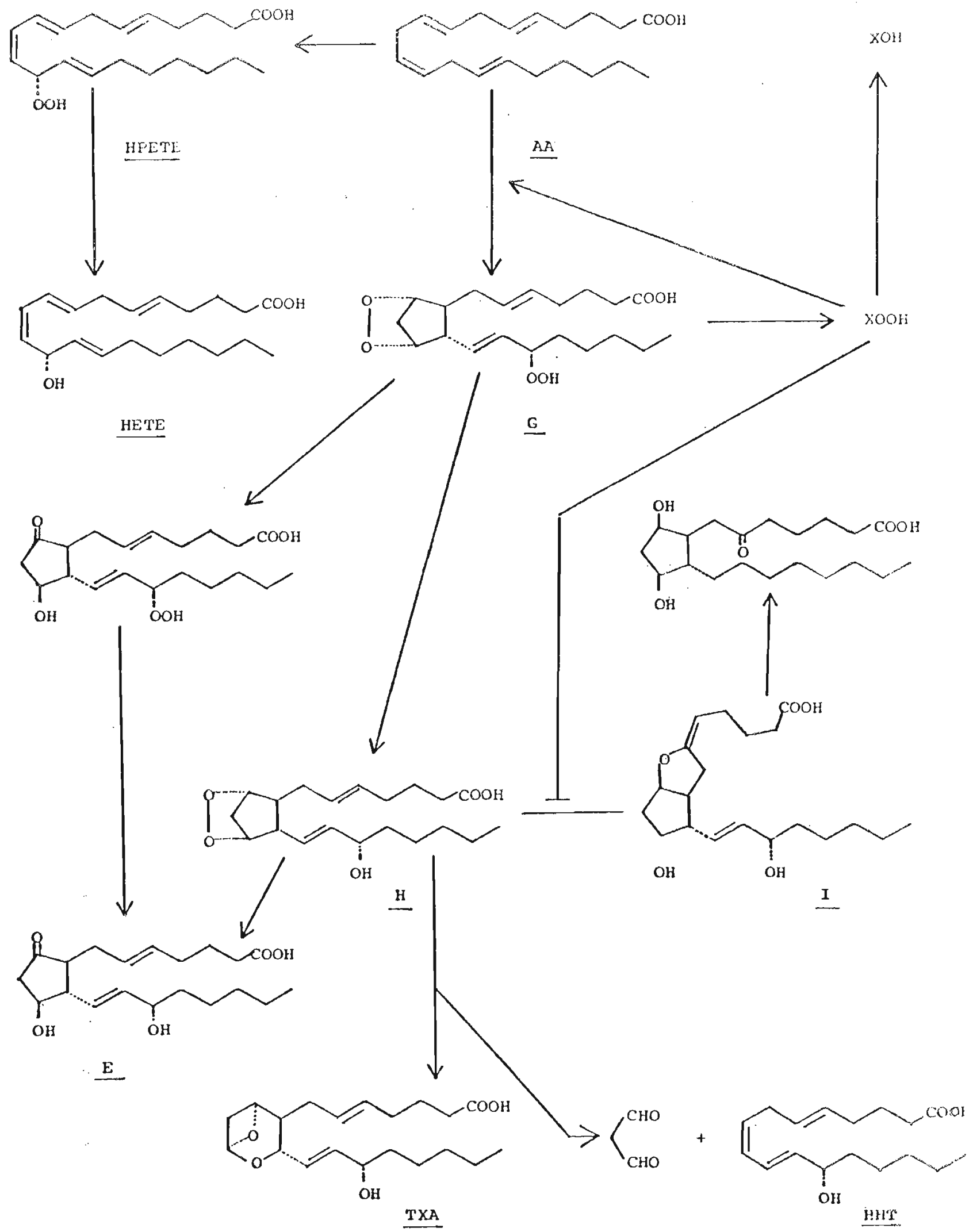

FIGURA 5.1 - Possíveis sítios de interação de GSH-PX com a reação em cascata do ácido araquidōnico (AA) : HPETE, ācido 12-hidroperoxieicosatetraenóico; HETE, ácido 12-hidroxieicosatetraenóico; G, prostaglandina $\mathrm{G}_{2} ; \mathrm{E}$, prostaglandina $\mathrm{E}_{2} ; \mathrm{I}$, prostaciclina; TXA, tromboxano $\mathrm{A}_{2} ; \mathrm{H}$, prostaglandina $\mathrm{H}_{2}$. 
nalidade desses substratos indispensäveis.

E tambẻm digna de nota a descoberta por Gryglewski e colaboradores (1976) de que a formação de prostaciclina é inibïda por hidroperóxidas de ācidos graxos. A GSH-Px poderia então man ter a concentração desses hidroperöxidos suficientemerte baixa para garantir a formação dessa espécie. Uma vez que a prostaciclina do endolélio arterial antagoniza a adesão de plaquetas e a agregação induzida por tromboxano $A_{2}$ (TXA na fig. 5.1), uma deficiência em GSH-Px nas células endoteliais favoreceria um au mento patológico na adesão das plaquetas levando ao desenvolvimento de ateromatoses (Flohé, 1979). Esses dados são reforçados por estudos epidemiológicos feitos nos Estados Unidos, os quais revelaram que a taxa de mortes por doenças cardiovasculares cor relaciona-se inversamente com o suprimento de selênio (Schamber ger, 1976).

Em conclusão, a GSH-Px certamente estä envolvida no contro le de diversos processos biológicos. Situações onde é necessaria uma alta taxa de remoção de peróxidos lipídicos levam a um aumento nos níveis de GSH-Px. Pode-se sugerir, portanto,que nos casos de IAP estudados, a elevação de cerca de duas vezes no nível desta enzima reflete uma resposta metabólica a níveis celulares excessivos de hidroperóxidos. Este fato deve estar rela cionado com o aumento paralelo (também de duas vezes) na atividade de SOD dos mesmos pacientes, uma vez que a dismutação de $0_{2}^{\bar{j}}$ via soD gera peróxido de hidrogênio.

Não foram observadas diferenças entre os níveis de catalaw se de indivíduos normais e portadores de IAP. De certa maneira, 
estes resultados eram esperados, uma vez que a catalase provavelmente controla os niveis de $\mathrm{H}_{2} \mathrm{O}_{2}$ em apenas alguns compartimentos celulares como microsomas, nucleo e peroxisomas (Flohé e Schlege1, 1971), ficando a GSH-Px responsável pela remoção da $\mathrm{H}_{2} \mathrm{O}_{2}$ nos demais compartimentos onde a concentração de catalase é baixa. A GSH-Px exerce portanto um "controle fino" dos níveis de peróxidos nas células, cabendo à catalase entrar em ação em situações de emergência quando o nível de $\mathrm{H}_{2} \mathrm{O}_{2}$ sobe demasia damente.

A administração intravenosa de hemina $(4 \mathrm{mg} / \mathrm{kg}$ duas vezes ao dia) a dois pacientes sob crise aguda não alterou a atividade das três enzimas, dosadas dois dias consecutivos antes e très dias consecutivos apōs o tratamento. Contudo, nestes casos, a hemina tambëm se mostrou ineficiente na redução dos sintomas neuropsíquicos. De fato, ainda existe muita controvérsia sobre - uso desta droga e de carbohidratos no tratamento de IAP (Moore e colaboradores, 1980).

Segundo Meyer e Schmid (1974), um dos possíveis mecanismos, que explicam a relação causa-efeito entre as anormalidades enzi māticas na biossintese do grupo heme e as manifestações neuropsiquiátricas em pacientes portadores de IAP, consiste no acúmu lo de ALA e/ou PBG no sistema nervoso, após slia formação no fígado e transporte para aquele sistema. A adição de ALA e PBG aos sistemas de dosagem das enzimas em estudo, entretanto, não provoca nenhuma alteração na atividade das mesmas, o que excluiria à primeira vista, um possível efeito destes precursores na atividade de SOD e GSH-PX. 
Tendo em vista os argumentos que acabamos de citar e dados publicados por Michelson e colaboradores (1977), onde diversas doenças mentais estão associadas com níveis alterados de SOD e GSH-PX (Tabela 5.2), pode-se sugerir o envolvimento de espécies ativas de oxigênic nas manifestações neuropsiquiätricas em IAP. Nossa proposta dä suporte a um dos mecanismos postulados por Meyer e Schmid (1974), segundo o qual "os distúxbios psíquicos em IAP poderiam estar relacionados com a diminuição de metabóli tos críticos ou acúmulo de substâncias neurotóxicas que embora não estejam diretamente relacionadas à síntese de heme, ${ }^{2}$ podem ser consequência da doença".

Ressaltamos aqui, a importância da contribuição deste tram balho para a elucidação dos mecanismos bioquímicos responsáveis pelas manifestações neuropsĩquicas em indivĩduos portadores de IAP. O desconhecimento, até o momento, de tais mecanismos evidentemente emperra a descoberta de novas terapias para esta ter rìvel doença que aflige grande número de portadores, acarretando muitas vezes sua morte quando entram em crise aguda. Nossos resultados reforçam tambēm as tentativas de correlação entre a formação biológica e utilização de espécies ativas de oxigênio e distúrbios mentais, efetuadas por Michelson e colaboradores (1977) e diversos outros grupos.

5.3. Atividades eritrocitárias de SOD, catalase e GSH-Px de residentes em Vila Parisi (Cubatão, SP) .

Vimos na Introdução que os níveis de SOD em eritrōcitos de parisienses eram cerca de $33 \%$ mais elevados do que de indivíduos 
TABELA 5.2 - Concentrações eritrocitārias de SOD, Catalase e GSH-PX em pacientes com doenças mentais.

\begin{tabular}{|c|c|c|c|c|}
\hline DOENÇA & $\begin{array}{l}\text { SOD } \\
\mu g / g \quad H b\end{array}$ & $\begin{array}{l}\text { GSH }-\mathrm{PX} \\
\mu \mathrm{M} \mathrm{NADPH} / \\
\mathrm{min} / \mathrm{g} \mathrm{Hb}\end{array}$ & $\begin{array}{l}\text { CATALASE } \\
\mu \mathrm{g} / \mathrm{g} \mathrm{Hb}\end{array}$ & REF. \\
\hline Trisomia 21 & $\begin{array}{c}679,4 \pm 62,8 \\
(461,4 \pm 45,8)^{\mathrm{a}}\end{array}$ & $\begin{array}{c}8,89 \pm 1,91 \\
(5,73 \pm 1,54)\end{array}$ & $\left|\begin{array}{rr}3 & 841 \pm 525 \\
(4 & 043 \pm 638\end{array}\right|$ & Michelson e col. (1977) \\
\hline Trisomia 21 & - & $\begin{array}{l}44,2 \pm 7,15 \\
(29,5 \pm 3,55)\end{array}$ & - & Agar e Hingston (1980) \\
\hline $\begin{array}{l}\text { Retardamen- } \\
\text { to mental } \\
\text { não mongo- } \\
\text { löide. }\end{array}$ & - & $\begin{array}{c}35,2 \pm 7,62 \\
(29,5 \pm 3,55)\end{array}$ & - & Agar è Hingston (1980) \\
\hline $\begin{array}{l}\text { Autismo In- } \\
\text { fantil. }\end{array}$ & $\begin{array}{c}537,9 \pm 12,9 \\
(461,4 \pm 18,7)\end{array}$ & $\begin{array}{c}4,7 \pm 0,29 \\
(8,45 \pm 0,95)\end{array}$ & - & Golse è col. (1978). \\
\hline $\begin{array}{l}\text { Psicose Pa- } \\
\text { ranöica. }\end{array}$ & $\begin{array}{l}714 \\
(461,4 \pm 45,8)\end{array}$ & - & $\left.\mid \begin{array}{cc}5 & 872 \\
(4 & 043 \pm 638\end{array}\right)$ & Michelson e col. (1977) \\
\hline $\begin{array}{l}\text { Esquizofne- } \\
\text { nia }\end{array}$ & $\begin{array}{c}504 \pm 682 \\
(461,4 \pm 45,8)\end{array}$ & - & - & Michelson e col. (1977) \\
\hline
\end{tabular}

a. Estão relatados em parênteses os níveis enzimäticos dos indivíduos normais. 
residentes na zona rural da França, enquanto que não se detectou variações em sua atividade catalásica (Michelson e colabora dores, 1977).

Nossos resultados, obtidos na dosagem de SOD, catalase e glutationa peroxidase nos hemolisados de residentes de Vila Parisi, comunidade submetida diariamente a níveis altíssimos de poluição atmosférica, mostraram que:

(i) os níveis de SOD em eritrócitos de residentes de Vila Parisi são cerca de 1,5 vezes maiores que em indivíduos res dentes na cidade de São Paulo (grupo controle). Veja Fig. 5.1.3 e 5.14;

(ii) os niveis de GSH-Px apresentam um aumento de cerca de duas vezes em relação ao controle (Fig. 5.15 è 5.16);

(iii) eritrócitos de residentes em Vila Parisi e são Paulo apresentaram níveis semelhantes de catalase (Fig. 5.17 e 5.18).

Nestes três casos, entretanto, notou-se uma dispersão das medidas individuais numa faixa bem mais ampla que a do controle. Mesmo assim, e considerando o pequeno tamanho da amostra $(n=23)$, a aplicação do teste estatístico de Kolmogorov-Smirnov revelou que os níveis de SOD e GSH-Px em residentes de Vila Parisi são realmente distintos dos níveis destas enzimas no grupo controle, com um nível de significância de 0,05. Tais diferenças refletem claramente profundas alterações metabólicas envolvendo oxigênio na amostra-alvo em relação ao controle.

Certamente, seria interessante aumentar nossa amostragem de Vila Parisi e comparar os resultados com aqueles de morado- 
res de viilas não poluídas do litoral paulista, de residentes de cidades do interior de São Paulo, ou mesmo de individuos residentes na cidade de Cubatão, a qual segundo depoimento do Dr. Ney Éduardo serra, delegado da CIEsp para a região de cubatão (debate promovido pelo jornal "Folha de São Paulo" em 26/10/81), apresenta indices de poluição atmosférica inferiores aos da cidade de são Paulo.

Num trabalho independente, Naoum e colaboradores (comunica ção pessoal), encontraram que 33,98 da população de Cubatão padece de metahemoglobinemia e 35,48 de sulfohemoglobinemia, sendo que em algumas amostras de glóbulos vermelhos foram encontra dos inclusive corpos de Heinz. Por outro lado, segundo Carrel e colaboradores (1975), qualquer fator que leve a um aumento na flexibilidade ou distorção da conformação da hemoglobina, deixando o grupo heme mais exposto, pode resultar em uma elevação na concentração de metahemoglobina e concomitante formação de Ions superóxido. Está atualmente bem estabelecido que diversas moléculas orgânicas, agentes redox e íons de metais de transição tornam a oxihemoglobina mais suscetível à oxidação. Como exemplo, citamos o caso de um antioxidante muito comum em borrachas (N-isopropil-N'-fenil-p-fenilenodiamina) que causa a rāpida oxidação e denaturação de hemoglobina purificada (Williamson e colaboradores, 1981). A formação de espēcies ativas de oxigênio durante a oxidação de hemoglobina é também sustentada por dados de Brunori e colaboradores (1975) que encontraram um aumento na formação de Ion superóxido em talassemias. Neste caso, as cadeias isoladas de hemoglobina são especialmente susceptíveis à oxidação. 
A fig. 5.2. mostra a sequência completa de degradaçäo oxidativa de hemoglobina, proposta por Winterbourn e Carrel (1974), culminando com a precipitação intrahemácias da globina e, posteriomente, hemölise. Este quadro explica de forma notãvel a conexão entre nossos resultados e os dados sobre metahemoglobinemia em moradores de Vila Parisi. Nesta região, hã alta concen tração de poluentes atmosféricos os quais, via associação ou reação química com a hemoglobina das hemácias, alternariam sua conformação resultando no aumento de velocidade de degradação de oxihemoglobina, com produção excessiva de $\mathrm{O}_{2}^{\bar{*}}$. Este seria o sinal para indução da síntese de SOD (Crappo e Tierney, 1974) acarretando um aumento da concentração eritrocitária de $\mathrm{H}_{2} \mathrm{O}_{2}$ $\left(2 \mathrm{O}_{2}^{\bar{j}}+2 \mathrm{H}^{+} \stackrel{\mathrm{SOD}}{\longrightarrow} \mathrm{O}_{2}+\mathrm{H}_{2} \mathrm{O}_{2}\right)$. Esse aumento excessivo de peróxido, por sua vez, induziria a biossintese de GSH-Px em concentrações elevadas (Reddy e Tappel, 1974).

Observou-se também, que os desvios das médias dos dados de dosagens das três enzimas em moradores de Vila parisi são bem maicres que os desvios das médias das atividades enzimáticas do grupo controle. Tal efeito pode estar relacionado com exposições a poluentes de natureza diferentes, dependendo do local de trabalho ou de residência do indivíduo ou então com respostas metabólicas individuais distintas à toxicidade de espécies ativadas de oxigênio.

Ressaltamos aqui a existência de uma possível relação entre os níveis alterados dessas enzimas protetoras e as recentes comunicações à imprensa do Dr. Reinaldo Azoubel do Departamento de Genētica da USP, em Ribeirão Preto, alertando para a existên 


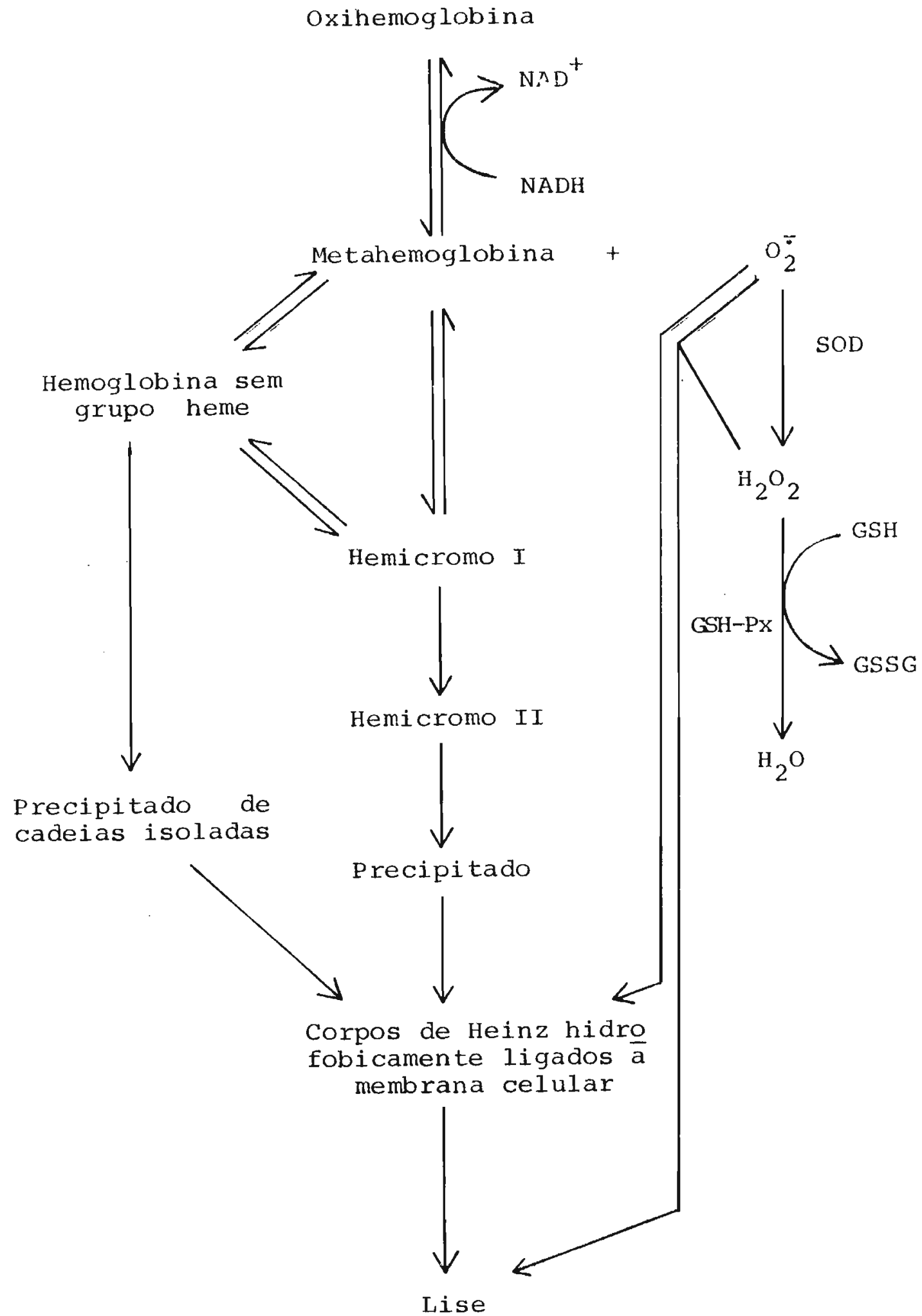

FIGURA 5.2 - Degradação de hemoglobina. 
cia de vários casos de malformações em recém-nascidos (anencefalia, polidactilia, falta de braços e pernas, coluna vertebral dividida, etc.) de Vila Parisi. De fato, dados de Hoffmann e Me neghini (1979) mostraram que irradiação de células humanas com luz visível ou ultravioleta próximo, na presença de uma solução de riboflavina e triptofano e espécies que geram $\mathrm{H}_{2} \mathrm{O}_{2}$ como fotoproduto, provoca quebras de fita simples do DNA. Observaram tambēm que tanto cēlulas humanas normais (VA-13) como uma linhą gem deficiente em reparo de excisão (XP) são sensiveis ao trata mento com baixas concentraçōes de $\mathrm{H}_{2} \mathrm{O}_{2}\left(10^{-6}-10^{-5} \mathrm{M}\right)$, apresentando uma perda da viabilidade reprodutiva em função da concentração. Este trabalho e outros publicados recentemente sobre lesões químicas no DNA, alertam para séria ameaça ao metabolismo celular envolvendo mutagênese e/ou carcinogênese, caso a pro dução de espécies excitadas de oxigênio não esteja sob controle fino no organismo.

Concluindo, nossos resultados indicam distúrbios no metabo lismo de oxigênio em indivíduos residentes em regiões altamente poluidas, oriundos provavelmente de um aumento na velocidade de autoxidação de hemoglobina. Michelson e colaboradores (1977),já haviam notado diferenças nas atividades de SOD em residentes de Paris, contudo não adiantaram nenhuma explicação para estes resultados

O fato dos níveis das enzimas reguladoras do metabolismo de oxigênio estarem elevados tanto em casos de indivíduos com distúrbios psíquicos como em casos de residentes em Vila parisi não estabelece, a princípio, nenhum tipo de correlação entre es 
ses dois grupos, uma vez que nos individuos sujeitos a altos ín dices de poluição, os níveis de SOD e GSH-Px elevados podem sig nificar uma adaptação metabólica eficiente pará terem vida saudُ̈ن 
6. S U M $A$ R I O

A redução univalente de oxigênio molecular nas células pro duz intermediários altamente reativos tais como o ion radical superóxido $\left(\mathrm{O}_{2}^{\bar{*}}\right)$, o radical hidroxil $\left(\mathrm{HO}^{\circ}\right)$ e o peróxido de hidro gênio $\left(\mathrm{H}_{2} \mathrm{O}_{2}\right)$. Níveis muito altos ou baixos de tais espécies representam sēria ameaça ao metabolismo celular. Diferentes estados patológicos têm sido relacionados com níveis anormais destas espēcies em eritrócitos e plaquetas. A proteção biológica contra efeitos tóxicos associados com níveis excessivos de espécies ativadas de oxigênio, tem sido atribuída a três enzimas principais presentes em eritrócitos e outras cêlulas: superöxido dismutase, catalase e glutationa peroxidase.

Neste trabalho, foram feitas dosagens dessas enzimas prote toras em eritrócitos de indivíduos portadores de porfiria aguda intermitente. Esta doença caracteriza-se por um defeito na bios sintese de heme e clinicamente manifesta-se por dor abdominal intensa, paralisia e distürbios neuropsíquicos. Foram encontrados nos pacientes em crise aguda atividades elevadas de superóxido dismutase e de glutationa peroxidase enquanto que a atividade de catalase permaneceu normal. Tais resultados apontam a possibilidade de que as manifestações clínicas de IAP estejam relacionadas com toxicidade por oxigênio.

Comparou-se tambēm a atividade destas trēs enzimas em eritröcitos de residentes na cidade de são Paulo com o de morado- 
res de Vila Parisi, conhecida pelo seu altíssimo nível de polui ção atmosfērica. Os níveis de superóxido dismutase e de glutationa peroxidase são bem mais elevados (cerca de 1,5 vezes) nos individuos residentes em Vila Parisi. A elevação da concentração intracelular destas enzimas pode ser sua resposta ao aumento da taxa de oxidação da oxihemoglobina, a qual é conhecida fonte de Ions superóxido. Estes dados demonstram profundas dife renças no metabolismo de $\mathrm{O}_{2}$ entre esses dois grupos e talvez uma possível adaptação metabólica dos moradores de Vila Parisi aos altos níveis de poluição a que estão expostos. 


\section{SUMMARY}

The univalent reduction of molecular oxygen in cells produces very reactive species such as the superoxide anion $\left(\mathrm{O}_{2}^{\bar{*}}\right)$, the hydroxyl radical $\left(\mathrm{HO}^{\circ}\right)$ and hydrogen peroxide $\left(\mathrm{H}_{2} \mathrm{O}_{2}\right)$. Abnormally high or low concentrations of such species may represent a serious threat to the cellular metabolism. Indeed, several disorders have been associated with abnormal levels of these species in erythrocytes and platelets. The biological protection against toxic effects due to excessive levels of activated species of molecular oxygen has been attributed mainly to three enzymes occurring in erythrocytes and other cells: superoxide dismutase (SOD), glutathione peroxidase (GSH-PX) and catalase.

In the present work, we report the activities of SOD, GSH-PX and catalase in the erythrocytes of patients with intermittent acute porphyria (IAP), an inborn error in the heme biosynthetic pathway. The clinical manifestations of IAP include abdominal pain and neuropsychiatric symptons. In patients undergoing acute attack, we found increased levels of SOD and GSH-PX, while that of catalase remains unchanged. These results point to the possibility that the clinical manifestations of IAP are related to oxygen toxicity.

We have also compared the activities of these enzymes in 
residents of the city of são Paulo (Brazil) and in subjects living in Vila Parisi (Cubatão, SP, Brazil), a village submitted to high levels of atmospheric pollution. The rithrocyte SOD and GSH-Px levels were found to be ca. 1.5 fol. higher in residents of Vila Parisi. These high intracellular enzyme concentrations may reflect a biological defense against an increase in the rate of oxyhemoglobin oxidation, known to be a source of superoxide species. Our results point to important differences between the two populations with respect to the metabolism of oxygen and, perhaps, a metabolic adaptation in the residents of Vila Parisi to the dramatically high levels of atmospheric pollution. 


\section{REFERÊNCIAS BIBLIOGRAFICAS}

Agar, N.S., J.Hingston (1980) Med.J.Aust. 1, 556-557.

Auclair, C., D. Dhermy e P. Boivin (1981) Bull.europ.Physiopath.resp. $17,207-212$.

Ballou, D., G. Palmer e V. Massey (1969) Bioch.s.Biophys.Res.

Commun. $36,898-904$.

Bartoli, G.M., T. Galeotti, G. Palombini, G. Parisi e A. Azzi

(1977) Arch.Biochem.Biophys. 184, 276-281.

Beauchamp, C. e I. Fridovich (1971) Anal.Biochem. 44, 276-287.

Bechara, E.J.H. e G. Cilento (1971) Biochemistry 10, 1831-

1836 .

Beckmann, R. e L. Flohē (1981) Bull.europ.Physiop.resp. 17, $275-286$

Bonkowsky, H.L., A. Collins, J.M. Doherty e D.P. Tschudy (1973) Biochim.Biophys.Acta $320,561-576$.

Boveris, A., N. Oshino e B. Chance (1972) Biochem.J. 128 , 617-630.

Boveris, A., E. Cadenas e A.O.M. Stoppani(1973) Biochem.J. 134, 707-716.

Boveris, A. e E. Cadenas (1975) FEBS Lett. 54, 311-314.

Bozzi, A., I. Mavelli, A. Finazzi, R. Strom, A.M. Woly, B. Mondovi e G. Rotilio (1976) Mol.Cell.Biochem. 10, 11-16. 
Brunori, M., G. Falcioni, E. Fioretti, B. Giardina, G. Rotilio (1975) Europ.J.Biochem. 53, 99-104.

Buettner, G.R., L.W. Oberley, S.W.H.C. Leuthauser (1978) Photochem.Photobiol. 21, 693-695.

Burri, B.J., S.G. Chan, A.J. Berry e S.K. Yarnell (1980) Clin. Chim.Acta 105, 249-255.

Carrell, R.W., C.C. Winterbourn e E.A. Rachmilewitz (1975) Brit.J.Haemato1. $30,259-264$.

Chance, B., H. Sies e A. Boveris (1979) Physiol.Reviews 59, $527-605$.

Chow, C.K. e A.L. Tappel (1972) Lipids 7, 518-524.

Christophersen, B.O. (1969) Biochem.Biophys.Acta 176, 463470 .

Cilento, G. (1980) Acc.Chem.Rev. 13, 225-230.

Cohen, G. e P. Hochstein (1963) Biochemistry 2, 1420-1428.

Cohen, G. e R.E. Heikkila (1977) em "Superoxide and Superoxide Dismutases" eds. A.M. Michelson, J.M. McCord e I. Fridovich, Academic Press, New York, pp. 351-365.

Cotton, M.L. e H.B. Dunford (1973) Can.J.Chem. 51, 582-587.

Crapo, J.D. e D.F. Tierney (1974) Am.J.Physiol. 226, 1401-1407.

Del Villano, B.C., S.I. Miller, L.P. Schacter e J.A. Tischfield (1980) Science 207, 991-993.

Diliberto Jr., E.J. e S. Kaufman (1977) em "Superoxide and Superoxide Dismutases", eds. A.M. Michelson, J.M. McCord e I. Fridovich, Academic Press, New York, pp. 407-408.

Dionisi, O., T. Galeotti, T. Terranova e A. Azzi (1975) Biochim. Biophys.Acta 403, 292-301. 
Drabkin, D.L. e J.H. Austin (1935) J.Biol.Chem. 112, 51-57. Drew, H.D.K. e F.H. Ferman (1937) J.Chem.Soc. 26, 586-592. Dunford, H.B. e J.S. Stillman (1976) Coord.Chem.Rev. 19, $187-251$

Durăn, N., Y. Makita e L.H. Innocentini (1979) Biochem.Biophys. Res. Commun. $88,642-648$.

Emerit, J., J. Loeper, G. Chomette (1981) Bull.europ.Physiopath.resp. 17 (suppl.), 287-288.

Estabrook, R.W., A.G. Hildebrandt, J. Baron, K.J. Netter e K. Leibman (1971) Biochem.Biophys.Res.Commun. 42, 132-139. Estabrook, R.W. e J. Werringloer (1977) em "Tissue Hypoxia and Ischemia", ed. M. Reivich, R. Coburn, S. Lahiri e B. Chance, Plenun, New York, pp. 19-35.

Feigelson, P. e F.O. Brady (1974) em "Molecular Mechanism of Oxygen Activation", ed. O. Hayaishi, Academic Press, New York, pp. 87-133.

Flashner, M.S. e V. Massey (1974) em "Molecular Mechanisms of Oxygen Activation", ed. O. Hayaishi, Academic Press, New York, pp. 245-280.

Flohé, L. (1979) em "Oxygen Free Radicals and Tissue Damage". ed. Ciba Foundation, New York, pp. 95-113.

Flohé, L. e W. Schlegel (1971) Physiol.Chem. 352, 1401-1410. Flohē, L. e R. Zimmernann (1974) em "Glutathione", eds. L. Flohē, H.Ch. Benöhr, H. Sies, H.D. Waller e A. Wendel, Georg Thieme, Stuttgart, pp. 245-260. 
Fridovich, I. (1972) Acc.Chem.Res. 5, 321-326.

Fridovich, I. (1974) em "Molecular Mechanisms of Oxygen Activation", ed. O. Hayaishi, Academic Press, New Yoxk, pp. 453477 .

Fridovich, I. (1975) Annu.Rev.Biochem. 44, 147-159.

Fridovich, I. (1977) em "Biochemical and Medical Aspects of Active Oxygen", ed. O. Hayaishi e K. Asada, University Park Press, Tckyo, pp. 171-181.

Fridovich, I. (1979) em "Advances in Inorganic Biochemistry", eds. G.L. Eichhorn e L.G. Marzili, Elsevier/North Holland, New York, pp. 67-90.

Foote, C.S. (1976) em "Free Radicals in Biology", ed. W.A. Pryor, Academic Press, New York, vol. II, pp. 85-133.

Foote, C.S., F.C. Shook, R.A. Abakerli (1980) J.Am.Chem.SoC. $102,2503-2504$.

Gerli, G.C., L. Beretta, M. Bianchi, A. Pellegatte e A. Agostori (1980) Scand.J.Haematol. 25(1), 87-92.

Goldgerb, B. e A. Stern (1976) J.Biol.Chem. 251, 6468-6470.

Goldberg, A., M.J. Brodie e M.R. Moore (1978) em "Porphyrin Metabolism and the Porphyrias" ed. Bodley-Scott, R., Oxford University Press, pp. 420-425.

Goldstein, I.M., D. Ross, H.B. Kaplan e G. Weissmann (1975) J.Chim. Invest. $\underline{56}, 1155-1163$.

Golse, B., P. Debray-Ritzen, P. Durosay, K. Puget e A.M. Miche1son (1978) Rev.Neurol. 134, 699-705.

Gregory, E.M. e I. Fridovich (1973) J.Bacteriol. 114, 1193-1197. 
Gregory, E.M., S.A. Goscin e I. Fridovich (1974) J.Bacteriol. 117, 456-460.

Gryglewski, R.J., S. Bunting, S. Moncada, R.J. Flower e J.R. Vane (1976) Prostaglandins 12, 685-713.

Guiraud, H.J. e C.S. Foote (1976) J.Am.Chem.Soc. 98, 19841986 .

Halliwell, B. (1978) em "Age Pigments", ed. R.S. Sohal, Elsevier/North-Holland, New York.

Halliwel1, B. (1978a) FEBS Lett. 92, 321-326.

Halliwell, B. (1978b) Cell.Biol.Int.Rep. 2, 113-128.

Halliwell, B. (1981) Bull.europ.Physiopath.resp. 17, 21-28. Harmn, D. (1971) J.Geront. 26, 451-457.

Hartz, J.W., S. Funakoshi e H.F. Deutsch (1973) Clin.Chim. Acta $46,125-132$.

Hassan, H.M. e I. Fridovich (1977) J.Bacteriol. 129, 15741583 .

Hildebrant, A.G. e I. Roots (1975) Arch.Biochem.Biophys. 171, $385-397$.

Hinckle, P.C., R.A. Britow, E. Racker e B. Chance (1967) I. Biol.Chem. 242, 5169-5173.

Hirata, F. e O. Hayaishi (1972) Biochem.Biophys.Res.Commun. 47, 1112-1119.

Hirata, F. e O. Hayaishi (1977) em "Superoxide and Superoxide Dismutases", eds. A.M. Michelson, J.M. McCord e I. Fridovich, Academic Press, New York, pp. 395-406. 
Hoffmann, M.E. e R. Meneghini (1979) Photochem.Photobiol. 29, 299-303.

Jacobs, M.M., B. Jansson E A.C. Griffin (1977) Cancer Lett. 2. 133-137.

Jensen, P.K. (1966) Biochem.Biophys.Acta 122, 157-166.

Johnston, R.B. e J.E. Lehmeyer (1977) J.Clin.Invest. 57, 836841 .

Kearns, D.R. (1971) Chem.Rev. 71, 395-427.

Lazarow, P.B. e C. De Duve (1976) Proc.Nat1.Acad.Sci.USA 73, 2043-2046.

Little, C. e P.J. O'Brien (1968) Biochem.Biophys.Res.Commun.

$31,145-150$.

Liu, T.z., J.T. Shen e W.F. Ganong (1974) Proc.Soc.Exp.Bio Med. 146,37 .

Lynch, R.E. e B.C. Cole (1980) Biochem.Biophys.Res.Commun. $96,98-105$.

Maral, J., K. Punget e A.M. Michelson (1977) Biochem.Biophys. Res.Commun. 77, 1525-1535.

Marver, H.S. e R.C. Schmid (1972) em "The Metabolic Basis of Inherited Disease", eds. J.B. Stanbury, J.B. Wyngoarden e D.S. Frederickson, McGraw-Hi11, New York, p. 1057.

Massey, V., S. Strickland, S. Mayhew, L. Howell, P. Engel, R. Matthews, M. Schuman E P. Sullivan (1969) Biochem.Biophys. Res.Commun. 36, 891-897.

McCord, J.M. e I. Fridovich (1968) J.Biol.Chem. 243, 5753-5760. 
McCord, J.M. e I. Fridovich (1969) J.Biol.Chem, 25, 6049-6055. McCord, J.M. e E.D. Day (1978) FEBS Lett. 86, 139-142.

Meyer, U.A. e R. Schmid (1974) em "Brain Dysfunction in Methabolic Disorders", ed. F. Plum, vol. 53, Raven Press, New York, pp. 211-224.

Michelson, A.M. (1977) em "Biochemical and Medicah Aspects of Active Oxygen", ed. O. Hayaishi e K. Asada, University Park Press, Tckyo, pp. 155-168.

Michelson, A.M., K. Puget, P. Durosay e J.C. Bouneau (1977), em "Superoxide and Superoxide Dismutases", ed. A.M. Michelson, J.M. McCord e I. Fridovich, Academic Press Inc., London, pp. $467-499$.

Miller, R.W. e U. Rapp (1973) J.Biol.Chem. 248, 6084-6090. Mishin, V., A. Pokrovsky e V.V. Lyabovich (1976) Biochem.J. $154,307-310$.

Misra, H.P. e I.Fridovich (1972) J.Biol.Chem. 247, 6960-6962. Miyagi K., R. Cardinal, I. Bossinmaier e C.J. Watson (1971) J.Lab.clin.Med. 78, 683-695.

Moore, M.R., E.L. Kenneth e A. Goldberg (1980) Int.J.Biochem. $12,941-946$.

Morrison, M., P.Z. Allen, J. Bright and W. Jayasinghe (1965) Arch.Biochem.Biophys. 111, 126-133.

Morroka, Y., P.J. Chung, H. Arakawa e T. Ikawa (1976) Chem. Lett. 1293-1296.

Nicholls, P. e G.R. Schombaum (1963) em "The Enzymes", ed. P.D. Boyer, H. Lardy e K. Myrback, vol. 8, 2nd., p: 147. 
Nishinaga, A. (1977) em "Biochemical and Medical Aspects of Active Oxygen", ed. O. Hayaishi e K. Asada, University Park Press, Tokyo, pp. 13-27.

Niwa, T., H. Yamaguchi e K. Yana (1977) em "Biochemical Medical Aspects of Active Oxygen", ed. O. Hayaishi e K. Asada, University Park Press, Tokyo, pp. 209-222.

Norrod, P. e S.A. Morse (1979) Biochem.Biophys.Res.Commun. $\underline{101}, 1026-1031$.

Oberley, L.W. e R.G. Buettner (1979) Cancer Research 39 , $1141-1149$.

Okahata, S., Y. Nishi, S. Hatano, Y. Kobayashi e T. Usui (1980) Eur.J.Pediatr. 134, 121-124.

Omaye, S.T., S.L. Taylor, J.W. Forstrom e A.L. Tappel (1975) Fed.Proc. 34, 538 .

Orrenios, S. e L. Ernster (1974) em "Molecular Mechanisms in Oxygen Activation", ed. O. Hayaishi, New York Academic, pp. $215-244$.

Oshino, N. e B. Chance (1977) em "Biochemical and Medical Aspects of Active Oxygen", ed. O. Hayaishi e K. Asada, University Park Press, Tokyo, pp. 191-204.

Packer, L. e K. Fuehr (1970) Lab.Invest. 23, 86-92. Packer, L. e J.R. Smith (1974) Proc.Nat.Acad.Sci., wash. 71, $4763-4767$.

Reddy, K. e A.L. Tappel (1974) J.Nutr. 104, 1069-1078. Rigo, A., R. Stevanato, A. Finazzi-Agro e G. Rotilio (1977) FEBS Lett. 80, 130-132. 
Rister, M., K. Bauermeister, U. Gravert e E. Gladtke (1979) Eur.J.Pediatr. $130,127-136$.

Ross, D. e R.S. Weening (1979) em "Oxygen Free Radicals and Tissue Damage", ed. Ciba Foundation, New York, pp. 225-254. Rowland, L.P. (1976) Arch.Neurol. 33, 315-321.

Salin, M.I. e J.M. McCord (1974) J.Clin.Invest. 54, 1005-1009. Saunders, B.C., A.G. Holmes-Siedle e B.P. Stark (1964) "Peroxidase", Washington, DC: Butterworths.

Schombaum, G.R. e B. Chance (1976) em "The Enzymes", 2a.ed., ed. F.D. Boyer, Academic Press, New York, pp. 363-408.

Schrauzer, G.N., D.A. White e C.J. Schneider (1977) Bioinorg. Chem. 7, 23-34.

Shamberger, R.J. (1976) em "Proceedings of the symposium on Selenium-Tellurium in the Environment", ed. Industrial Health Foundation, Inc. ; Pittsburgh, pp. 253-267.

Sies, H. (1974) Angew.Chem.Int.Ed.Engl. 13, 706-718. Strand, L.J., U.A. Meyer, B.F. Felsher, A.G. Redicker e H.S. Marver (1972) J.Clin.Invest. 51, 2530-2536.

Sutton, H.C., P.B. Roberto e C.C. Winterbourn (1976) Biochem. J. $15 \underline{5}, 503-510$.

Tschudy, D.P., M. Valsamis e C.R. Magnusseu (1975) Ann.Internal Med. 83, 851-864.

Tyler, D.D. (1975) Biochem.J. 147, 493-504. Ueda, K. e M. Ogata (1978) Acta Med. Okayama 32, 1393-1397. Van Den Brerk, H.A.S. E D. Jamieson (1964) Biochem.Pharmacol. $13,165-182$. 
Vanneste, W.H. e F. Zuberkinler (1974) em "Molecular Mechanisms of Oxygen Activation", ed. Usamu Hayaishi, Academic Press, New York, pp. 371-399.

Xifra, E.A.W., A.M.C. Batlle, A.M. r+ella e S. Malamud (1980) Int.J.Biochem. 12, 819-822.

Yamazaki, I. (1974) em "Molecular Mechanisms of Oxygen Activation", ed. Osamu Hayaishi, Academic Press, New York, pp. 535554.

Williamson, D., C.C. Winterbourn, W.H. Swallow e A.W. Missen (1981) Hemoglobin 5, 73-84.

Wilson, T. (1976) em "Chemical Kinetics", série 2, ed. D.R. Herschbach, M.T.P. Int.Rev.Sci., Butterworth, London, p. 265 . Winterbourn, C.C. e R.W. Carrel (1974) J.Clin.Invest. 54, $678-689$.

Wood, J.D. e G.F. Perkins (1970) Aerosp.Med. 41, 869-872.

Zakowski, J.J. E A.L. Tappel (1978) Biochim.Biophys.Acta $\underline{526}$, $65-76$. 